San Jose State University

SJSU ScholarWorks

Master's Theses

Master's Theses and Graduate Research

1995

\title{
A comparative study between selected sacred double-choir motets of Hans Leo Hassler and Giovanni Gabrieli
}

Mark David Swope

San Jose State University

Follow this and additional works at: https://scholarworks.sjsu.edu/etd_theses

\section{Recommended Citation}

Swope, Mark David, "A comparative study between selected sacred double-choir motets of Hans Leo Hassler and Giovanni Gabrieli" (1995). Master's Theses. 1034.

DOI: https://doi.org/10.31979/etd.reeb-8b47

https://scholarworks.sjsu.edu/etd_theses/1034

This Thesis is brought to you for free and open access by the Master's Theses and Graduate Research at SJSU ScholarWorks. It has been accepted for inclusion in Master's Theses by an authorized administrator of SJSU ScholarWorks. For more information, please contact scholarworks@sjsu.edu. 


\section{INFORMATION TO USERS}

This mamscript has been reproduced from the microfilm master. UMI films the text directly from the original or copy submitted. Thus, some thesis and dissertation copies are in typewriter face, while others may be from any type of computer printer.

The quality of this reproduction is dependent upon the quality of the copy submitted. Broken or indistinet print, colored or poor quality illustrations and photographs, print bleedthrough, substandard margins, and improper alignment can adversely affect reprocuction.

In the unlikely. event that the anthor did not send UMI a complete mamscript and there are missing pages, these will be noted. Also, if unauthorized copyright material had to be removed, a note will indicate the deletion

Oversize materials (e.g, maps, drawings, charts) are reproduced by sectioning the original, beginning at the upper left-hand comer and contiming from left to right in equal sections with small overlaps. Each original is also photographed in one exposure and is included in recuced form at the back of the book

Photographs inchuded in the original mamscript have been reproduced xerographically in this copy. Higher quality $6^{\prime \prime} \times 9^{\prime \prime}$ black and white photographic prints are available for any photographs or illustrations appearing in this copy for an additional charge. Contact UMI directly to order.

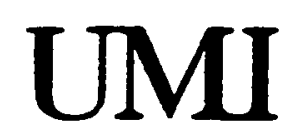

A Bell \& Howell Information Company 300 North Zeeb Road. Ann Afbor. MI 48106-1346 USA $313: 761-4700 \quad 800: 521-0600$ 



\title{
A COMPARATIVE STUDY BETWEEN SELECTED SACRED DOUBLE-CHOIR MOTETS OF HANS LEO HASSLER AND GIOVANNI GABRIELI
}

\author{
A Thesis \\ Presented to \\ The Faculty of the School of Music \\ San Jose State University \\ In Partial Fulfillment \\ of the Requirements for the Degree \\ Master of Arts
}

\author{
by \\ Mark David Swope \\ May 1995
}


UMI Number: 1374625

JMI Microform 1374625

Copyright 1995. bY UMI Company. All rights reserved.

This microform edition is protected against unauthorized copying under Title 17, United States Code.

\section{UMI}

300 North Zeeb Road

Ann Arbor, KI 48103 
(C) 1995

Mark David Swope

ALL RIGHTS RESERVED 


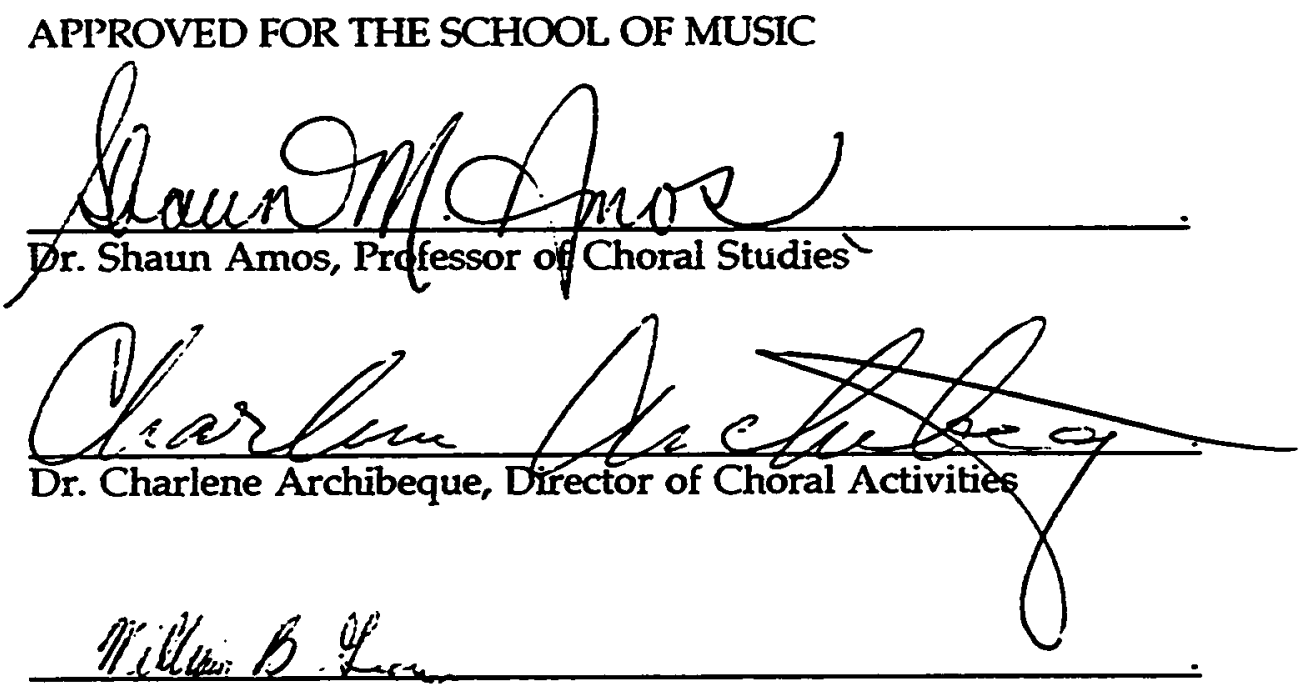

Dr. William George, Graduate Studies Advisor

APPROVED FOR THE UNIVERSITY

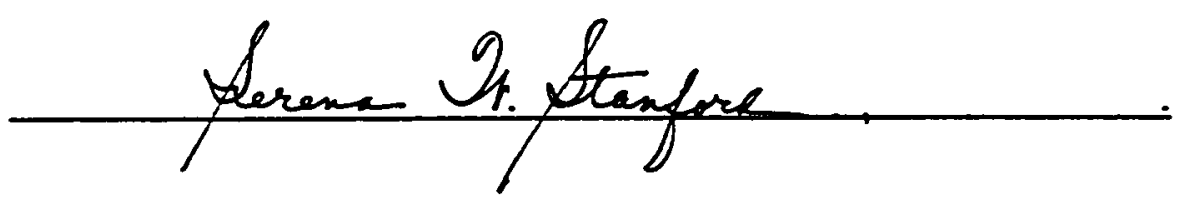




\title{
ABSTRACT \\ A COMPARATIVE STUDY BETWEEN SELECTED SACRED DOUBLE-CHOIR MOTETS OF HANS LEO HASSLER AND GIOVANNI GABRIELI
}

\author{
by Mark $D$. Swope
}

In order to better understand the double-choir compositions of Hans Leo Hassler, this thesis compares selected sacred double-choir motets of this German composer and organist to those of the more widely recognized Italian composer Giovanni Gabrieli. Biographical sketches of each composer, a short history of polychoral compositions, and an outline of compositional and performance practices of double-choir selections provide basis for comparison. Finally, six double-choir compositions-three by each composer based on similar texts-are analyzed: Angelus ad Pastores, Beati Omnes, and Jubilate Deo.

Research analysis of the scores of Hans Leo Hassler and Giovanni Gabrieli reveal the innovative tendencies of both composers. Hassler's double-choir compositions further demonstrate his command of High Renaissance compositional techniques as well as his ability to incorporate the teachings of his Italian mentors Giovanni and Andrea Gabrieli into his polychoral works. 


\section{CONTENTS}

Chapter

Page

List of Examples......................... vii

1. Introduction $\ldots \ldots \ldots \ldots \ldots \ldots \ldots \ldots \ldots \ldots \ldots \ldots \ldots \ldots \ldots \ldots$

Statement of the Problem................... 2

Organization and Limitations................. 3

II. A History of Polychoral Compositions............... 5

III. Composition and Performance Practices............. 11

Composition..........................11

Performance........................... 14

IV. Giovanni Gabrieli.......................... 16

Life.................................

Works and Influences....................17

V. Hans Leo Hassler............................ 20

Life................................20

Works and Influences....................21

VI. Angelus ad Pastores..........................24

VII. Beati Omnes...............................34

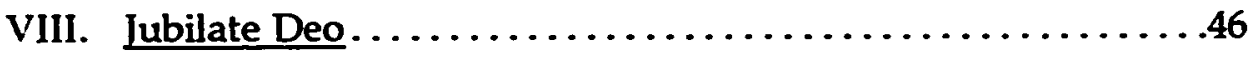

IX. Conclusion ............................... 53

Selective Bibliography........................ 55

Appendices.................................. 65

A. Text Translations...................65

B. Graphic Analyses...................70

C Angelus ad Pastores a12 -Giovanni Gabrieli...76 


\section{CONTENTS}

\section{Appendices continued}

D. Angelus ad Pastores a9-Hans Leo Hassler.....91

F. Beati omnes a8 -Giovanni Gabrieli......... 103

F. Beati omnes a8 -Hans Leo Hassler..........113

G. Iubilate Deo a8 -Giovanni Gabrieli......... 125

II. Iubilate Deo a8 -Hans Leo Hassler.......... 137 


\section{LIST OF EXAMPLES}

Example

1. Measures 13-14 from "Gay Little Nymph" by

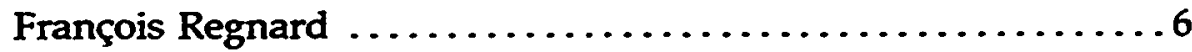

2. Measures 1-4. "Boruch" Arranged by Lichtenstein-

Lewandowski................................. 7

3. Measures 9-11. Short Phrase and Dotted Rhythm..........25

4. Measures 18-22. Longer Flowing Phrase.............. 26

5. Measures 26-29. Rhythm and Short Phrases of Both Choirs... 26

6. Measures 1-2. Imitative Entrance.....................29

7. Measures 12-13. Choir II Enters and Choir I Candences.......29

8. Measures 18-19. Anticipation by Choir Il...............30

9. Measures 1-3. Extended Phrasing and Long Note Values......34

10. Measure 10. Use of Shorter Note Values................35

11. Measures 13-15. Psalm 128:2 Interupted at Measure 14 with

New Theme, Texture and Rhythm...................36

12. Measures 21-23. Continuing Text and New Music........... 37

13. Measures $32-37$. Text Painting.................... 42

14. Measures 39, 44, 46, 48-50. Progression Toward Antiphonal

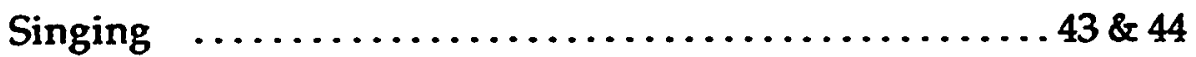

15. Measures 6-8. Text Painting.....................47

16. Measures 29-32. Demonstrating the Complexities of

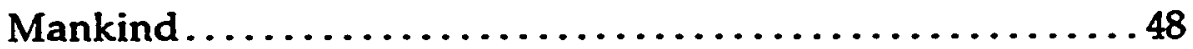

17. Short Phrases and Quick Note Values................ 49

18. Measures 15-16. Longer Note Values................50 


\section{Chapter 1}

\section{Introduction}

The lives and music of Hans Leo Hassler and Giovanni Gabrieli are intertwined through common experiences and teachers. As a young choirboy Hassler worked with Friedrich Lindner, the cantor at St. Egidien in Nuremberg. It is possible that Lindner had been a student of Orlandus Lassus, as was Giovanni Gabrieli. Lindner, though fully versed in German methods of composition, can be considered an advocate of the Italian style. "...His volumes of works by Italian masters--including Giovanni Palestrina (c.15251594), Tarquinio Merula (c.1590-1665), Luca Marenzio (1553-1599), Orazio Vecchi (1550-1605), and Andrea Gabrieli (c.1515-1586)- represent the largest collection of Italian music available in Germany at the time." 1 Similarly, Giovanni Gabrieli became educated in the Germanic style of composition from Orlandus Lassus while living in Munich with his uncle Andrea from c. 1573 to c. $1583^{2}$. In 1584 it was then Hassler who traveled from Germany to Venice where he studied with the Gabrielis for fifteen to eighteen months.

The sacred double-choir motets of Hans Leo Hassler and Giovanni Gabrieli contain scoring for a wide range of vocal forces, simple harmonic progressions which foreshadow Baroque tonicization and innovative compositional techniques which formulate music representative of the High

'John Hoffacker, "Hassler and the Italian Style," The Choral Journal $31 / 2$ (Spring 1989): 9.

2Due to a lack of documentation the exact dates of Gabrieli's stay in Munich are unknown. He may have returned to Venice anytime between $\mathbf{1 5 8 0}$ and 1584. 
Renaissance. These and other similarities can be discovered through a study of their sacred cori spezzati ${ }^{3}$ (i.e. split choir) compositions.

Differences between the two composers in style, texture, timbre and use of thythmic and melodic devices exist as well. By exploring these comparisons one is able to identify the individual contributions each made to the development of double-choir compositional techniques. The result is the recognition of the mature polychoral compositions of Hans Leo Hassler as equally substantial works when compared to those of the more well known Giovanni Gabrieli.

\section{Siatement of the Problem}

Giovanni Gabrieli developed a high standard of antiphonal composition which other European composers tried to emulate. His position as organist at St. Mark's Basilica in Venice, a recognized music center in the late 16th and early 17th centuries, brought attention to his accomplishments as a composer of cori spezzati works. Hans Leo Hassler was one of the many musicians who acknowledged the importance of, and was influenced by, the music being produced in Venice. Hassler eventually travelled to Venice to study with Andrea Gabrieli (Giovanri's uncle) and became a good friend of Giovanni.

\footnotetext{
${ }^{3}$ Cori spezzati: a polychoral work or passage. The ensemble is consistently split into two or more groups, each retaining its own identity, which sing separately and together within a through-composed framework in which antiphony is a fundamental compositional resource; in tutti passages all voice-parts should normally remain independent, with the possible exception of the bass parts. Anthony Carver, Cori Spezzati. Volume I: The Development of Sacred Polychoral Music to the Time of Schütz, (Cambridge: Cambridge University Press, 1968), p. xvi.
} 
The double-choir motets of both Giovanni Gabrieli and Hans Leo Hassler demonstrate a thorough understanding of generally accepted compositional techniques particular to their region (Germany and Venice respectively). However, the progressive tendencies and innovaions of these two composers took them beyond the teachings of their mentors and expanded generally accepted practices of composition to include new textural extremes, harmonies and dissonances. Hassler's double-choir motets are comparable to those of Gabrieli in character (per their mutual teacher Andrea Gabrieli), creativity (making use of compositional techniques not previously explored), and musicality (demonstrating a mastery of phrasing, continuity, vocal balance and proportions). Therefore, a comparative study between the polychoral music of Giovanni Gabrieli-who has been identified by music historians as the perfector of cori spezzati composition-and Hans Leo Hassler-a master of the style in his own region-is much needed. Through this study the author intends to provide a basis for understanding the doublechoir motets of Hans Leo Hassler.

\section{Organization and Limitations}

This document first provides a foundation upon which comparisons between Hans Leo Hassler and Giovanni Gabrieli can be drawn. A summary of the historical development of cori spezzati is provided. Cori spezzati performance and compositional techniques in use between 1580 and 1612 are outlined. A biographical sketch of the lives of Hassler and Gabrieli is provided, including information on major influences and compositions. Finally, an analysis of three typical cori spezzati compositions based on 
similar texts by each composer is made. Those texts-Angelus ad Pastores, Beati Omnes, and Jubilate Deo-can be found with their translations in Appendix A. From the historical, theoretical and analytical information provided, the compositions already mentioned are compared for similarities and differences.

In order to establish a thorough comparison of Hans Leo Hassler's and Giovanni Gabrieli's double-choir motets, it would be necessary to analyze their entire double-choir repertory. Only three double-choir motets of Hassler and Gabrieli will be analyzed and compared in this document. These compositions feature compositional techniques which are standard for the works of Giovanni Gabrieli and Hans Leo Hassler, and being typical may serve as a starting point for future analyses of other similar works. Conclusions of this study could be used as a basis for further studies. 
Chapter 2

\section{A History of Polychoral Compositions}

Venetian composers, and more specifically those affiliated with St. Mark's Basilica, were once credited with the creation of polychoral uriting. The addition of a second organist and possibly a second organ at St. Mark's in 1490 made the division of choirs physically and musically possible. However, there is no evidence to substantiate the use of both organs-and the multiple choir lofts-for the purpose of singing polychoral compositions at St. Mark's. The presence of two organs in the Basilica was not unique for 1490 . "St. Antony's in Padua also had two (organs) from about 1490" and "Milan Cathedral had two organs from about 1466."4 Adrian Willaert (1480-1562)the basilica's maestro di cappella from 1527-1562-contributed to St. Mark's reputation as the place of origin for double-choir composition. In the 1550 collection Willaert contributed eight salmi spezzati (i.e. split psalms), the first known to be published.

Notwithstanding the information above, the origin of cori spezzati cannot be attributed to the thriving musical center of Venice, as many scholars once believed. Elements of multiple choir compositions can be found in the 15th century Flemish canon, secular dialogues and liturgical antiphons. The division of voices in the Flemish canon implies an awareness of splitting choirs. Canons and other imitative compositions make use of the dux (the leading voice) and comes (responding voice). When rests

\footnotetext{
${ }^{4}$ Anthony Carver, Cori Spezzati. Volume I: The Development of Sacred Polychoral Music to the Time of Schürz (Cambridge: Cambridge University Press, 1988), p. 1.
} 
separate the dux and comes of a liemish canon, a double-choir texture is the result.

$\Lambda$ similar double-choir effect is creaied in madrigal dialogues (secular compositions using texts which contain conversations between characters) when the ensemble is divided to portray the protagonists. 5 Polychoral madrigals which are not dialogues also exist and are referred to as "polychoral chansons" by $\Lambda$ nthony Carver. Both forms can be found in the body of early 16th century choral literature (Example 1).

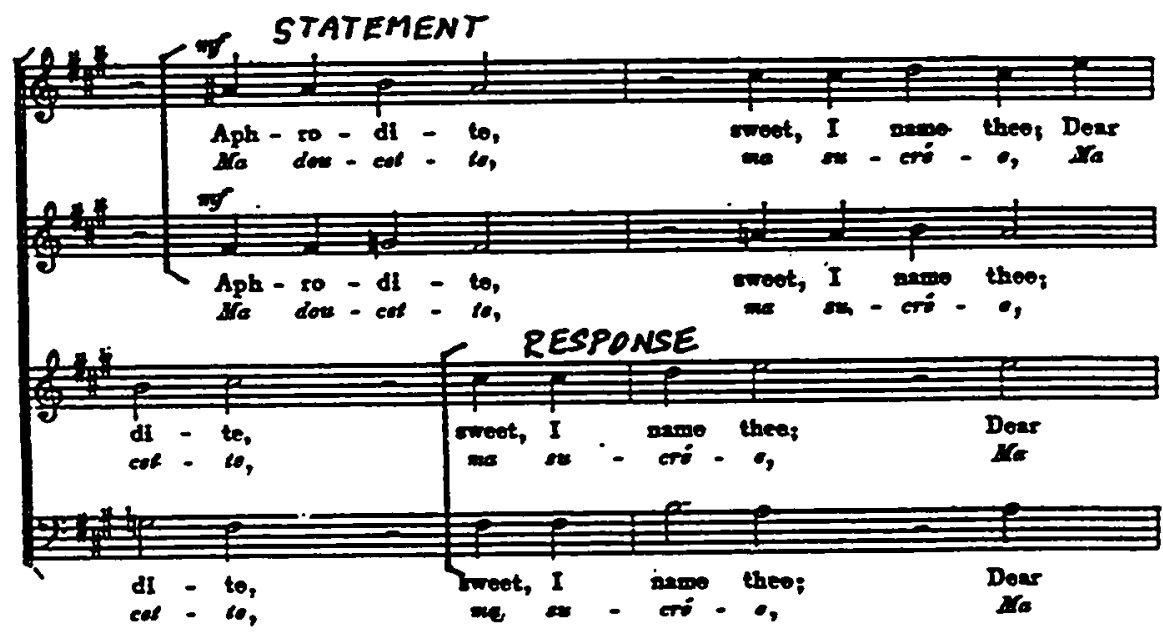

Ex. 1. Measures 13-14 from "Gay Little Nymph" by François Regnard (16th Century). 6

The singing of psalms using alternating statements and responses by two separate groups (i.e. two choirs, or cantor and choir) otherwise known as

5Anthony Carver, "Polychoral Music: A Venetian Phenomenon?," Royal Musical Association Proceedings 108 (1981-1982): 2.

G1. Clough-Leighter, ed., The A Cappella Singer "Gay Little Nymph" by Françcois Regnard. (Boston: E. C. Schirmer Music Company, 1936), p. 118. 
antiphonal psalmody, is another predecessor of cori spezzati to be mentioned. This method of reciting psalms has roots reaching back to the Jewish traditions of Biblical times and was later incorporated into Christian liturgy (Example 2).

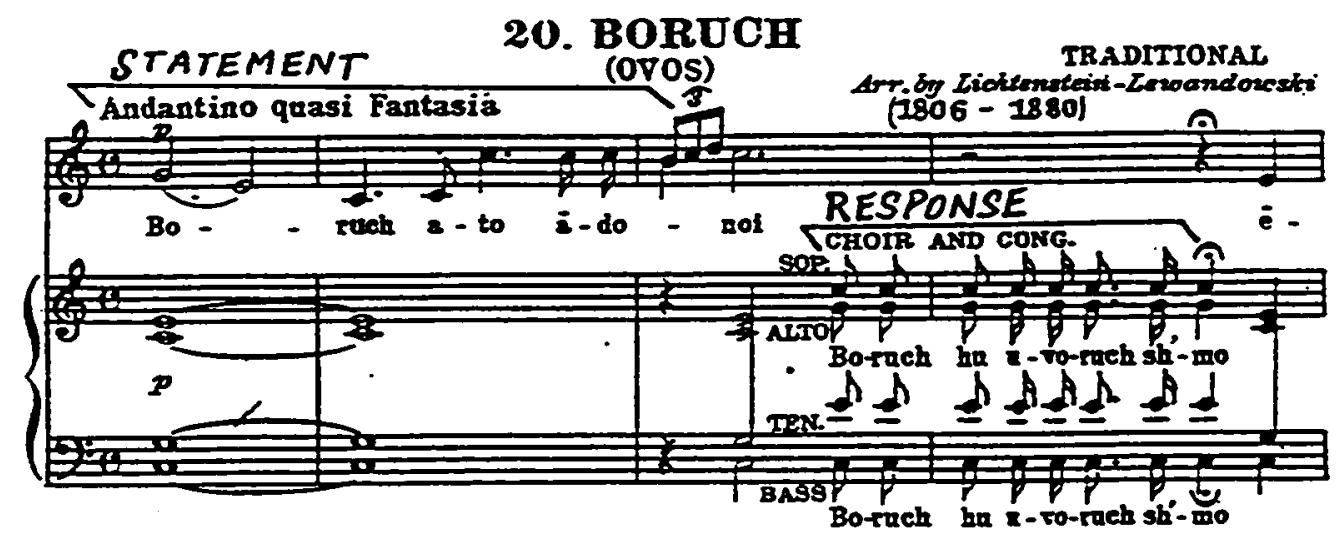

Ex. 2. Measures 1-4. "Boruch" Arranged by LichtensteinLewandowski. ${ }^{7}$

The early development and acceptance of antiphonal and responsive singing in the Roman Catholic Mass is seminal to the later approval of polychoral singing during worship.

While these predecessors contributed to the development of polychoral composition, in most cases they were not themselves polychoral. In some way each lacked a characteristic of polychoral composition as it is commonly defined:

A polychoral work or passage is one in which the ensemble is consistently split into two or more groups, each retaining its

${ }^{7}$ Gershon tiphros, Cantorial Anthology of Traditional and Modern Synagogue Music "Boruch" arranged by Lichtenstein-Lewandowski. Volume 1. (New York: Bloch Publishing Company, 1946), p. 41. 
own identity, which sing separately and together within a through-composed framework in which antiphony is a fundamental compositional resource; in tutti passages all voiceparts should normally remain independent, with the possible exception of the bass parts. 8

Salmi spezzati, published in $\mathbf{1 5 5 0}$ as Di adriano et di Jachet: I salmi appertinenti alli Vesperi...a duoi chori, by Willaert is the only evidence of polychoral composition in Venice prior to Andrea and Giovanni Gabrieli. While this collection was believed by many to establish the origins of cori spezzati, this belief is now known to be false. It is possible to identify fully polychoral compositions outside of Venice prior to 1550 (the year in which Willaert was originally credited for founding cori spezzati ). "The composer uhose work above all seems to demonstrate that before 1550 polychoral techniques were highly developed, and not restricted to Venice, is Dominique Phinot."9 Although Phinot only composed five double-choir motets, they are reprinted in several important German anthologies and "are realiy the first mature examples of the (polychoral) style."10 All of Phinot's double-choir motets can be found in the Thesaurus inusicus published by Montanus and Neuber in 1564. This publication contains fifteen polychoral works in all and brought recognition to the polychoral style as a standard texture.

More examples of the development of polychoral styles outside of Venice exist. In Treviso, Italy, double-choir works were performed under Francesco Santacroce's direction for Vespers and Requiem Masses in 1521,

${ }^{8}$ Anthony Carver, Cori Spezzati. Volume I: The Development of Sacred Polychoral Music to the Time of Schütz, xvi.

9Anthony Carver, "Polychoral Music: A Venetian Phenomenon?", p. 8.

10Anthony Carver, Cori Spezzati. Volume I: The Development of Sacred Polychoral Music to the Time of Schuitz, p. 59. 
1522 and 1523. Psalms and Magnificats for split choirs were performed by Gasparo Alberti and his cappella at the Crociferi in Bergamo in 1536.11 Carver states that the first reference to [cori spezzatil compositions from outside of Venice is Morale's application to maestro de capilla at Toledo Cathedral in 1545 where candidates were required to write an Asperges me, Domine for double-choir. 12 Polychoral compositional techniques began to be codified by the theorists Nicolá Vicentino (1511-1572) and Gioseffo Zarlino (1517-1590) who published separaie treatises: L'antica musica ridotta alla moderna prattica (1555) and Le Institutioni harmoniche (1558) respectively. Thesaurus musicus, a collection of single and double-choir works, was printed by Montanus and Neuber in Nuremburg (1564) and assisted in the establishment of double-choir compositions as a standard idiom in Germany. This collection contains single choir and double-choir compositions by Franco-Flemish composers Orlandus Lassus (1532-1594) and Dominicus Phinot (c.1510-c.1555), and by the Italian composer Antonio Scandello (15171580). Andrea Gabrieli's first polychoral work is dated 1568. In the same year Pietro Giovanelli published a large collection of multi-voiced music which included the first two polychoral motets by Andrea Gabrieli to be published, Lucide ceu fuloo (a8) and Deus misereatur nostri (\$12).

Though the earliest examples of polychoral composition originated outside of Venice, the later success of cori spezzati at Venice led to its eventual popularity throughout Europe. Venice has been credited with cultivating and nurturing this musical form to perfection in the setting of St.

${ }^{11}$ Anthony Carver, Cori Spezzati. Volume I: The Development of Sacred Polychoral Music to the Time of Schütz, p. 3.

12 Ibid., p. 3. 
Mark's Basilica. There, composers such as Adrian Willaert and his pupil Andrea Gabrieli-appointed organist in 1566-began to expand the dimensions of antiphonal liturgy settings prior to the arrival of Giovanni Gabrieli and Hans Léo Hassler by utilizing both organs and, eventually, all three choir lofts. The pinnacle of realizing cori spezzati compositional potential prior to the Baroque era occurred between 1587 (the year Gabrieli's first polychoral compositions were published) and 1612 (the year in which Gabrieli and Hassler died), and is exemplified in the works of Giovanni Gabrieli and Hans Leo Hassler. 


\section{Chapter 3}

\section{Composition and Performance Practices}

\section{Composition}

Between 1550 and 1610 cori spezzati was diverse in its function and was applied to: parts of the Mass Ordinary (rarely the proper), psalms, magnificats and other canticles, litanies, German sacred songs (liturgical and non-liturgical), occasional music (weddings, festivals and celebrations) and motets. The Renaissance motet is defined as a polyphonic setting of a sacred Latin text consisting of three to four voices and utilizing isorhythm. 13 Its liturgical origins, however, did not limit its use:

In the past, scholars sought to identify the Liturgical assignment of a particular motet text on the assumption that the motet was performed as part of the Liturgy. The most recent evidence ${ }^{14}$ suggests, however, that motets served a paraliturgical function as an ornament to the Liturgy, not an essential part of it. Furthermore, the motet was part of the musical entertainments at the princely establishments where so many of the composers earned their livings. 15

Thematic repetition, which pleased musically untutored nobility, was a simple way to achieve unity in double-choir compositions. Extraordinary intervals were often used for text painting in Renaissance motets. Other tools vere used as well: canon, ostinato, paraphrase, ornamentation and imitation.

13 Stanley Sadie, ed. The New Grove Dictionary of Music and Musicians "Hans Leo Hassler" (Washington D. C.: Grove's Dictionaries of Music lnc., 1980), p. 510 .

${ }^{14}$ For further discussion see Anthony Cummings, "Toward an Interpretation of the Sixteenth-Century Motet," Journal of the American Musicological Society, 34 (1981): 43-59.

${ }^{15}$ Stanley Sadie, ed. The New Grove Dictionary of Music and Musicians, p.511. 
It was in their conservative use of intervals, rhythmic flexibility, minimal chromaticism and lack of dissonant leaps that the Renaissance masters (Palestrina, Victoria et al) created a sense of solidity. Devices like these were necessary before more progressive means of creating interest (i.e. key relationships, modulation and development of thematic material) were realized by composers and later expanded by Hans Leo Hassler and Giovanni Gabrieli. Hassler and Gabrieli were masters of applying conservative doublechoir compositional techniques and implementing new and innovative ones. It was necessary for composers of double-choir compositions to define the function of the lowest voice of each choir in tutti sections, to have two 'bass' parts upon which a solid structure of sound could be built. Was the 'bass' part of one choir adequate in providing a foundation for both choirs in homophonic writing? Adrian Willaert's answer is twofold and is concerned with the distance between the two choirs. He states that dividing the choir can obscure the presence of the bass and that the more distance between the choirs, the more critical it was that the basses of the two choirs were essentially the same though sometimes an octave apart. As a result an eight part texture is reduced to seven (one part is doubled). This has been said to be the beginning of orchestration. 16

Music theorists Vicentino and Zarlino agreed that the bass of both choirs should sing in unison or at the octave. The exception which allows the use of a single bass line is when the choirs are located close to each other and the acoustics are such that one bass part can provide an adequate

16 Denis Arnold, Giovanni Gabrieli and the Music of the Venetian High Renaissance, (London: Oxford University Press, 1980), p. 80. 
foundation for all the other parts. For example, the double-choir compositions of Andrea Giovanni show that he was not as concerned about this theoretical rule. The organ galleries are not so far apart in St. Mark's and apparently the division of the bass part did not prove to be detrimental acoustically.

During the time of Hans Leo Hassler and Giovanni Gabrieli a simpler style of composition was being developed with less complex time signatures and musica ficta influencing tonality. Musical interest therefore was derived from experimentation with texture and ranges. A quest for castrati by churches in the 1570's and the use of women in the performance of secular works, such as madrigals, in the 1580's encouraged the expansion of ranges. Variation in texture was influenced by the selection of instruments doubling the choir parts (if at all) and by varying the number of singers on a part. In 1558 Zarlino states a preference for singing large scale works with one-to-apart. This is enforced by the responsoral performance of salmi spezzati at St. Mark's where "four singers in one choir and the rest (two or three to a part) in the other" were used. 17 Hassler did not use soloists or groups of soloists. 18

The use of the full choir was specified by the terms cappella or ripicno. Where solo voices by the composer were desired, solo or ooce was often indicated. This was not consistent, however, and the present day performer is left to determine which arrangement may work best for a particular occasion. This si placet ("as you please") idea was the composer's intent.

17Anthony Carver. Cori Spezzati. Volume I: The Development of Sacred Polychoral Music to the Time of Schür, p.11.

18 M. E. Jarvis, "The Latin Motets of Hans Leo Hassler." (Ph.D dissertation, University of Rochester, 1959), p. 271. 
$A$ ooce mutata is a cori spezzati compositional technique which was defined by Vicentino and Zarlino as "a substitution of a lower voice for soprano." Therefore, if the voicing for Choir I was SATB, the soprano would be transposed down an octave and sung by the first tenor of Choir II creating an ATTB arrangement. Vicentino further clarifies his intended voicing by using the term $a$ ooce piena ${ }^{19}$ which denotes a standard SATB arrangement. The difference in texture created by this compositional technique led the two choirs to be referred to as coro superiore (with the uppermost voice written in the treble clef) and coro grave (with the upper bass line in the bass clef).

\section{Performance}

The assignment of instruments to double the vocal parts (or replace them, depending on the performer's needs and preferences) was influenced by the designation of the coro superiore and the coro grave. Cornetts and violins were most frequently associated with the coro superiore which emphasized a bright, dynamic quality. Trombone, strings and bassoon were preferred to double the dark, strong tone of the coro grave, marking a distinct difference in color from the coro superiore.

Michael Praetorius (1571-1621) confirms the use of trombones or bassoons to double the coro grave and violins or cornetts, as well as flutes, for the coro superiore in his Svntagma Musica. He further stresses that a homogeneous sound is desirable and that "single instrument types" (whole consorts) should be used with each choir. For example, the coro superiore

${ }^{19}$ This is not to be confused with a piena voce which is singing suited to a large building as opposed to singing in chambers. Anthony Carver, Cori Spezzati, p.9. 
would be doubled by an ensemble of flutes and the coro grave by trombones. The writings of Praetorius have confirmed many aspects of what is known about double-choir compositions, however his writings describe German practices and do not necessarily reflect Italian traits.

"The clear indication [by omitting vocal and instrumental specifications, which were known to the composer] is that composers and editors were content to leave decisions about instruments and disposition of vocal resources in the hands of the 'maestro di cappella' or 'capo dei concerti'."20 The decision of vocal and instrumental 'orchestration' has to be made regardless of whether text is provided under each part or not. The absence of text does not indicate it was meant for instruments only and the presence of text does not eliminate the possibility for instrumental accompaniment. According to Denis Arnold, "to try to give a purely vocal performance is to court disaster." 21 It also seems likely that parts with awkward tessitura for the human voice were either doubled by instruments or simply played rather than sung. 22 This is particularly true for the bass line of the coro grave which frequently used low C's and required instrumental support.

20R. Charteris, "The Performance of Giovanni Gabrieli's Vocal Works: Indications in the Early Sources." Music \& Letters 71/3 (1990): p. 337.

21 Denis Arnold, Giovanni Gabrieli, (London: Oxford University Press, 1974), pp. 37-38.

22Denis Arnold, Giovanni Gabrieli and the Music of the Venetian High Renaissance, p. 170.

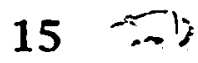




\section{Chapter 4 \\ Giovanni Gabrieli}

$\underline{\text { Life }}$

Giovanni Gabrieli, born in Italy about 1557, was the nephew of Andrea Gabrieli. In 1575 Giovanni traveled to Bavaria with his good friend, Hans Leo Hassler where he worked as an organist. Sources suggest two possible dates for Giovanni's return from Munich to Venice as being either 1579 or 1583.23 Giovanni's return may have been influenced by the death of his patron, Duke Albrecht, in 1579. He was replaced by Duke Wilhelm who affected both Lasso and Giovanni negatively:

Wilhelm supported the counter-reformation and introduced Jesuit Priests into Bavaria to combat the infiltration of Protestants. He replaced intermezzi of the court with religious dramas acted by boys of the chapel. 24

A second indication as to the approximate time of his return is the publication of De floridi oirtuosi d'Italia il primo libro de madrigali a cinque ooci in 1583. This anthology contains two of Giovanni's pieces which show Italian characteristics implying a return to Venice.

Andrea Gabrieli succeeded Merulo upon his resignation from the first organist position at St. Mark's in January 1585, creating a vacancy in the position of second organist. Giovanni Gabrieli was soon appointed second

${ }^{23}$ Sources supplying differring dates are: David Music, "Giovanni Gabrieli," p. 2, and Denis Arnold, Giovanni Gabrieli and the Music of the Venetian High Renaissance, p. 15.

24 Ibid., 15. 
organist where he remained until his death in 1612 At this time Zarlino was the maestro di cappella.

\section{Works and Influences}

Perhaps the single greatest influence on the development of Giovanni’s style was his uncle, Andrea Gabrieli. Andrea was familiar with the cori spezzati compositional techniques of Willaert, but it was not until he returned from a trip to Bavaria that he actually began composing in this medium.

From Lasso, Andrea learned a love for sonority but expanded his own personal style to include: groups of different ranges, greater distances between extreme parts, quick alterations of choirs, short well-defined phrases which build to tremendous climaxes, massive sounds, a predominance of homophony, simple textures and an emphasis on contrasts of dynamic and color. 25

Giovanni learned to master harmonic and textural simplicity from Andrea, and from Lasso he gained musical sophistication and the understanding that "the sheer magnificence of sound is enhanced when counterpoint is not neglected." 26 Andrea's later style provided an example of the importance of creating interest in cori spezzati by using various instruments so that each choir had its own distinct tone color.

There are many distinct features of Gabrielian compositions such as connecting a long note to a short one which heightens rhythmic vitality. Andrea liked dominant-tonic relationships created through the use of musica

25M. E. Jarvis, "The Latin Motets of Hans Leo Hassler," p. 268.

26Denis Arnold, Giovanni Gabrieli, p. 32. 
ficta and goes to major chords whenever possible. Giovanni was encouraged to do the same. 27 Both of the Gabrielis made use of the fall, harmonic sequences and dissonances from passing tones. Andrea demanded complex textures from Giovanni which included the use of cross-rhythms and a drawn out final cadence. He used different phrase lengths to create excitement while Giovanni worked with longer texts. Consequently Giovanni had to find other means of creating interest, which he did with great success even though there were no theoretical treatises of the time to assist him in realizing the potential of polychoral compositions. Later composers referred to the codification of cori spezzati devices by Michael Praetorius.

Giovanni's later works use regularly applied ornaments in the cantus firmus, and diminished and augmented intervals placed harmonically and melodically. However, the main divergence from Andrea's manner lies in Giovanni's gift of melody.

After approximately 1606 St. Mark's was in a state of decline. Singers were leaving for other regions which offered better pay for their services. It was noted that during this time they "did not have a single good contralto." 28 This period had a profound affect upon the music at St. Mark's and Giovanni Gabrieli. Cori spezzati was less common, the pompous splendor for which St. Mark's was known disappeared and the music of Giovanni displays modesty, introversion and melancholy. Furthermore, Bassano had retired and

27 It must be remembered that their music was distinctly modal.

28Denis Arnold, Giovanni Gabrieli and the Music of the Venetian High Renaissance, p. 259. 
Giovanni was "reluctant as ever to give the fruits of his labor to Gardano or Vincenti." 29

29Ibid., p. 261. 


\section{Chapter 5}

\section{Hans Leo Hassler}

$\underline{\text { Life }}$

Organist and composer Hans Leo Hassler (15641612) was born at Nuremberg, Germany as the second son of Isaak Hassler and died at Frankfurt. Hassler may have been a student of Leonhard Lechner, a pupil of Orlandus Lassus (c.1532-1594), and it is likely that Hassler was influenced by Lassus himself although it does not seem that he was one of Lassus' students. In 1584 Hassler left for Venice, becoming the first notable German composer to study in Italy. Hassler became a formal student of Andrea Gabrieli during his fifteen month stay and associated with other musicians such as Giovanni Gabrieli, Gioseffo Zarlino, Vincenzo Bell'haver and Baldassare Donato. He was also influenced during this time by Giovanni Gastoldi and Orazio Vecchi.30 In 1585 Hassler traveled from Venice to Augsburg, Germany where he became a private organist to the affluent Fugger family. There he supervised municipal music, played organ occasionally and performed for the Fuggers.

Octavian Fugger's death on August 1, 1601 prompted Hassler io return to Nuremberg as organist of the Frauenkirche as well as director of the town band which played for weddings, funerals and other social functions. 31 "In 1604 he was given a title of nobility ('von Roseneokh') by Emperor Rudolph

30 Simi, p. 76 , states that Hans Leo Hassler was a student of Giovanni Gabrieli. It is more likely that he was a student of Andrea Gabrieli, as other sources confirm (M. E. Jarvis, p. 3).

${ }^{31}$ M. E. Jarvis, "The Latin Motets of Hans Leo Hassler", p. 7. 
II."32 On February 19, 1605 Hassler married Cordula Clauss. They began a business together in $\mathrm{Ulm}$ in 1608 that did not last long. It was in 1608 that Hassler was appointed court organist to the Elector of Saxony in Dresden. From this point on he suffered from lung disease which eventually led to his death while visiting Frankfurt on June 8, 1612.

\section{Works and Influences}

Hassler's first compositions to be published were Laudate Dominum, á8 and Nuptiae factae, á12. They appeared in the Continuatio sacrarum cantionu.n published by Frederick Lindner in 1588. His first major work, Canzonette a Quatro Voci, was published in 1590. In 1591 Cantiones Sacrae de Festis Praccipuis totius anni, 4, 5, 6, 7, 8, \& plurium vocum, a collection of Latin motets for principle feasts of the year, was published. It contains twelve polychoral motets; nine for double-choir and three for triple-choir. The texts are from psalms, canticles, antiphons and other scriptural references from the Vulgate. This collection contains early works which demonstrate Italian influences (especially in form) and allude to the compositional innovations Hassler would later contribute to the development of polyphonic techniques. It is dedicated to his patron Octavian Fugger.

Two major works were published February 1,1596: Neüe Teütsche gesang (in the style of madrigals and canzonettes for $4,5,6,8$ voices) and Madrigali a 5, 6, 7, \& 8 ooci. They were dedicated to bishop Heinrich Julius and Landgraf Moritz von Hessen, respectively.

32Ibid., p. 8. 
Sacri Concentus contains motets for $4,5,6,7,8,9,10$ and 12 voices including twenty-two polychoral compositions, two of which are for triplechoir. It was originally published in 1601 by Augustus Vendelicor (containing fifty-two compositions), but was later reprinted by Paul Kaufmann in 1612 with ten motets and one ricercar added. This collection was dedicated to the Nuremberg Council and represents an ultimate fusion of the German and Italian styles.

In 1601 Hassler produced a collection of 39 German songs titled Lustgarten Neuer Teutscher Gesäng. Kirchengesäng: Psalmen und geistliche Lieder, a collection of 88 familiar melodies intended for congregational singing with melodies in the superius, was published in 1608 by Kaufmann. Hassler's last published collection, Litany Teutsch herrn Martini Lutheri, appeared posthumously in 1619.

Hassler was greatly influenced by those he met and studied with while in Italy. Since that time he had helped fuse the German and Italian styles.

In speaking of Hassler we cannot always compare his music to that of the "classical" sixteenth century, but must bear in mind that he was tremendously influenced by the Venetian school; that he was one of those connecting links between the late Renaissance and the Baroque. 33

"Of all the Italian influences that permeate the writings of Hans Leo Hassler, that of form is perhaps the most salient." 34 It is the form of the Italian Madrigal and Canzonette that are most frequently used by Hassler. Madrigals are through composed (alternating between homophony and

33 lbid., p. 14.

34Ibid., p. 221. 
polyphony) and declamatory in style. Canzonette are strophic two-part dance forms with a 'fa la la' refrain.

The cori spezzati compositions of Hassler and Gabrieli demonstrate a mixture of influences from a variety of sources. Although Hassler and Gabrieli began by composing music which represented the traits and styles of their particular geographic locations, later their styles merged. Hassler studied in Italy for fifteen months and both of the Gabrielis had visited Bavaria. The result of this fusion was a hybrid of compositional techniques which set new standards for the realization of cori spezzati compositions. The cori spezzati compositions of Hassler and Gabrieli anticipate the Baroque era and demonstrate their mastery and innovative application of cori spezzati compositional techniques. 


\section{Chapter 6}

\section{Angelus ad Pastores}

References to voice parts in this chapter will be made as they were during the time in which the scores presented here were composed, and as Hassler and Gabrieli have identified them. The four principal parts are the Cantus or Superiorus, Altus, Tenor and Bassus. Each additional voice part is referred to as Voice 5, Voice 6 and so on. These terms hold few restrictions as to which order they appear. For example, listed below are the voicings for Angelus ad Pastores as composeä by Hassler and Gabrieli.

\section{Angelus ad Pastores}

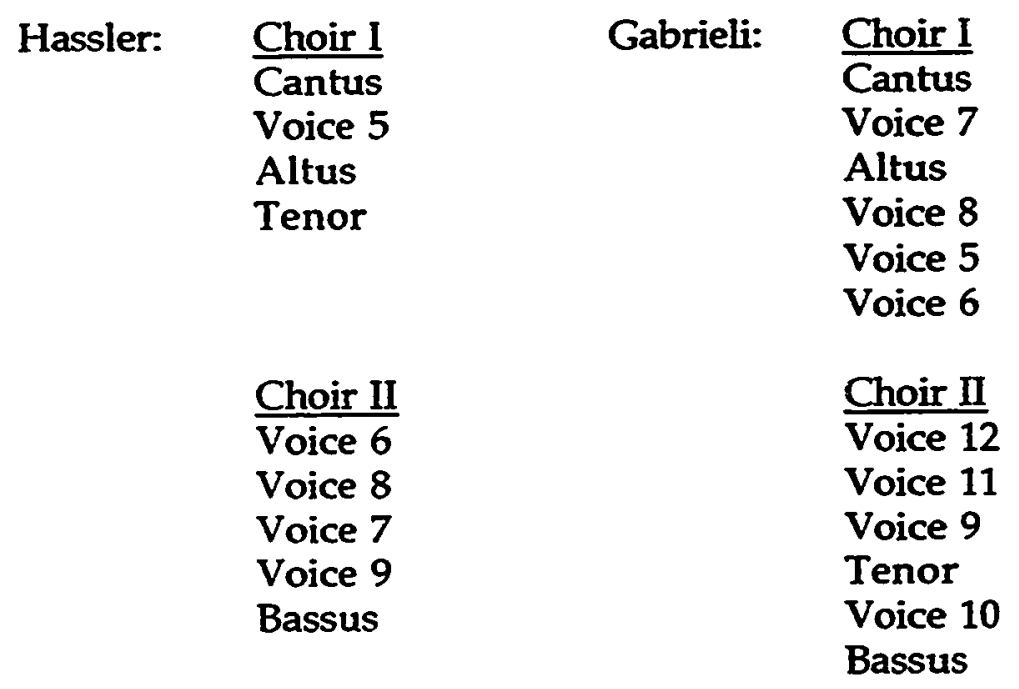

Giovanni Gabrieli's Angelus ad Pastores begins with the five voices of Choir I moving homophonically from A to a cadence on $E^{35}$. Choir I-

35During this time period major and minor tonalities were used as a matter of course though they were not theoretically defined as such. Anthony Carver in Cori Spezzati describes tonalities as major and minor while also using 
repeating the text "Angelus ad pastores ait" (The Angel said unto the Shepherds) with added embellishments-is joined by Choir II imitating Choir I's opening statement almost exactly but in the lower octave. The entrance of Choir l over the response of Choir II is not classical polyphonic style and creates a sense of urgency as the solo response of Choir II is omitted.

Choir I proceeds with "annuncio vobis" (Behold, I bring you) in measure 8 and Choir II responds with one note different: Voice 10 in Choir II begins the plirase in measure 9 on $\mathrm{E}$ instead of the $\mathrm{B}$ that Voice 8 of Choir I has in measure 8. This single change keeps the texture of Choir II in the lower octave from becoming too thick and thus the text remains clear. From measures 8-13 the pattern is more predictable: Choir I - Choir Il - tutti. This is then repeated with Choir II beginning the antiphonal exchange, forming a couplet. The text "annuncio vobis" uses short phrases, an accelerated harmonic pace and dotted rhythm to distinguish this text as being the actual words of the angels, sung with great pride and enthusiasm (Example 3).

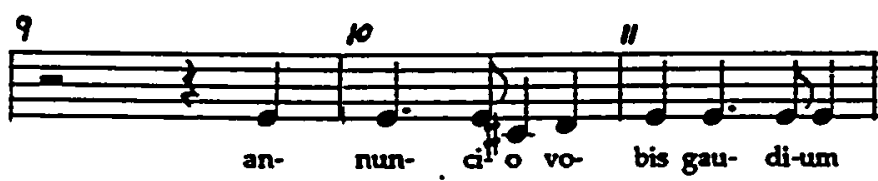

Ex. 3. Measures 9-11. Short Phrase and Dotted Rhythm.

Gabrieli ends the first section with Choir II singing the text "quia natus est vobis hodie Salvator mundi" (for unto you is born this day the world's

the term modulation. These terms are progressive for the time period, however they most accurately describe the music and will be used here. 
Redeemer). I lere the text is expressed in longer, majestic, authoritative, flowing phrases (Example 4).

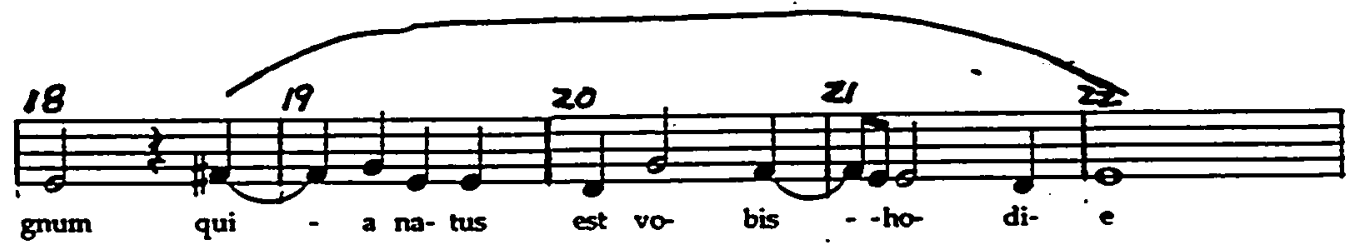

Ex. 4. Measures 18-22.

Lasting only six measures, the "alleluia" is set antiphonally in 3/4 time-symbolic of Trinitarian beliefs-with one tactus per each measure. The result is a quickened tempo, lighter texture and celebratory mood-in actuality, a response in itself to the preceding texts (Example 5).

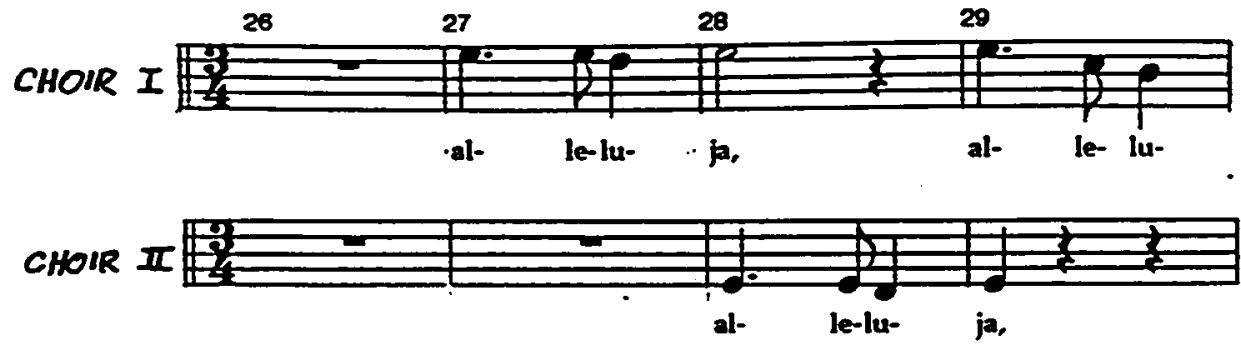

Ex. 5. Measures 26-29. Rhythm and Short Phrases of Both Choirs.

This gives way to the "Gloria" text in $3 / 2$ time. "Gloria" text is sung twice tutti. Here Gabrieli uses slower harmonic rhythm and the combination of all voices to emphasize the text "Gloria in excelsis Deo" (Glory to God in the Highest). From measures 39 - 44 imitation between Choir I and Choir II prevails to the text "et in terra pax hominibus voluntatis" (and on earth peace 
to men of good will). The inclusion of the Greater Doxology, or "Gloria" after the psalm text makes this composition functional within the format of the Roman Catholic liturgy. This motet was probably composed for

Christmastide as the Doxology of the Mass Ordinary is not part of Mass during Advent.

The final "alleluia" begins at measure 45 and ends at measure 55 and is sung alla breve in the following form: Choir II - Choir I - Choir II - Choir I tutti. It is then repeated from measure 56 until the final piagal cadence at measure 66, ending the composition in E Major.

Angelus ad Pastores first appeared in a collection containing five of Gabrieli's motets published in 1587. It is an early composition of Gabrieli and demonstrates partiality to the stile famigliare (i.e. mostly homorhythmic and syllabic). This composition shows "he had a fine sense for structural articulation, for rhythmic richness and for color contrasts." 36 The form is:

Metric: $\quad$ A

Thematic: A

mm:
B

[B $\quad$ C $\quad$ C $]$ [D [27-32 (33-35
A

E E]

39-44]

$55-66]$

*Phrase: $8+10+86+6+6+11+11$

("Phrase length is shown by the number of measures they contain.) The question is then, what holds this composition together? The metric structure is one answer. The use of $3 / 4$ meter and $3 / 2$ meter, beginning at

36Egon Kenton, Life and Works of Giovanni Gabrieli Musicaological Studies and Documents. Armen Carapetyan, editor. (American Institute of Musicology, 1967), p. 267. 
measures 26 and 33 respectively, provide metrical variety and assist in emphasizing changes in text. However, Angelus ad Pastores begins and ends with 26 measures of alla breve, therefore the metric form is ABA. The number of measures contained in each phrase also plays a part in the overall unification. Section A (measures 1-26 in cut time) consists of three large phrases having $8(4+4), 10(5+5)$ and 8 measures, an ABA form in itself. Section B is composed of three sets of 6 measures, the second of which is constructed of two phrases of three measures: $6+(3+3)+6$. Angelus ad Pastores ends with an eleven measure "alleluia" which is repeated $(11+11)$.

Angelus ad Pastores by Hans Leo Hassler begins with twelve measures of tonal imitation in the four voices of Choir I. Like Gabrieli, Hassler was extremely adept in the art of contrapuntal composition. The difference lies in that "he quite often begins with an imitative paragraph of considerable breadth" 37 whereas Gabrieli tends to reserve his use of polyphony for tuttis. The six measure opening statement appears in Voice 5 and is immediately imitated by the Altus (Example 6).

${ }^{37}$ Anthony Carver, Cori Spezzati. Volume 1: The Development of Sacred Polychoral Music to the Time of Schuitz, p. 208. 


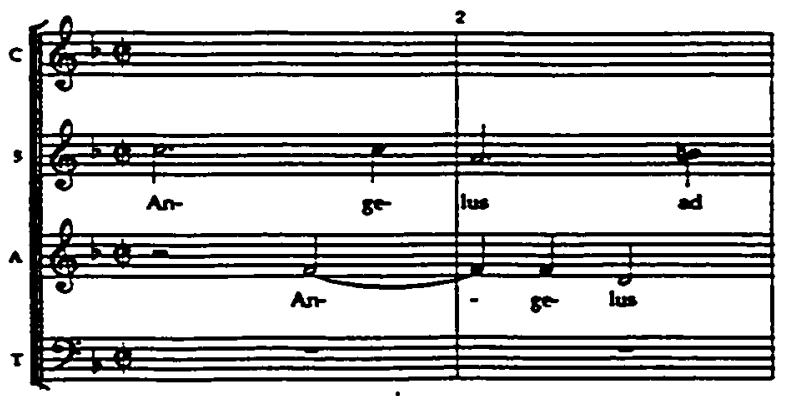

Ex. 6. Measures 1-2. Imitative Entrance.

The text "ad pastores ait" from measures 3-5 is repeated in measure six in preparation for a second and more final cadence-hereafter referred to as a Repeated Cadence. At the same time the Cantus enters as the last voice to take part in the imitation giving the affect of resolution and growth.

A similar scenario of a cadence overlapping with entering voices occurs at measure 12 (Example 7).

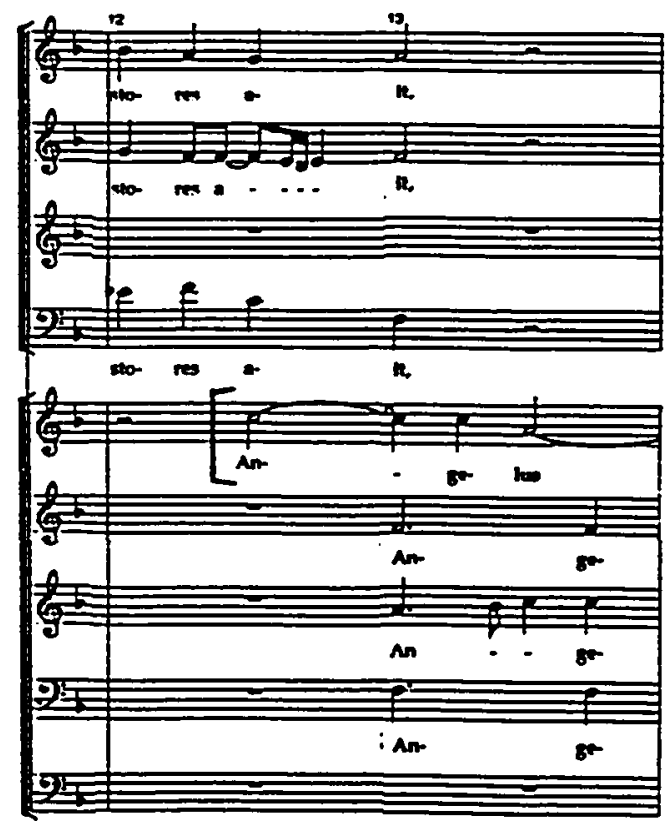

Ex. 7. Measures 12-13. Choir Il Enters and Choir I Cadences. 
I lere all four voices of Choir I cadence simultaneously while the voices of Choir II begin. The entrance of four of the five voices in Choir II at this cadence further expands the power, depth and texture of the opening section which began with one voice. Choir II completes a Repeated Cadence in measure 18 and then anticipales the entrance of Choir I which enters for the final repetition and cadence of the words "Angelus ad pastores ait" (The Angel said unto the Shepherds) (Example 8).

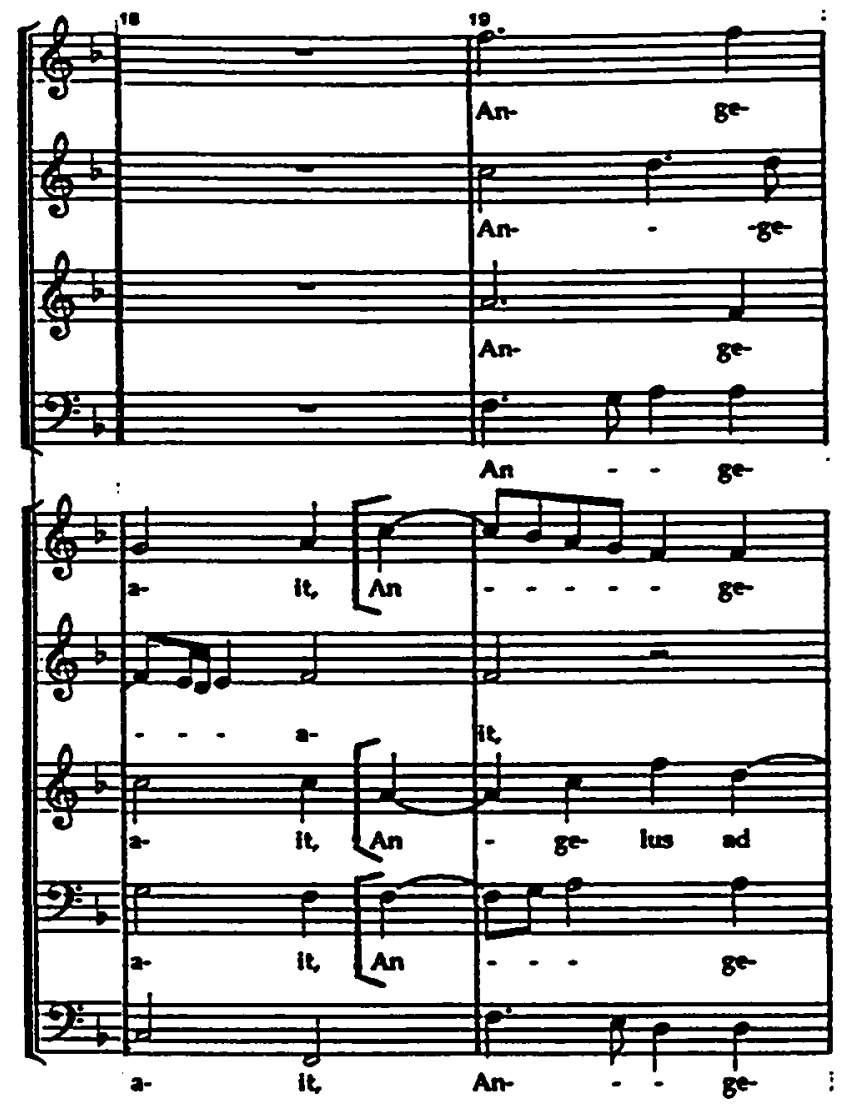

Ex. 8. Measures 18-19. Anticipation by Choir II. 
The cadence of Choir II and entrance of Choir I in measure 18 overlaps as well. In fact, Voice 8 of Choir II does not cadence until after Choir I has entered. The first section closes with both choirs cadencing together in measure 22.

The second section begins with the two choirs singing "Annuntio vobis" (Behold, I bring you) three times antiphonally and then singing "gaudium magnum" (great joy) together. The first statement by Choir I and response by Choir II of "Annuntio vobis" is repeated (with the third statement omitted) and a final, more embellished declaration of "gaudium magnum" is made by both choirs. Choir I continues with the text "quia natus est vobis hodie Salvator mundi" (for unto you is born this day the world's Redeemer) beginning on an F Major triad and ending on C Major. Choir II then responds with the same text beginning on $C$ Major and ending on $F$ Major.

The second section, described above, then repeats with three differences. First, what originally consisted of three statements of "Annuntio vobis" is reduced to one which is then followed-as before--by both choirs singing "gaudium magnum" together. Second, the rhythms in both choirs for the words "quia natus est vobis hodie Salvator munaii" are more active. Finally, a codetta beginning in measure 57 closes this section. The text "Salvator mundi" is sung twice antiphonally and then twice with both choirs together in a Repeated Cadence.

Measure 64 marks the third and final section-an "Alleluia" refrain which begins in $3 / 2$ time. Both choirs participate in singing four antiphonal responses to the text "alleluia." The time signature then changes back to alla 
breve in measure 74 and the choirs sing "alleluia" twice in a cadence. However, this is not a Repeated Cadence as the notes and harmony do not repeat though the text is the same. The indication is therefore that the composition is not complete; the entire final section repeats. Three measures are added to make the closing a Repeated Cadence.

The form of Angelus ad Pastores by Hassler is much more obvious than Gabrieli's composition on the same text. This is true in most cases as Hassler preferred clearly defined sections. The overall form is outlined below.

Thematic: A $\quad$ B $\quad$ B1 $\quad$ (codetta) D $\quad$ D

mm. $\quad 1-22 \quad 23-42 \quad 43-56 \quad(57-63) \quad 64-78 \quad 79-96$

\section{Summary}

Angelus ad Pastores displays Hassler's ability to formulate strong sequences of musical events, which hold his compositions together. His style in this sense is very Germanic. His repeated sections are of a larger scale than the intricate nuances of Gabrieli's Italian style. For example, in Angelus ad Pastores, Hassler repeats the B Section (measures 23-42) while Gabrieli repeats a C Section spanning three measures (measures 33-36).

A notable similarity in structure is the manner in which both composers set the text. "Angelus ad pastores ait" is first sung by Choir I and finally tutti. Although Hassler also has Choir II sing this text, this does not impair the comparison. The next phrase of text, "Annuncio vobis gaudium magnum", is set antiphonally by both composers. "Quia natus est vobis hodie Salvator mundi" is only sung by one choir; in Hassler's case, one choir 
at a time. Finally, "alleluia" is sung-in both cases-first antiphonally and then tutti. In Gabrielis case the first "alleluia" (measures 26-33) is in 3/4 time while the second "alleluia" (measures 45-66 located after "Gloria") is alla breve. Hassler has also set the first "alleluia" in a triplet meter ( $3 / 2$ time) followed by a second "alleluia" alla breve. This study did not determine whether the metrical changes from triple to alla breve for the "alleluia" found in the works of both composers were: 1) coincidence, 2) have some significance beyond structural integrity, or 3 ) are the result of being instructed by a mentor as to compositional conventions. It is, however, known that the use of triple meters is symbolic of Trinitarian beliefs. 


\section{Chapter 7}

\section{Beati Omnes}

The voicing by Hans Leo Hassler and Giovanni Gabrieli for Beati Omnes is:

\begin{tabular}{|c|c|c|c|}
\hline Hassler: & $\begin{array}{l}\text { Choir I } \\
\text { Cantus } \\
\text { Voice } 5 \\
\text { Voice } 7 \\
\text { Voice } 8\end{array}$ & Gabrieli: & $\begin{array}{l}\text { Choir I } \\
\text { Cantus } \\
\text { Altus } \\
\text { Voice } 5 \\
\text { Tenor }\end{array}$ \\
\hline & $\begin{array}{l}\text { Choir II } \\
\text { Altus } \\
\text { Tenor } \\
\text { Voice } 6 \\
\text { Bassus }\end{array}$ & & $\begin{array}{l}\text { Choir II } \\
\text { Voice } 7 \\
\text { Voice } 6 \\
\text { Voice } 8 \\
\text { Bassus }\end{array}$ \\
\hline
\end{tabular}

Beati Omnes by Giovanni Gabrieli begins with Voice 8 of Choir II which is offset from the homophonic entrance of Voice 7, Voice 6 and Bassus. The extended phrases consist of long note values (Example 9).

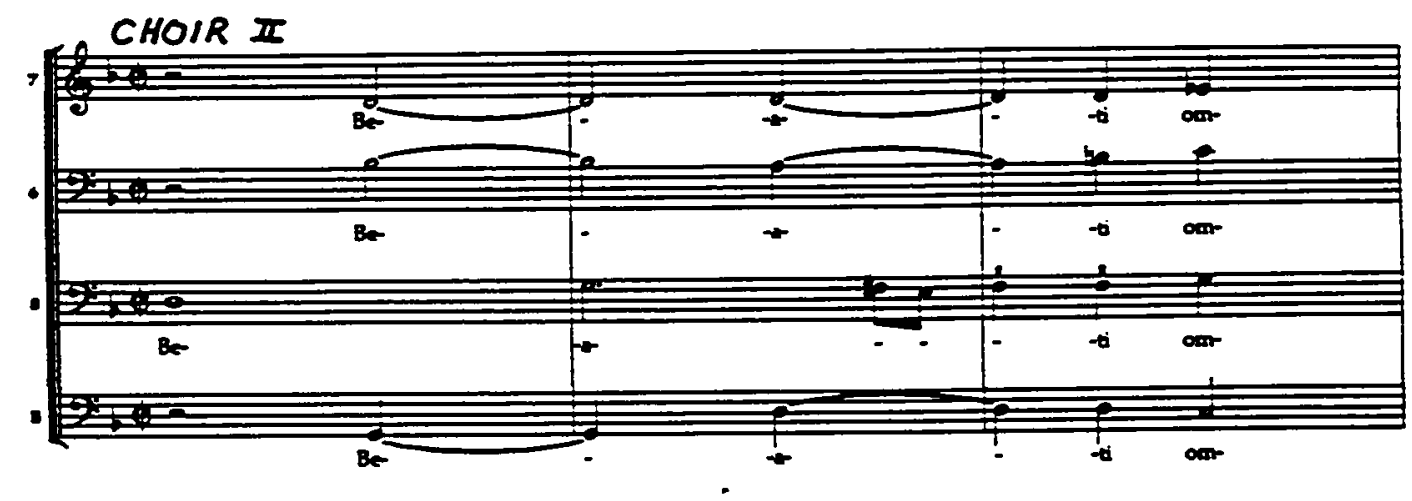

Ex. 9. Measures 1-3. Extended Phrasing and Long Note Values. 
After the first cadence in measure 4, Voice 8 immediately continues to the text "qui timent Dominum" (who fears the Lord) with Voice 6, Bassus and Voice 7 quickly imitating in that order. To the text "qui ambulant in viis ejus" (who walk in his ways) in measure 8 Choir I takes over using note nere, i.e. singing shorter note values and notated ornamentation normally expected with the higher tessitura of Choir I (Example 10). This is different from the longer note values of the previous measures and consistant with the shorter note values which appear in the following phrases.

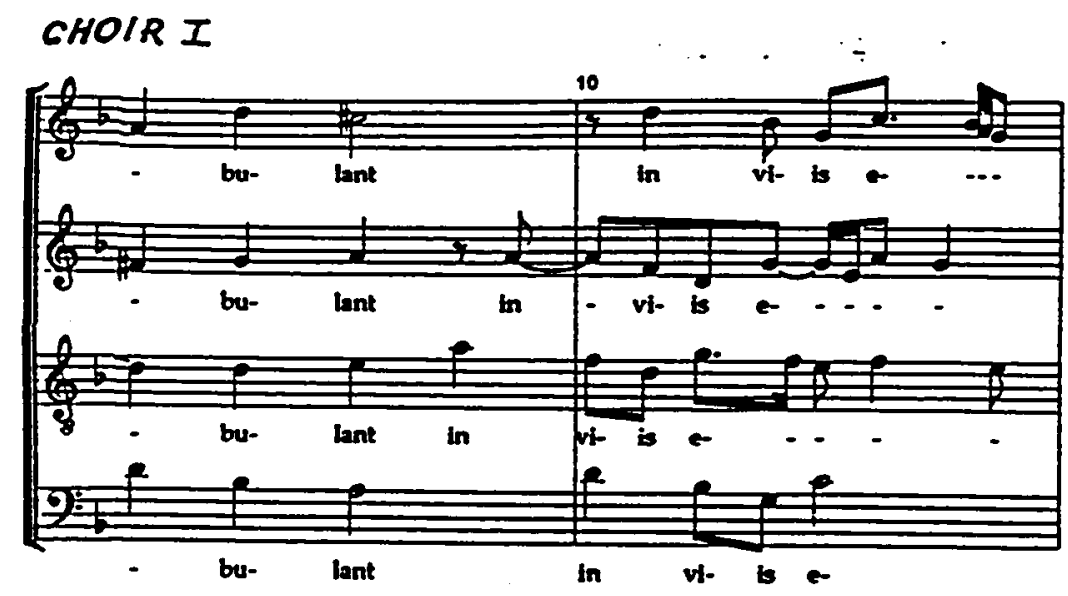

Ex. 10. Measure 10. Use of Shorter Note Values.

Choir I is then joined by Choir II in singing the text "labores manuum tuarum" (You shall eat the fruit of the labor of...) homophonically. The absence of a Repeated Cadence here prior to the change in mood, style and pace of the following section is intentional and corresponds to the line of psalm text not yet being completed. 
In measure 14 Gabrieli begins an antiphonal section with Choir I singing text which belongs to the previous section: "quia manducabis" (your hands) (Example 11).

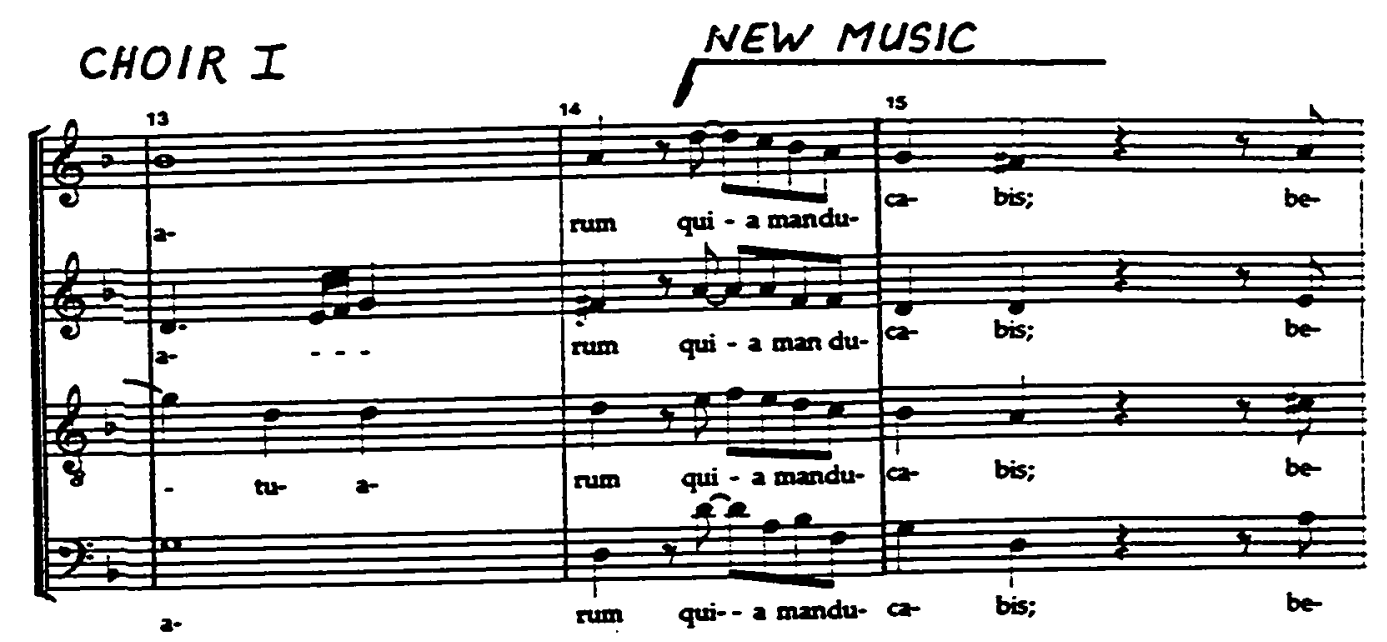

Ex. 11. Measures 13-15. Psalm 128:2 Interupted at Measure 14 with New Theme, Texture and Rhythm.

The text "Beatus es, et bene tibi erit" (You shall be happy, and it shall be well with you) follows, however the antiphonal section does not close with tutti choirs as one would anticipate. Instead, measure 19 contains an antiphonal repetition of measure 16 on the text "beatus es" in a different key. The tutti is then sung to the text "beatus es" in measure 20 immediately followed by Choir I completing this line of text with "et bene tibi erit."

The section just discussed began with a six note phrase in which the text belonged to the previous section while the notation-an antiphonal statement--belonged to the music which followed (see Example 11). In neasure 22 Gabrieli used a similar device to unify the preceding measures with the new text which follows. In measure 22 "Uxor tua" (Your wife) is sei 
homophonically with Choir I and Choir II singing together, a texture one anticipates hearing complete the previous antiphonal exchange. However, this homophonic cadence contains new text and overlaps with the entrance of the following phrase made of shorter note values (Example 12).

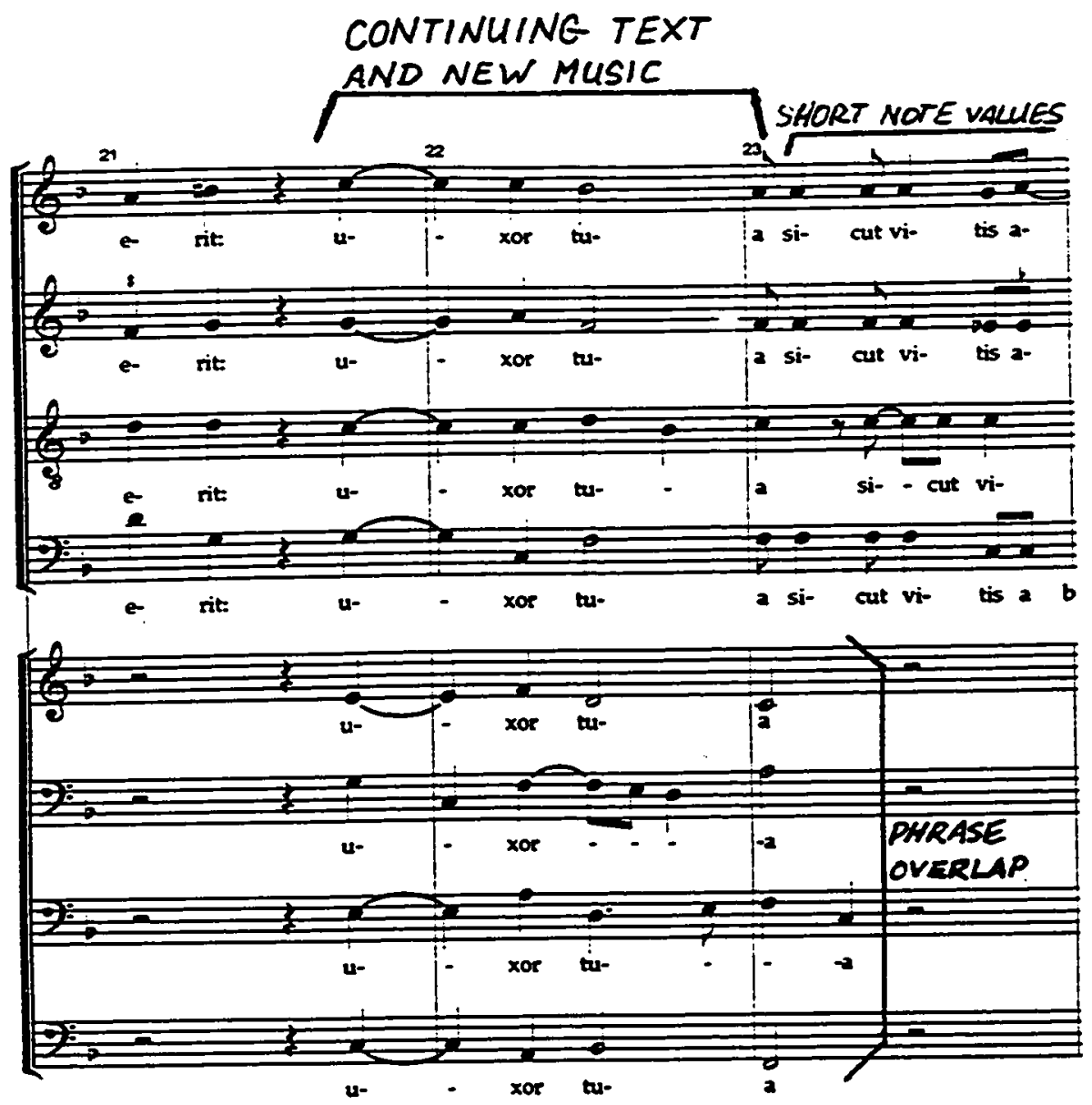

Ex. 12. Measures 21-23. Continuing Text and New Music.

In measures 23 - 28 the text "sicut vitis abundans, in lateribus domus tuae." (...will be like a fruitful vine, within your house) is set in the following, 
standard antiphonal form: Choir I + Choir II + Tutti. From measures 19 - 29 one can easily recognize the harmonic movement around the circle of fifths, a Gabrielian trait established by Andrea and continued by Giovanni.

The tutti section which ends in measure 28 and the stretto beginning in measure 30 is divided by a single statement of the text "filii tui" (Your sons) by Choir II. The ensuing text "sicut novellae olivarum, in circuitu mensae tuae" (...will be like olive shoots around your table) involves all eight voices entering in stretto, gathering momentum until the cadence in measure 35. Measures 35 to $\mathbf{4 8}$ are homophonic with changes in texture resulting from alternations between Choir I, Choir II and tutti.

In 3/4 time with one tactus to each measure, the text "Et videas filios filiorum tuorum" (And may you see your children's children) spans from measures $49-69$. The choirs alternate antiphonally in statement and response sequences, however tutti sections are not present. This section is described in the following graph:

\begin{tabular}{llllllllll} 
Key: & G & & & & & & & & \\
m. & I49 & 150 & I51 & I52-54 & II55 & I56 & $157-59$ & I160 & 161 \\
\hline I & IA & I & IC & I & IIA & I & ID & 11 & IA \\
II & I & IB & I & ID & II & IB & I & IIA & I
\end{tabular}

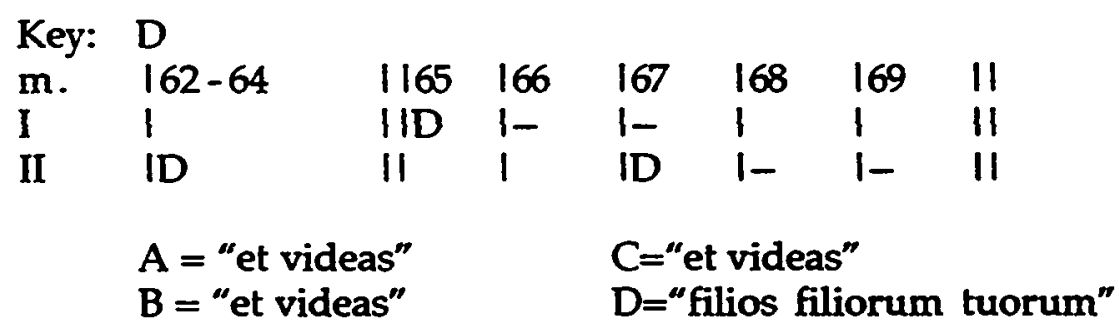


As demonstrated in the above graph, the first full exposition of the material used in this section spans from measures 49 - 54 and contains all four musical statements (A, B, C and D). The next repetition of the materialmeasures 55 - 59-is missing statement $C$; the statement spanning measures 60 - 64 is missing statement B and C; and finally from measures 65 - 69 statements A, B and C have been omitted.

Statement D appears five times. The use of Stimintausch (voice exchange) in statement $\mathrm{D}$ delineates this section and further clarifies the form. Beginning in measure 52 Statement $D$ is first sung by Choir II with the voicing in the following order from top to bottom: 1, 2, 3, 4 (Tenor, Voice 6 , Voice 8 and Bassus). Choir $I$ has the next entrance of statement $D$ in measure 57 with the voicing in a different order: $3,1,2,4$. This same order is kept when statement $D$ is sung by Choir II in measure 62 . The last two uses of statement $D$ overlap to suggest a completion of the section, however the lack of a tutti emphasizes the meaning of the text. The voicing for Choir $I$ and Choir II in measures 65 and 67 respectively are, once again 1, 2, 3, 4. The overall form of this $3 / 4$ section-which spans measures 49 - 69-can therefore be described as ABBA: Other uses of voice exchange can also be identified in statements A, B and C which use the text "et videas" (and may you see).

Measure 70 returns to alla breje. The text "pacem super Israel" (Peace be upon Israel) is sung tutti for a homophonic closing which employs the use of descending lines and ornamentation.

In the same way that Giovanni Gabrieli uses six measure increments in Angelus ad Pastores, seven measure phrases are used to organize the through composed structure of Beati Omnes. 


$\begin{array}{llllll}\text { Section: } & \text { A } & \text { B } & \text { C } & \text { D } & \text { E } \\ \text { Measure: } & 1-14 & 15-35 & 36-49 & 50-70 & 71-74\end{array}$

Choir I begins Hans Leo Hassler's Beati Omnes with 11 measures of imitation in $\mathrm{G}$ minor and a cadence in D Major. Voice 5 starts the imitation on $\mathrm{D}$ and is imitated by Voice 7 at the fourth. In measure 4 Voice 8 enters on $\mathrm{D}$ and is followed by Cantus imitating at the fourth in measure 6. Choir I resumes in D Major at measure 12 with the text "Qui ambulant in viis ejus" (Who walk in his ways) and cadences in measure 17 in G Major. This segment is homophonic and uses rhythmic imitation. In measure 12 Voice 7 enters prior to Cantus, Voice 5 and Voice 8 which then homophorically imitate the rhythm established by Voice 7. This rhythmic imitation is found only at the entrance in measure 12 and does not continue. A similar situation occurs agair. in measure 15 with the repetition of the text "in viis ejus." In this case, however, the premature entrance of Voice 5 is merely in anticipation of the repeated text. None of the other voices imitate the melodic or rhythmic pattern of Voice 5's entrance. From measures 15 - 17 the note values are longer and ornamentation is limited, therefore emphasizing the text and anticipating a firm cadence. This loosely fits the description of a Repeated Cadence.

Choir II enters for the first time in measure 17, overlapping the cadence by Choir I. The text "Labores manuum tuarum quia manducabis" (You shall eat the fruit of the labor of your hands) is set homophonically and the harmonic progression follows the circle of fifths until the cadence on $G$ Major in measure 22: D, G, C, F, C, G, (C), D, G, C, F, C, (D), G. The next line of text- 
"Beatus es, et bene tibi erit" (You shall be happy, and it shall be well with you)-is sung by Choir II as well, but highly contrasts the style of writing just heard in measures $17-22$. Measure 22 begins in stretto and uses note nere. This phrase is highly ornamented with a quick harmonic pace. Choir I returns in measure 26 with the text "uxor tua sicut vitis abundans in lateribus domus tuae" (Your wife will be like a fruitful vine within your house) set homophonically.

Choir II sings the next line of text from measures 30 - 38: "Filii tui, sicut novellae olivarum, in circuitu mensae tuae" (Your sons will be like olive shoots around your table). The first phrase is set homophonically with limited ornamentation. The second phrase, "in circuitu mensae tuae," employs more ornamentation (suspensions, shorter note values and turns) and is first sung by the bottom three voices of Choir II: Tenor, Voice 6 and Bassus. It is repeated by the top three voices of Choir II using the same rhythmic pattern although the harmonic changes are different. All four voices close the phrase with a final statement of "mensae tuae." The change in voicing breaks the pattern of the preceding four part singing and is an example of text painting. The rotating of vocal lines, and the use of turns and mordents musically describes the text "in circuitu mensae tuae" (around your table) (Example 13). 

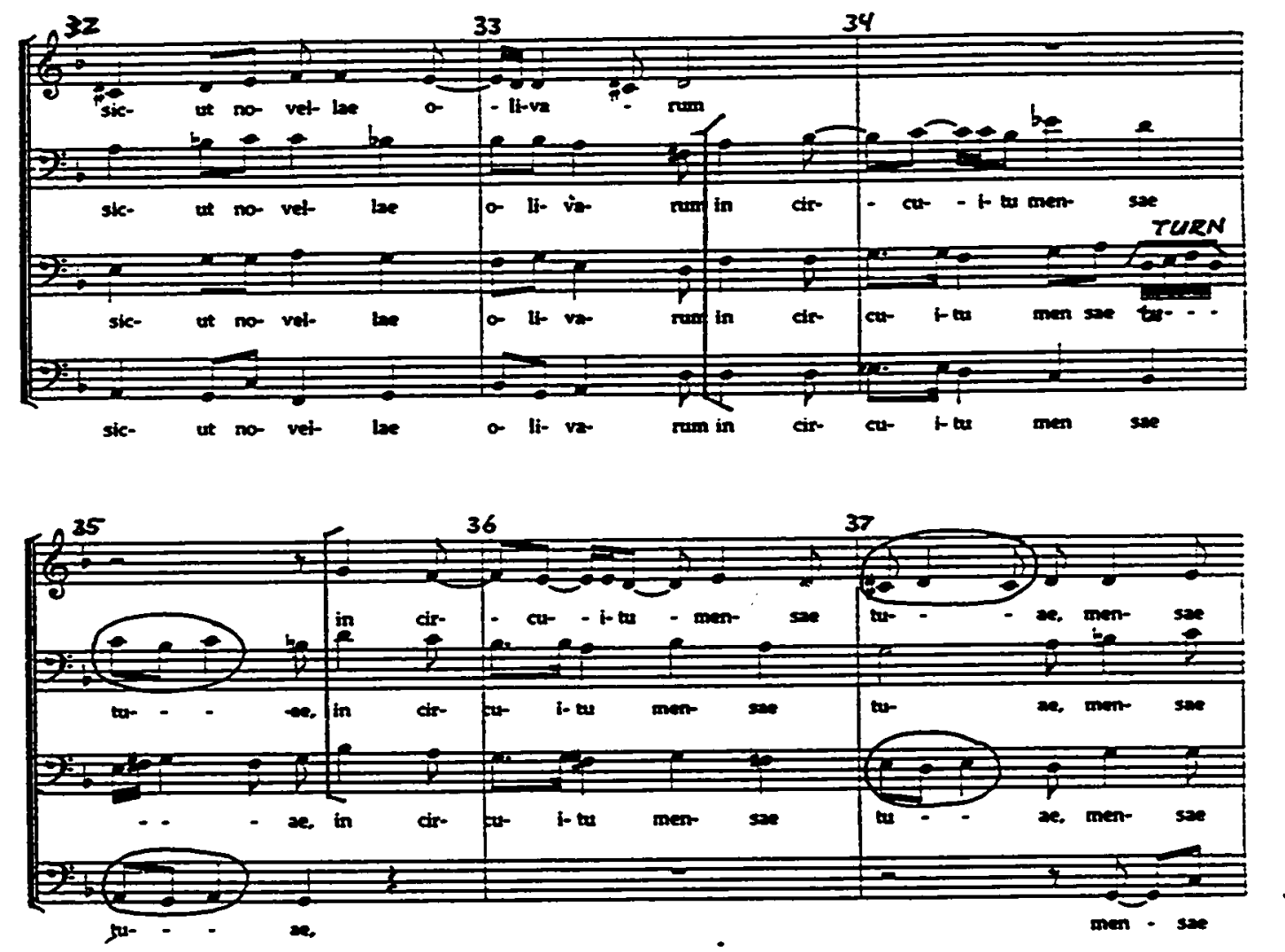

Ex. 13. Measures 32-37. Text Painting. Mordents Are Used On The Word "Tuae" (Circled in Example).

Choir I and II sing tutti for the first time in measure 39. Although they start together, the final cadence of the phrase is off-set: Choir I cadences in measure 43 on A Major and Choir II finishes the text in measure 44 on D. In measure 44 the choirs resume "off-set" with Choir I beginning and Choir II echoing. The two phrases spanning measures $44-48$ do not show melodic, harmonic or rhythmic imitation between the two choirs. Choir II merely echoes Choir I using similar rhythms. At measure 49 the progression 
to imitation is completed. What started out as a tutti in measure 49 was altered into an echo in measures $44-48$ and culminates in an imitative section beginning with measure 48 . The two phrases "benedicat tibi" and "benedicat tibi Dominus ex Sion" (The Lord bless you from Zion) are stated by Choir I with Choir II responding in imitation after each (Example 14).
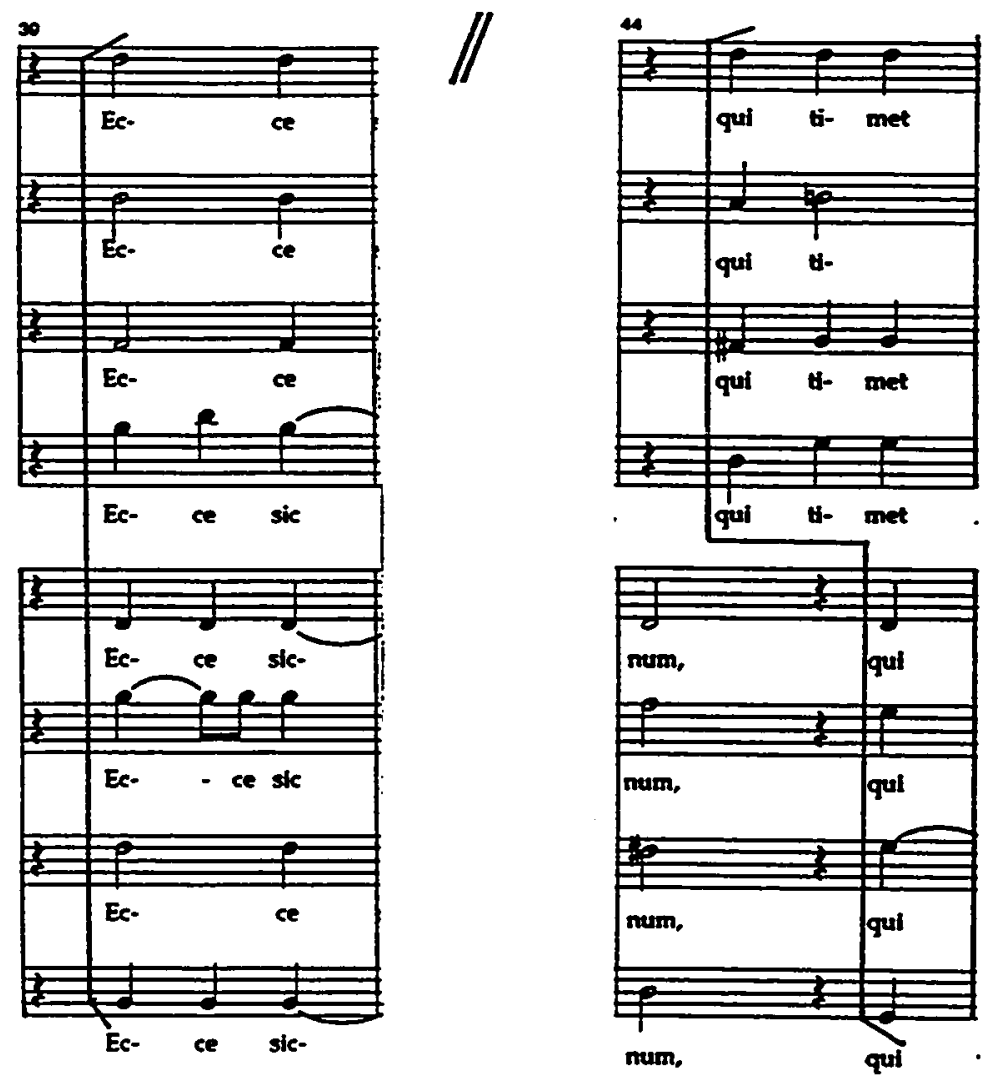

Ex. 14. Measures 39, 44, 46, 48-50. Progression Toward Antiphonal Singing. 


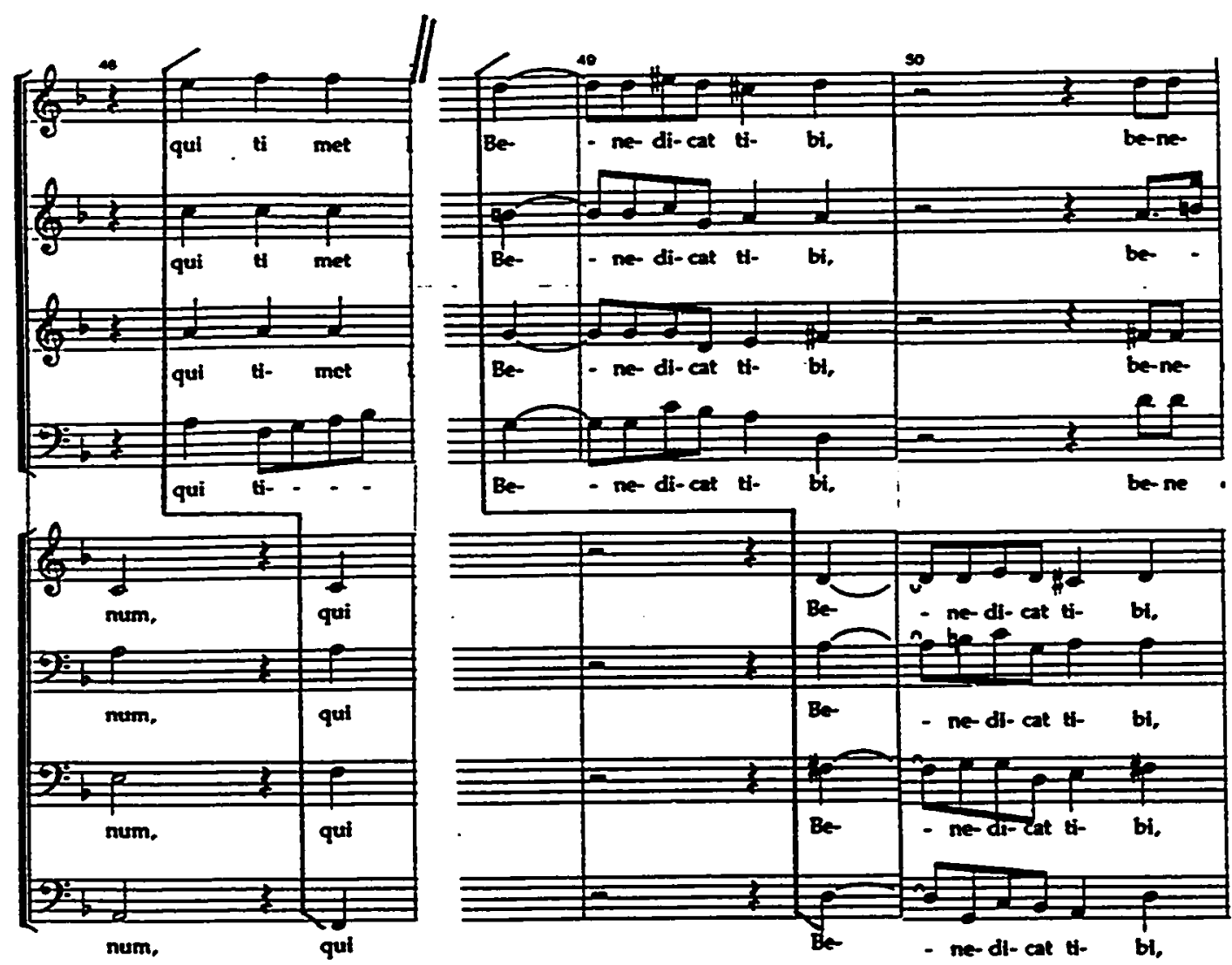

lix. 14. Measures 39, 44, 46, 48-50. Progression Toward Antiphonal Singing.

I lassler sets the next two lines of text-"Et videas bona Jerusalem omnibus diebus vitae tuae" (And may you see the prosperity of Jerusalem all the days of your life) and "Et videas filios filiorum tuorum" (And may you see your children's children)-in 3/2 time. Giving each measure one tactus will ensure the correct tempo. The first of these two phrases is set homophonically for Choir I. The second phrase-tutti and homophoricbegins in measure 64 . In measure 70 the meter returns to alla breoe for "I'acem super lsrael" (Peace be upon Israel). Here the choirs are singing tutti 
and the upper three voices of Choir II sing ornamentation using shorter note values.

The form used by Hassler is $A B$ (codetta)CC. Section A-measures 1 to 39-is organized in 6 or 12 measure phrases and has the form ABA in itself: mm1-18, mm18-22 and 23-38. Measures 18-22 divide Section $A$ in half and are easily identified by the harmonic content which moves smoothly around the circle of fifths. Section A ends with Choir II repeating the text "in circuitu mensae tuae" (around your table) and alludes to a Repeated Cadence on the text "mensae tuae". Section B begins in $\mathrm{Bb}$, travels through the circle of fifths, lands in $\mathrm{G}$ at measure 45 , cadences at measure 55 and is concluded with a codetta in 3/2 (measures 55-65). The six measures of the B Section which incorporates tonalities within the circle of fifths, serves a second formal function as it divides the entire work in half. $C$ is the final section, spanning from measures 65-77 and then repeating without variation.

\section{Summary}

Gabrieli incorporates the use of antiphonal singing, however the note values throughout his composition are very short. Gabrieli completes the text and closes the composition with measure 74. With measure 77 Hassler completed the text, however he chose to repeat measures $65-77$. Therefore Hassler completes Beati Omnes with 90 measures. 


\section{Chapter 8}

Iubilate Deo

The next two compositions begin with the text Jubilate Deo, however the texts have been taken from two separate psalms. Giovanni Gabrieli uses the text of Psalm 100: 1-5 while Hans Leo Hassler uses Psalm 66: 1-4. The voicing for Jubilate Deo is:

\begin{tabular}{|c|c|c|c|}
\hline Hassler: & $\begin{array}{l}\text { Choir I } \\
\text { Cantus } \\
\text { Voice } 5 \\
\text { Voice } 6 \\
\text { Voice } 8\end{array}$ & Gabrieli: & $\begin{array}{l}\text { Choir I } \\
\text { Cantus } \\
\text { Altus } \\
\text { Voice } 5 \\
\text { Tenor }\end{array}$ \\
\hline & $\begin{array}{l}\text { Choir II } \\
\text { Altus } \\
\text { Voice } 7 \\
\text { Tenor } \\
\text { Bassus }\end{array}$ & & $\begin{array}{l}\text { Choir II } \\
\text { Voice } 7 \\
\text { Voice } 8 \\
\text { Voice } 6 \\
\text { Bassus }\end{array}$ \\
\hline
\end{tabular}

Jubilate Deo (Sing Joyfully to God) by Giovanni Gabrieli begins with Voice 5 stating the rhythmic and melodic pattern which is imitated by the Altus, Cantus and Tenor at the fifth. The imitation continues to the text "omnis terra" (all the earth). Stressing the word "omnis" (all), each voice enters in most cases with a leap of an octave and no less than a fourth. The "fall"-a five note descending pattern and favorite Gabrielian techniqueenhances the text in this imitative sequence as the notes gravitate toward "terra" (earth). The cadence in measure 8-an open fifth on G-completes the opening imitative sequence. (Example 15). 


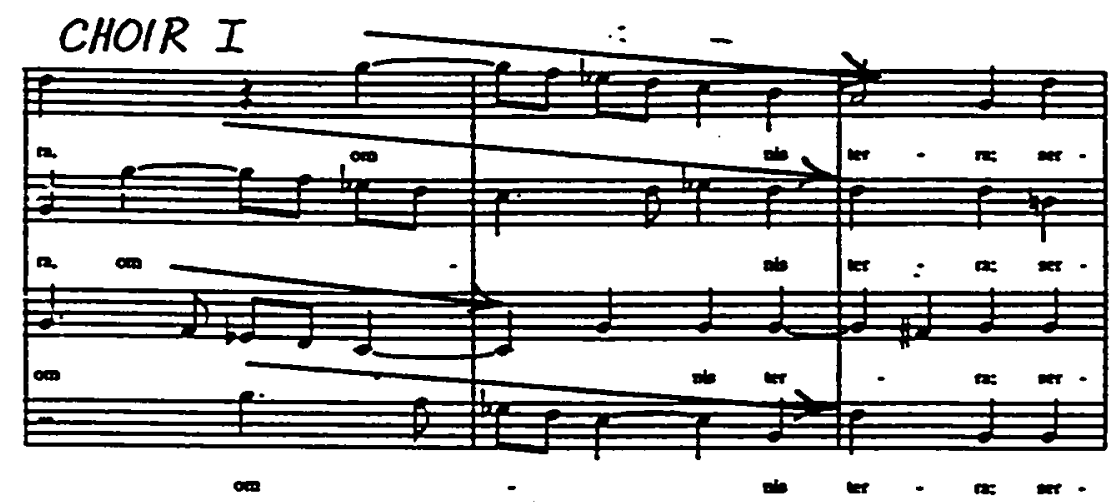

Ex. 15. Measures 6-8. Text Painting.

The text which follows (measures 8-11 and 11-13) is set

homorhythmically, the harmonic pace is very quick and forms a Repeated Cadence. Interest is created by ornamentation in the Tenor line and by Voice Exchange between the Cantus and Altus in the repetition (measures 11-13). Choir II enters for the first time in measure 13 and is joined quickly by Choir I to finish the text to verse two of the psalm.

Measures 18-23 marks the beginning of verse three and is antiphonal: Choir II + Choir I + Tutti. Voice Exchange is used here between the statement of Choir II and the response by Choir I. Measure 23 changes texture dramatically as Choir Il proclaims "quoniam" (because) homorhythmically to emplasize the importance of the text which follows. "Dominus ipse est Deus" is then sung by Choir II using rhythmic and melodic imitation at the fourth, inversion and longer tones for stressing "Deus" (God). The Choirs proceed antiphonally-Choir I + Choir II + Tutti. "Et non ipsi nos" (and we are his) in measures 30-32 demonstrates the complexities (and perhaps arrogances) of mankind using imitation, delayed entrances, creative voice 
pairing, syncopation and ornamentation. The text and meaning of this passage is therefore appropriately displayed, "man did nut make God" (Example 16).

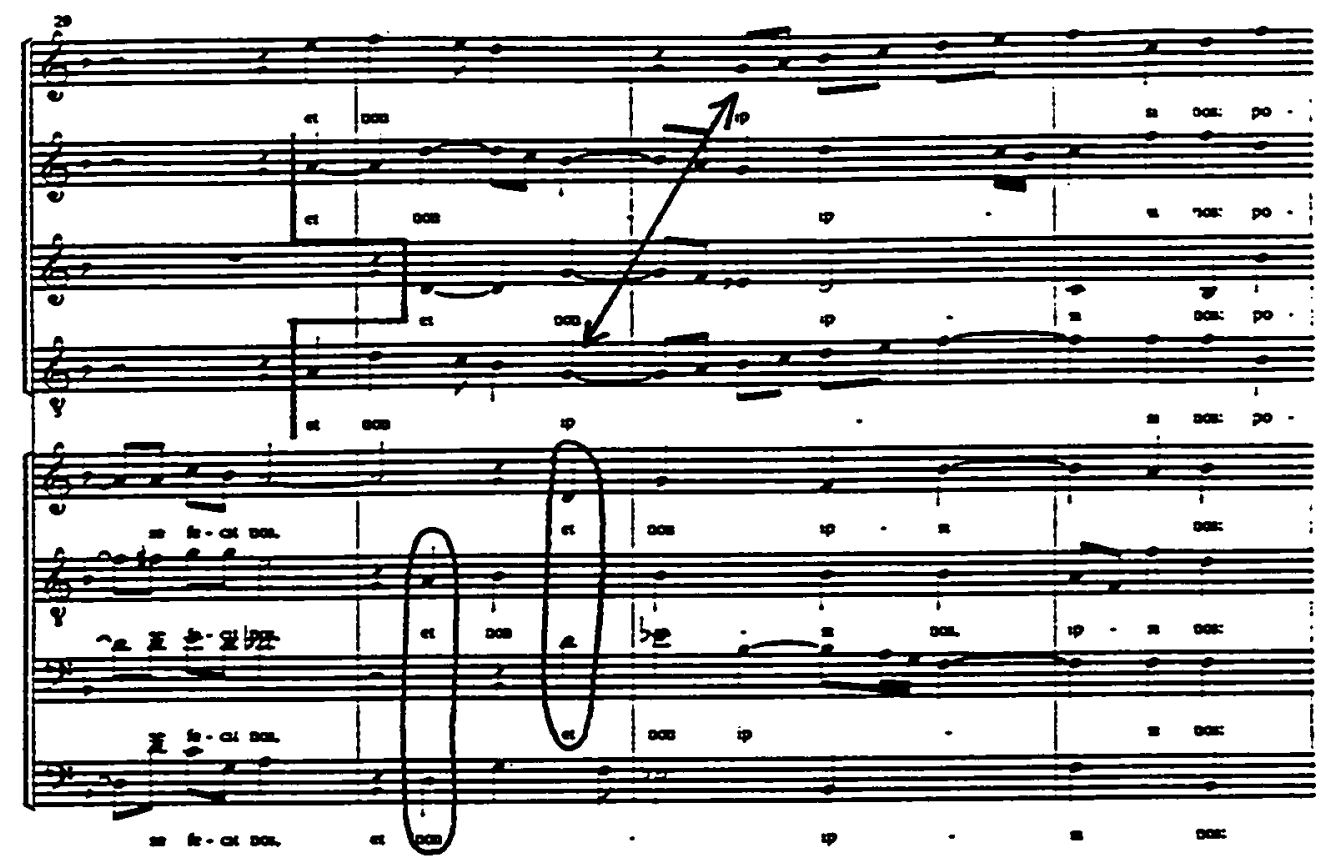

Ex. 16. Measures 29-32. Demonstrating the Complexities of Mankind.

Immediately following, in measure 33 Choir I simply states "we are his people and the sheep of his pasture." 38 This musical contrast is very effective and serves the meaning of the text very well. Measures 36-44 contain verse four sung by Choir I.

Choir II begins the text "laudate nomen ejus" (bless his name) at measure 45 in 3/4 time. Choir I responds by imitating this four measure phrase at the fifth. The phrase is then repeated a final time in tutti, landing

38This English translation is the most popular, however, "The people are his and the sheep in the pastures are his" is more accurate. The different translation changes its meaning significantly. 
alla brcoe in C. at measure 56. "Quoniam suavis est Dominus" (For the Lord is good) stays tutti to emphasize the text. Gabrieli continues with antiphonal singing beginning in measure 60 with a statement by Choir I, Choir II responding with exact imitation and tutti at measure 62.

The final section-spanning from measures 65 to 75 -is repeated in measures 76 to 85 and consists of the text "et usque in generationem et generationem veritas ejus" (and his faithfulness to all generations). This repetition creates a solid conclusion for the composition.

I Hans Leo Hassler begins with Cantus and Voice 5 of Choir I making the statement "Jubilate Deo" in the implied key of D minor. All four voices of Choir 1 then respond in measures 2 and 3, completing the phrase and cadencing in $\triangle$ Major. All of the phrases in the opening section (through measure 14) are energetic (made of short note values) and short (most are only one measure in length and none is longer than two) (Example 17).

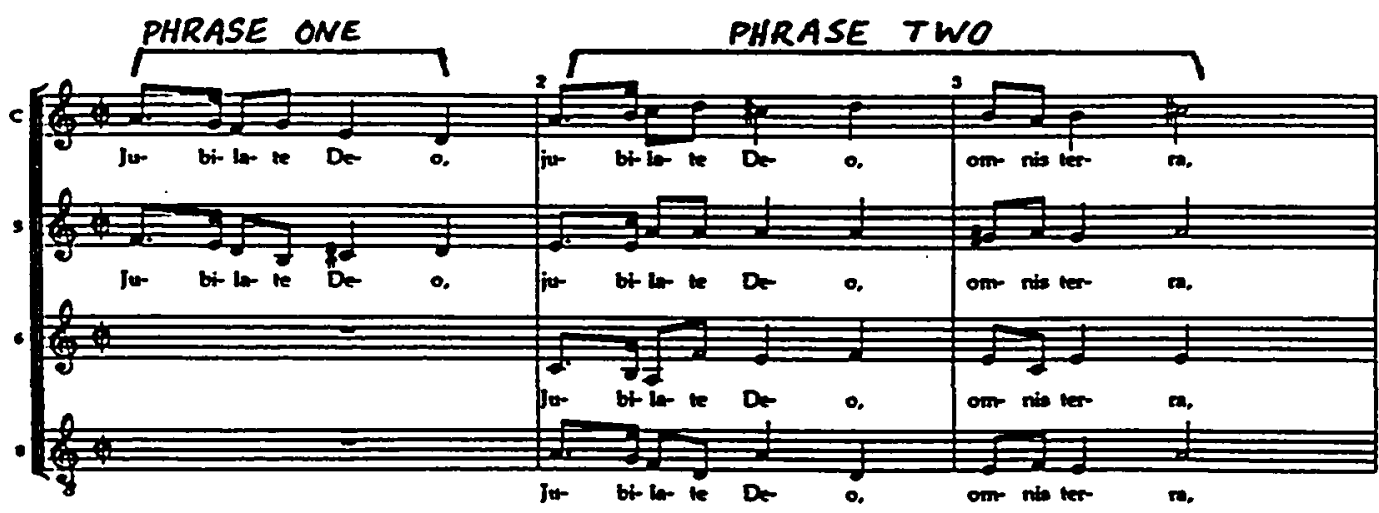

Ex. 17. Measures 1-3. Short Phrases and Quick Note Values. 
Choir II answers Choir I in measures $4-6$ using the same rhythmic patterns and similar intervallic movement. Overlapping antiphonal couplets begin at measure 7. In measure 10 one expects Choir II to respond to Choir I's statement, however Hassler abruptly "renews" the antiphonal section by having Choir I make a second statement of "Jubilate Deo" which is answered by Choir II and finally tutti in measure 12 . Measure 13 and 14 close this first section with an antiphonal couplet and tutti to the text "omnis terra."

Hassler sets the text "psalmum dicite nomini ejus" (sing to the glory of His name) to longer note values and 3/4 meter beginning with Choir I at measure 15. This phrase has no ornamentation and reflects the authority and majesty of its text through simple homophonic and melodic writing. The four vocal parts are scored closely together, creating chords which project authority in stark contrast to the preceding and following material. (Example 18).

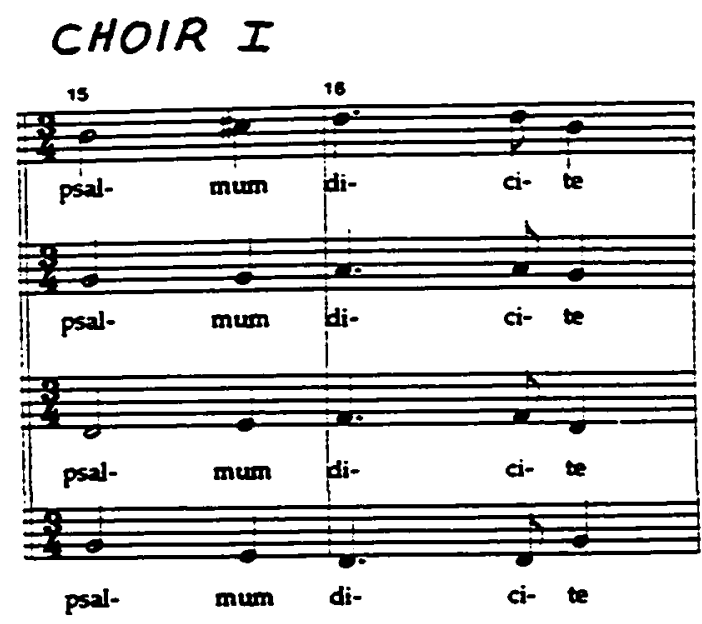

Ex. 18. Measures 15-16. Longer Note Values. 
Choir II responds to measures $15-18$ with exact imitation: the Altus has the melody at the fourth and the rhythm is imitated precisely. The same rhythmic pattern is used a third time as the choirs sing the phrase tutti (measures 22-24).

At measure 25 the time signature returns to alla breoc, the metric values are shortened and Choir I begins a series of antiphonal couplets. In measure 29 the text "dicite Deo" (declare to God) is sung antiphonally, however the pace is quickened by Choir II responding prior to the completion of the phrase by Choir I. Antiphonal singing continues through measure 37, closing with a tutti statement of "opera tua" (your works).

Choir II takes over at measure 37 with text which begins "Domine, in multitudine" (Lord, so numerous in your power). This section divides the composition in half and brings relief from the quick rhythmic patterns and alternating choir sequences which comprise the remainder of this composition. The entire composition consists of Choir I + Choir II + tutti combinations, the only exception being measures $37-47$ sung by Choir II. This section contains longer note values, begins homorhythmically with straight quarter notes, is almost void of dotted rhythms (with the exception of a few dotted-quarter, eight note patterns) and intervals greater than a third are rare. Antiphonal singing resumes in measure 47. Eighth note patterns return without dotted rhythms and voice exchange is used to create interest.

With measure 51 comes a meter change to $3 / 4$ time. The antiphonal exchanges continue, however longer note values (quarter and half notes) are used. Measures 52-60 have the following pattern: Choir I + Choir II + Choir I 
+ Tutti. The $3 / 4$ section is completed with a tutti Repeated Cadence to the text "et psallat tibi" (and they sing praises to you).

Measure 61 returns to fast rhythms, incorporating the use of eighth and sixteenth notes. In this measure Choir I makes a statement and in measure 63 Choir II imitates at the fourth. The immediate response is tutti and homorhythmic with the same text, "psalmum dicat nomini tuo" (sing priases to your name). This text is repeated two more times tutti to bring the composition to a final closing which repeats the words "nomini tuo" (your name) in measure 70-72. 


\section{Chapter 9}

\section{Conclusion}

Hans Leo Hassler's sacred polychoral motets Angelus ad pastores ait, Beati Omnes, and Jubilate Deo from the collection Sacri Concentus (1601) "represent Hassler's highest achievement in fusing German and Italian sacred styles." 39 The double-choir motets by Giovanni Gabrieli on the same texts represent two different periods in his development and level of skill: the 1587 publication Concert di Andrea et di Giooanni Gabrieli contained Angelus ad pastores ait and the 1597 publication Sacrae Symphoniae Liber I included Beati Omnes and Jubilate Deo. All six compositions used for analysis and comparison were composed after Hassler had studied in Venice and Gabrieli in Bavaria. Therefore, the likeness of the composers' travels, foreign experiences and shared mentors provided a basis for determining how their personal styles and tendencies compare. Hassler incorporated Italian traits into his Latin polychoral motets making them representative of both Germany and Italy while Gabrieli focused on maintaining and expanding the Italian characteristics learned from his uncle. This point has been made visible through an analysis of Hassler's Angelus ad Pastores Ait, Beati Omnes and Jubilate Deo-and comparing and contrasting them to double-choir motets by Giovanni Gabrieli based on similar texts.

In Hassler's compositions for double-choir one sees his careful consideration of the setting of the Latin text. Its inflection, nuance and meaning are heightened by the use of dialogue, spatial considerations, and

39John Hoffacker, "Hassler and the Italian Style," American Choral Review Journal of the American Choral Foundation, Inc. 31/2 (Spring 1989): 12. 
changing choir timbres through careful selection and combination of vocal ranges. His Germanic attentiveness to strict form is demonstrated along side his ability to utilize overlapping phrases when necessary to enhance text meaning and create musical interest.

Hans Leo Hassler further demonstrated a command of innovative Italian technique in his double-choir compositions through the effective use of V-I (tonic-dominant) relationships. He competently moves harmonically through the circle of fifths while also utilizing third relationships. This neither disrupts the musical flow nor detracts from the poetic content. Hassler's successful exploitation of V-I relationships and chromaticism made him progressive in the field of composition and his style is sometimes referred to as "pre-baroque." 


\section{SELECTED BIBLIOGRAPHY}

\section{BOOKS AND DISSERTATIONS}

Abraham, G., ed. The New Oxford History of Music Vol. 4: The Age of Humanism, 1540 - 1630. New York: Oxford University Press, 1968.

Anthon, Carl. "Music and Musicians in Northern Italy During the Sixteenth Century." Unpublished dissertation, Harvard University, 1943.

Arnold, Denis. Giovanni Gabrieli. London: Oxford University Press, 1974.

- Giovanni Gabrieli and the Music of the Venetian High Renaissance. London: Oxford University Press, 1980.

Bayes, J. R. "The Proposed use of Improvised Embellishments in the Instrumental Music of Giovanni Gabrieli: the Canzone and Sonate from the Sacrae Symphoniae of 1597." D.M.A. dissertation, University of Washington, 1978.

Bianconi, L. Music in the Seventeenth Century. Translated by David Bryant. New York: Cambridge University Press, 1987.

Borgir, T. The Performance of the Basso Continuo in Italian Baroque Music Studies in Musicology, no. 90. Ann Arbor: UMI Research Press, 1987.

Brett, Ursula. Music and ideas in Seventeenth Century Italy: the CazzatiArresti Polemic Edited by John Caldwell. A Garland Series. New York: Garland Publishing, Inc., 1989.

Brown, Howard Mayer. Music in the Renaissance. Englewood Cliffs, New Jersey: Prentice-Hall, Inc., 1976.

Brown, Howard Mayer and Sadie, Stanley, eds. Performance Practice: Music before 1600. The Norton/Grove Handbooks in Music. New York: W. W. Norton \& Company, 1989.

Bukofzer, Manfred. Music in the Baroque Era. New York: W. W. Norton, 1947. 
- Studies in Medieval and Renaissance Music. "The Beginnings of Choral Polyphony." New York: W. W. Norton, 1950.

Carver, Anthony. Cori Spezzati. Volume I: The Development of Sacred Polychoral Music to the Time of Schütz. Cambridge: Cambridge University Press, 1988.

- "The Development of Sacred Polychoral Music to 1850." (dissertation, University of Birmingham, 1980).

Clough-Leighter, H., ed. The A Cappella Singer. Boston: E. C. Schirmer Music Company, 1936.

Colunga, Alberto and Turrado, Laurentio, eds. Biblia Sacra juxta Vulgatam Clementinam. Nova Editio. Matriti: Biblioteca de Autores Cristianos, 1959.

Dart, T. The Interpretation of Music New York: Hutchinson's University Library, 1954.

Degrada, Francesco., ed. Andrea Gabrieli e il suo tempo. Studi di Musica Veneta, no. 11. Firenze: Leo S. Olschki, 1987.

Donington, Robert. The Interpretation of Early Music London: Faber and Faber, 1963.

Einstein, Alfred. The Italian Madrigal. Translated by Alexander $\mathrm{H}$. Krappe, Roger Sessions and Oliver Strunk. Princeton: Princeton Universtiy Press, 1949.

Elley, Derek International Music Guide. London: Tantivy, 1978.

Ephros, Gershon, ed. Cantorial Anthology of Traditional and Modern Synagogue Music. Volume I. New York: Bloch Publishing Company, 1946.

Fenlon, I., ed. Music in Medieval and Early Modern Europe. New York: Cambridge University Press, 1981.

Flower, J. A. "Giovanni Gabrieli's Sacrae Symphoniae." Ph.D. dissertation, University of Michigan, 1955. 
Fromme, Arrold. "The Compositions for Three Choirs in the Canzoni et Sonate (Venice, 1615) of Giovanni Gabrieli: a Critical and Performance Edition." Ph.D. dissertation, New York University, 1980.

Gabrieli, Giovanni. Opera Omnia. Corpus Mensurabilis Musicase, 12. Foreword by D. Arnold. Dallas: American Institute of Musicology, 1959.

Hassler, Hans Leo. Sämtliche Werke. Edited by C. Russell Crosby Jr. Forward by Joseph Auer. Vol. 5 and 6: Sacri Concentus Für Vier Bis Zwölf Stimmen. Wiesbaden: Breitkopf \& Härtel, 1961.

Houle, G. Meter in Music, 1600-1800: Performance, Perception and Notation. Music-Scholarship and Performance. Bloomington: Indiana University Press, 1987.

Jarvis, Sister M. E. "The Latin Motets of Hans Leo Hassler." Ph.D. dissertation, University of Rochester, 1959.

Jeffers, Ron, ed. Translations and Annotations of Choral Repertoire, Volume 1: Sacred Latin Texts. Corvallis, Oregon: Cascade Printing Company, 1988.

Kenton, Egon. 1967. Life and Works of Giovanni Gabrieli. Musicaological Studies and Documents. Armen Carapetyan, editor. American Institute of Musicology, 1967.

Kimmel, William Breyfogel. Polychoral Music and the Venetian School. Rochester: University of Rochester Press, 1954.

Knighton, Tess and Fallows, David, eds. Companion to Medieval and Renaissance Music. New York: Schirmer Books, 1992.

Mason. W. E. The Architecture of St. Mark's Cathedral and the Venetian Polychoral Style: a Clarification. Studies in Musicology...in memory of Glen Haydon, ed. J. W. Pruett. Chapel Hill: The Uriversity of North Carolina Press, 1969.

Ongaro, Giulio Maria. "The Chapel of St. Mark's at the Time of Adrian Willaert (1527-1562): A Documentary Study." Ph.D. dissertation, The University of North Carolina at Chapel Hill, 1986. 
Reese, Gustave. Music in the Renaissance. Revised edition. New York: W. W. Norton \& Company, Inc., 1959.

Roche, J. Northern Italian Church Music in the age of Monteverdi. Oxford: Clarendon Press, 1984.

Ruggles, M. J. "Hans Leo Hassler's Psalmen und Christliche Gesang, 1607: A study of 52 chorale motets, as influenced by the Netherlands, German and Venetian styles of composition, with performing editions of 10 selected motets." D.M.A dissertation, The University of Oklahoma, 1989.

Selfridge-Field, E. Venetian Instrumental Music from Gabrieli to Vivaldi. New York: Praeger Publishers, 1975.

Simi, David. The Use of 20th Century Instruments in Three Selected Polychoral Motets by Giovanni Gabrieli. M.A. thesis, San Jose State University, 1977.

Strunk, Oliver, ed. Source Readings in Music History. New York: W. W. Norton, 1950.

Thomson, James. Music through the Renaissance. Dubuque: W. M. C. Brown Company, Inc., 1959.

Tomlinson, Gary. Monteverdi and the End of the Renaissance. Berkeley: University of California Press, 1987.

Ultan, Lloyd. Music Theory: Problems and Practices in the Middle Ages and Renaissance. Minneapolis: University of Minnesota Press, 1977.

Woodworth, G. W. Texture Versus Mass in the Music of Giovanni Gabrieli. Essays on Music in Honor of Archibald Thompson Davison.

Cambridge, Mass: Cambridge University Press, 1957.

\section{PERIODICALS}

Aldrich, P. "An Approach to the Analysis of Renaissance Music." Musical Review 30/1 (1969): 1-21.

Arnold, Denis. "Ceremonial Music in Venice at the Time of the Gabrielis." Proceedings of the Royal Musical Association 32 (1955-6): 47. 
- . "Con ogni sorte di stromenti: Some Practical Suggestions." Brass Quarterly 2 (1959): 99.

-. "Monteverdi's Church Music: Some Venetian Traits." Monthly Musical Record 88 (May-June 1958): 84-6.

-. "Music at a Venetian Confraternity in the Rennaissance." Acta Muicologica: Revue de la Société Internationale de Musicologie 37/1-2 (1965): 62-72.

—. "Music at the Scuola di San Rocco." Music and Letters 11 (1969): 229.

- "The Second Venetian Visit of Heinrich Schütz." Musical Quarterlv 71/3 (1985): 359-74.

- "The Significance of Cori Spezzati ." Music and Letters, 11 (1969): 4.

- The Significance of Cori Spezzati ." Music and Letters 40 January 1959): 4-14.

-2. "Towards a Biography of Giovanni Gabrieli." Musica Disciplina 15 (1961): 199-207.

Bedbrook, G. S. "The Genius of Giovanni Gabrieli." Musical Review 8 (1947): 91.

Bonta, Stephen. "The Use of Instruments in Sacred Music in Italy 1560-1700." Early Music 18/4 (November 1990): 519-530.

Boorman, S. "Text Problems in Renaissance Motets." Music Teacher 111 (March 1970): 272-3.

Bradshaw, M. C. "The Influence of Vocal Music on the Venetian Toccata." Musica Disciplina 42 (1988): 168-76.

Bryant, David, ed. "Concerti di Andrea and di Giovanni Gabrieli." Early Music 19/1 (1991): 126-7.

- . The Cori Spezzati of St. Mark's: Myth and Reality." Early Music 1 (1981): 165-86.

Cardamone, Donna G. "Canzone Villanesche alla Napolitana and Villotte: Adrian Willaert and His Circle." Early Music 8/4 (1980): 538, 541. 
Carey, Frank "Composition for Equal Voices in the Sixteenth Century." lournal of Musicology 9/3 (1991): 300-342.

Carter, Tim. "Concerti di Andrea at di Giovanni Gabrieli." Edited by David Bryant. Early Music 19/1 (February 1991): 126-7.

Carver, Anthony. "Polychoral Music a Venetian Phenomenon?" Roval Musical Association Proceedings 108 (1981-1982): 1-24.

Charteris, R. "The Performance of Giovanni Gabrieli's Vocal Works: Indications in the Early Sources." Music \& Letters 71/3 (1990): 336-51.

Charteris, R. and Haberkamp, G. "Regensburg, Bischöfliche. Zentralbibliothek, Butsch 205-210: a Little Known Source of the Music of Giovanni Gabrieli and His Contemporaries." Musica Disciplina 43 (1989): 195-249.

Cliff, S. and Davis, J., ed. "A Selected Annotated Bibliography of Source Materials Pertaining to 16 th and 17 th Century Performance Practices." lournal of the International Trumpet Guild 11/4 (1987): 19-20.

Conlon, Joan C. "Early Instruments and Choral Music." Choral Journal 20 (September 1979): 5-11.

Cox, Dennis K. "The Fusion of National Choral Idioms in the Renaissance." American Choral Review 29/2 (Spring 1987): 3-8.

Cummings, Anthony M. "Toward an Interpretation of the 16th Century Motet." American Musicological Society 34/1 (1981): 43-59.

Cooper, T. G. "Two Neglected Aspects of Renaissance Motet Performance Practices." Choral Journal 27/4 (1986): 9-12.

D'Alessi, G. "Precursors of Adriano Willaert in the Practice of Coro Spezzato." American Musicological Society 5 (1950): 187.

Dickinson, A. E. F. "A Forgotten Collection: a Survey of the Weckmann Books." Musical Review 17 (1956): 97.

Elias, Cathy A. "Musical Performance in 16th-Century Italian Literature: Straparola's Le Piacevoli Notti." Early Music 17 (May 1989): 161-73. 
Federhofer, H. "Alessandro Tadei, a Pupil of Giovanni Gabrieli." Musica Disciplina 6 (1952): 115-31.

Fenlon, L. “St. Mark's Before Willaert." Early Music 21/ 4 (1993): 546-8.

Fisher, Gary. "Renaissance Vocal Technique for the Choral Conductor." Choral Journal 29/1 (1988): 15-19.

Gable, Frederick K. "St. Gertrude's Chapel, Hamburg, and the Performance of Polychoral Music." Early Music 15 (1987): 229.

Golos, J. "Niewinnosc Panie moie czy lo Son Ferito?" Ruch Mus 10/16 (1966): 19.

Guentner, F. J. "Word Painting in the Renaissance Mass and Motet." Catholic Choirmaster 40 (Fall 1954): 99-102.

Hardouin, P. "Note sur les Orgues de Saint Marc a Venise au Temps des Gabrielis." Organ Yearbook 10 (1979): 156-9.

Harran, D. "Directions to Singers in Writings of the Early Renaissance." Revue Belge de Musicologie 41 (1987): 45-61.

Hoffacker, John. "Hassler and the Italian Style." American Choral Review Journal of the American Choral Foundation, Inc. 31/2 (Spring 1989): 734.

Hudson, F. "Giovanni Gabrieli's Motet a 15, In Ecclesiis, from the Svmphoniae Sacrae." Musical Review 24 (1963): 130.

Kenton, Egon F. "The Instrumental Works of Giovanni Gabrieli, the Late Period." American Musicological Society 9 (Fall 1956): 234-6.

- "The Late Style of Giovanni Gabrieli." Musical Quarterly 48 (1962): 427-43.

_- "Towards a Biography of Giovanni Gabrieli." Musica Disciplina 15 (1961): 199.

Kirchberg, K. and Wittgen, H., eds. "Gedenkstein fuer Hans Leo Hassler." Musikhandel 20/8 (1969): 372. 
Klostermaier, D. "Heinrich Schütz, 1585-1672." The Canada Music Book 5 (Autumn-Winter 1972): 167-77.

Krummacher, F. "Fränkische Figuralmusik im 17. Jarhundert und ihr Verhältnis zur Reformation." Gottesdienst und Kirchenmusik n1 (1968): 11-12.

Layer, A. "Die ersten Augsburger Jahre Hans Leo Hasslers." Musikforschung 8/ 4 (1955): 452-5.

Lewis, Mary S. "Zarlino's Theories of Text Underlay as Illustrated in his Motet Book of 1549." Notes 42/2 (December 1985): 239-267.

Martens, M. "Heinrich Schütz and Giovanni Gabrieli." American Organist 19 (October 1985): 83-6.

Mehl, J. G. "Hans Leo Hassler von Nürnberg (1564-1612)." Gottesdienst und Kirchenmusik n5 (1964): 179-83.

Mendel, Arthur. "Pitch in the 17th and Early 18th Centuries." Musical Quarterly 34 (1978): 28, 199, 336, 575.

- "Pitch in Western Music Since 1500." Acta Musicologica: Revue de la Société Musicologie 50/1 (1948): 328.

Moore, James $\mathrm{H}$. "The Vespero delli Cinque Laudate and the Role of Salmi Spezzati at St. Mark's." Iournal of the American Musicological Society 34 (1981): 249-278, n2.

Morill, Martin. "The Biographies of Andrea and Giovanni Gabrieli." Musikhandel 3 (1983): 101.

Moser, H. J. "Das Opus Sacrum des Vierhundertiahrigen Hans Leo Hassler." Musik und Kirche 34/6 (1964): 269-71.

Music, David. "Giovanni Gabrieli." Journal of Church Music 23/2 (February 1981): $2-4$

Owens, Jessie A. "Music Historiography and the Definition of Renaissance." Notes 47/ 2 (December 1990): 305-330. 
l'anetta, V. "Toccatas Carrying Conflicting Attributions to Sweelinck and Hassler." Tijdschrift van de Vereniging voor Nederlandse Muziekgeschiedenis 42/2 (1992): 90-130.

Pesce, D. "A Revised View of the 13th Century Latin Double Motet." American Musicological Society 40/3 (1987): 405-42.

Razzi, Fausto. "Polyphony of the Seconda Prattica: Performance Practice in Italian Vocal Music of the Mannerist Era." Early Music 8/3 (1980): 298311.

Reimann, H. "Hans Leo Hassler." Der Evangelische Kirchenchor 16/5 (1962): 66-70.

Riemer, O. "Simpliciter und Fugneis." Gottesdienst und Kirchenmusik n5 (1964): 184-94.

Selfridge-Field, E. "Bassano and the Orchestra of St. Mark's." Early Music 4/2 (1976): 152-8.

Selfridge-Field, E. "Gabrieli and the Organ." Organ Yearbook 7 (1977): 2-19.

Sharp, G. "A Venetian Janus: Monograph on Giovanni Gabrieli." Journal of Church Music 2/29 (1969): 10-12.

Stevens, Denis. "Choral Dialogues of the Renaissance." The Musical Times 122/1644 (October 1981): 667-70.

Tarr, E. H. "A Selected Annotated Bibliography of Source Materials Pertaining to 16th and 17th Century Performance Practices: Additional References." Lournal of the International Trumpet Guild 12/2 (1987): 56-7.

Termini, O. "Great Teachers in Music History." American Music Teacher 43 (January 1994): 20-23.

"The Italian Works of Hans Leo Hassler." American Choral Review 31/2 (Spring 1989).

Tolin, Craig. "An Outline of Performance Practices in Late Fifteenth - and Early Sixteenth - Century Sacred Choral Music." Choral Journal 27 (October 1986): 5-14. 
Wetzler, R. "The A Cappella Myth." Journal of Church Music 8 (January 1966): 10-11.

\section{DICTIONARIES ANDENCYCLOPEDIAS}

Baker's Biographical Dictionary. 8th ed., Edited by Nicolas Slonimsky. "Hans Leo Hassler."

Scholes, Percy. The Oxford Companion to Music 10th ed., Edited by John Owen Ward. "Hans Leo Hassler."

The New Grove Dictionary of Music and Musicians, 1980 ed., Edited by Stanley Sadie. "Hans Leo Hassler." 


\section{APPENDIX A}

Text Translations

The Latin texts are presented here as they appear within their corresponding polychoral motet. The second line consists of a word-for-word translation. The third line is a poetic translation taken from the Revised Standard Version of the Holy Bible.

\section{Angelus ad Pastores}

Luke 2: 8-11

Angelus / ad / pastóres / ait:

Angels / to / shepherds/ said:

The Angel said unto the Shepherds:

Annúntio / vóbis / gáudium / magnum:

Announce/ to you/ joy / great:

Behold, I bring you joyful tidings:

quía / nátus / est / vóbis / hódie / Salvátor / múndi ${ }^{1}$, alleluia, alleluia. because/ born / is / to you/ today / Savior / world, alleluia, alleluia. for unto you is born this day the world's Redeemer, alleluia, alleluia.

Giovanni Gabrieli continues with the Greater Doxology:

Gloria / in / excelsis / Deo:

Glory / in / highest / to God:

Glory to God in the highest:

et / in / terra / pax / hominibus / bonae / voluntatis, and / on / earth/peace / to men / of good/ will, and on earth peace to men of good will,

1The translation for mundi can also include the heavens, sky and firmament in addition to the earth. 


\section{Angelus ad Pastores continued}

alleluia, / alleluia.

alleluia, / alleluia.

alleluia, alleluia.

\section{Psalm 128: 1-6}

1 Canticum / graduum.

1 Song (of) / a walking pace.

1 A song of ascents.

Beati / omnes 2 / qui / timent / Dominum, Bless / all / who / fear / the Lord, Blessed is every one who fears the Lord,

Qui / ambulant 3 / in / viis / eius.

Who / walk / in / sight / his.

Who walk in his ways!

2 Labores / manuum / tuarum / quia / manducabis,

2 Labor / hand / in a manner that you / the reason for / eat,

2 You shall eat the fruit of the labor of your hands;

Beatus / es, / et / bene / tibi / erit.

Bless / is, / and / goodness / yours / will be.

You shall be happy, and it shall be well with you.

3 Uxor / tua / sicut / vitis / abundans,

3 Wife / your / will be like / grapevine / abundant,

3 Your wife will be like a fruitful vine,

2Omnis or omnes translates to "all" or "the whole" especially refering to the universe.

3This means to walk leisurely, for pleasure or for exercise, each lending itself to different interpretations. 


\section{Psalm 128: $1-5$ continued}

In / lateribus / domus / tuae.

In / (of) brick / house / your.

Within your house.

Filii / tui, / sicut / novellae / olivarum, Sons / your, / will be like / young / olive trees, Your sons, will be like olive shoots,

In / circuitu / mensae / tuae.

In / a circle around / table / your.

Around your table.

4 Ecce $^{4}$ / sic / benedicetur 5 / homo

4 Behold! / So / beneficiary / man

4 Lo, thus shall the man be blessed

Qui / timet / Dominum.

Who / fears / the Lord.

Who fears the Lord.

5 Benedicat / tibi / Dominus / ex / Sion,

5 Fulfillment (be) / yours / close at hand / from / Zion,

5 The Lord bless you from Zion!

Et / videas / bona / Jerusalem / omnibus / diebus / vitae / tuae; And / view / good / Jerusalem / all / days of / vital / your; And may you see the prosperity of Jerusalem all the days of your life;

6 Et / videas / filios / filiorum / tuorum,

6 And / view / son / of sons / your,

6 And may you see your children's children!

${ }^{4} \mathrm{Ecce}$ is a dramatic reference to something which is usually not present.

$5_{\text {It }}$ is implied here that man is the beneficiary of the Lord's good will. 


\section{Psalm 128: 1-6 continued}

Pacem / super / Israel. l'cace / upon / Isracl. Peace be upon lsrael.

\section{Psalm 66: 1-4}

1 Jubilate / Deo, / omnis / terra:

1 Wild shouting / God, / all / earth:

1 Make a joyful noise to God, all the earth:

2 Psalmum6 / dicite / nomini / ejus;

2 (the) Psalms / declare / name / (to) your;

2 Sing to the glory of his name;

Date / gloriam / laudi / ejus.

Give / glory / praise / (to) you.

Give to him glory and praise.

3 Dicite / Deo: / Quam / terribilia / sunt / opera / tua, / Domine! 3 Declare /(to) God: / How / terrible / are / works / your, / Lord!

3 Say to God: "How terrible are thy deeds, (Lord)!

In / multitudine / virtutis / tuae / mentientur / tibi / inimici / tui. In / numerous / virtues / your / enemies / yours/ hateful to / you. So great is thy power that thy enemies cringe before thee,

4 Omnis / terra / adoret / te, / et / psallat / tibi;

4 All / earth / worships / you, / and / sings (to) / you;

4 All the earth worships thee, and they sing praises to thee,

Psalmum / dicat / nomini / tuo. (the) Psalms / declare / name / your. Sing praises to thy name."

GThe suffix -um makes this a noun. 
Psalm 100: 1-5

1 Jubilate / Deo / omnis / terra,

1 Wild shouting / (to) God / all / earth,

1 Make a joyful noise to the Lord, all the lands!

2 Servite / Domino / in / laetitia;

2 Serve / the Lord / with / gladness;

2 Serve the Lord with gladness!

Introite/ in / conspectu / ejus, Enter / into / range of sight / his, Come into his presence with singing,

3 In / exultatione: / scitote / quoniam / Dominus / ipse / est / Deus, 3 With / jubilation: / know / that / the Lord / himself / is / God,

3 Know that the Lord is God!

ipse / fecit / nos, / et / non / ipsi / nos:

himself / made / us, / and / not / him / we:

It is he that made us, and we are his;

[It is he that made us, and not us him;]

populus / ejus, / et / oves / pascue / ejus;

people / his, / and / sheep / of pasture / his;

we are his people, and the sheep of his pasture;

4 Introite / portas / ejus / in / confessione, / atria / ejus / in

4 Enter / gates / his / with / admission of guilt / courts / his / with

4 Enter his gates with thanksgiving, and his courts with praise;

hymnis; / confitemini / illi: / laudate / nomen / ejus: singing; / confess / there:/ praise / name / his: praise; give thanks to him, bless his name:

5 quoniam/ suavis / est / Dominus, / in / aeternum / misericordia / ejus, 5 because / gracious / is / the Lord / for / eternal / compassion / his, 5 For the Lord is good; his steadfast love endures forever,

et / usque / in / generationem / et / generationem / veritas / ejus. and / completely/with / generations / and / generations / truth / his. and his faithfulness to all generations. 


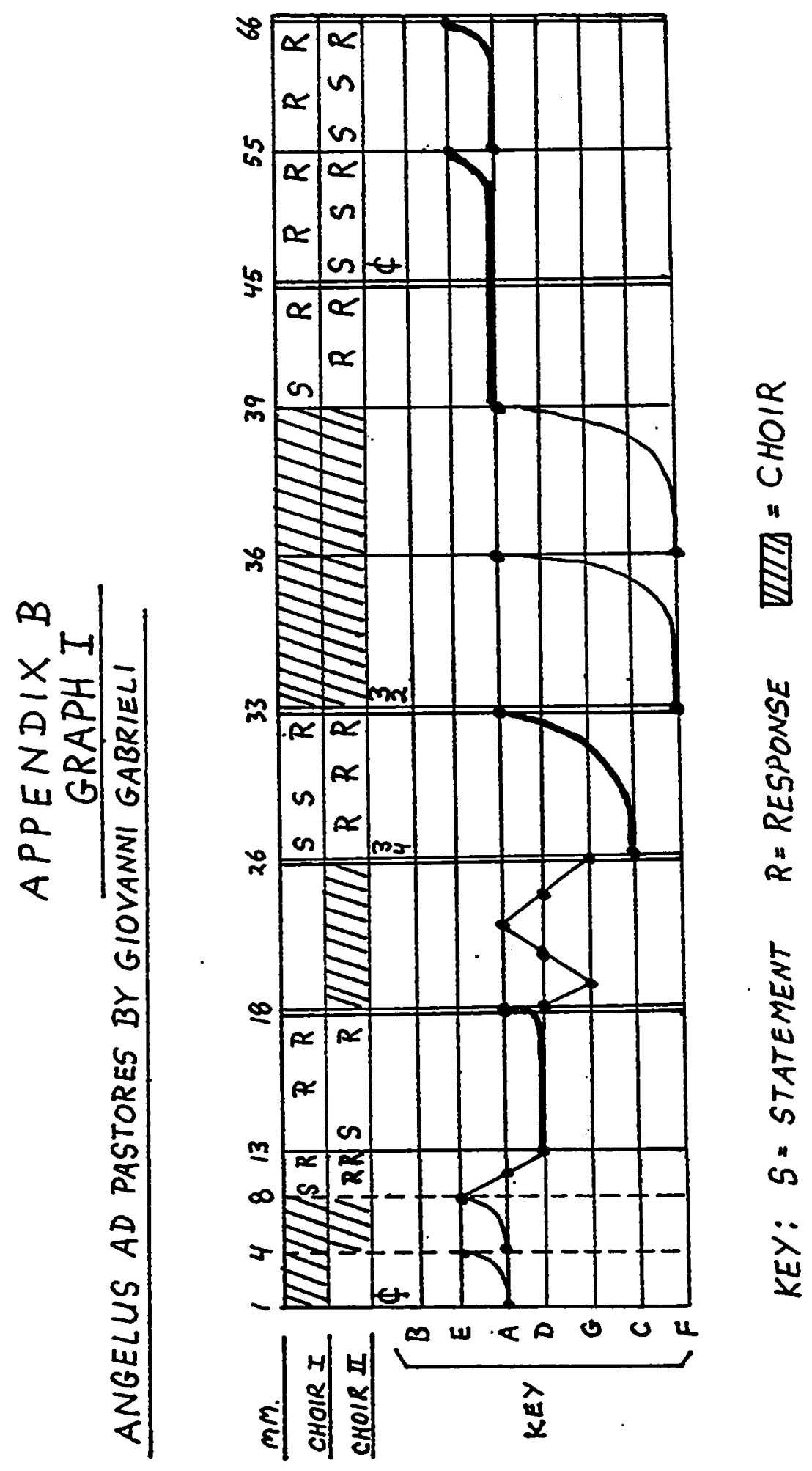




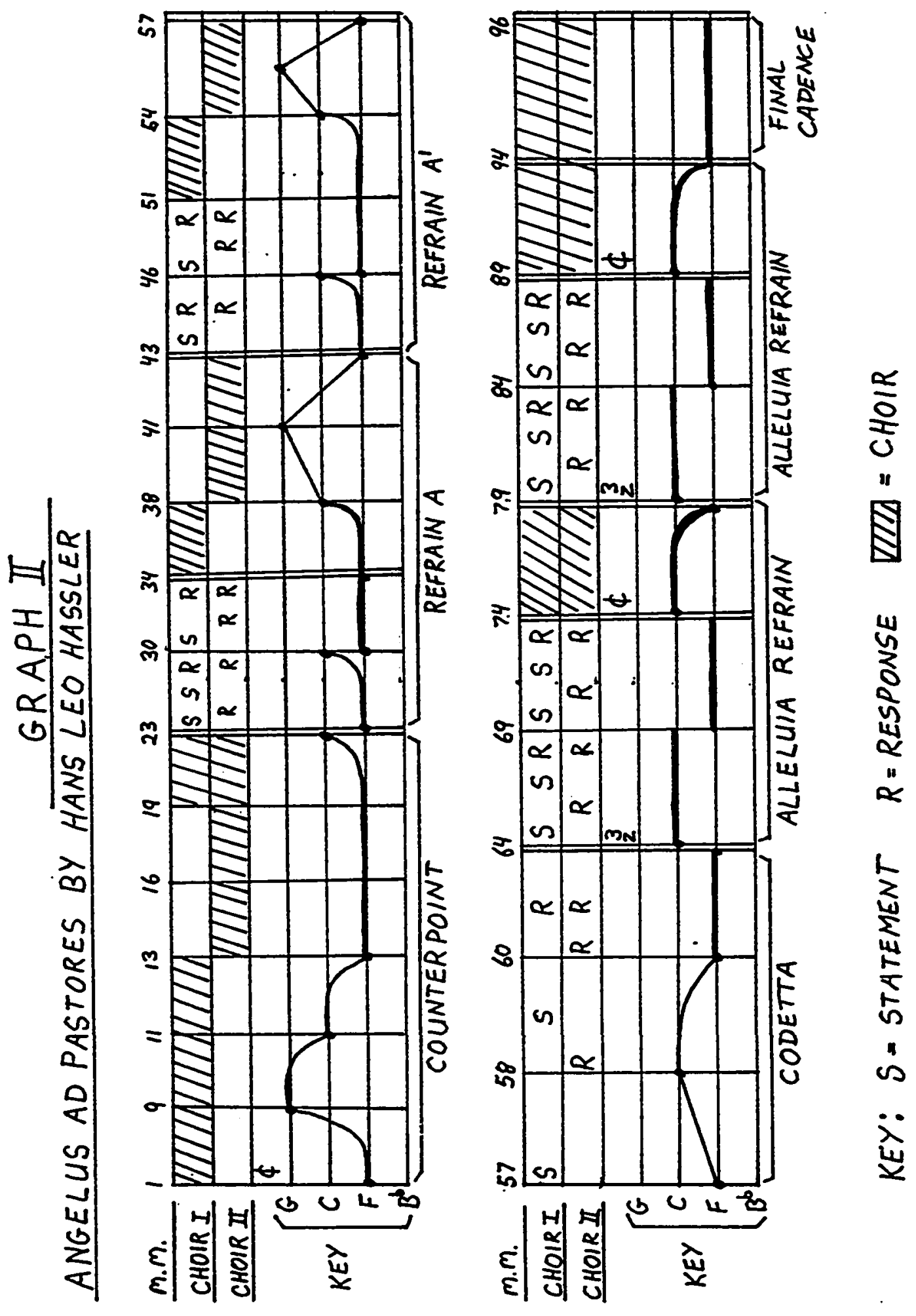




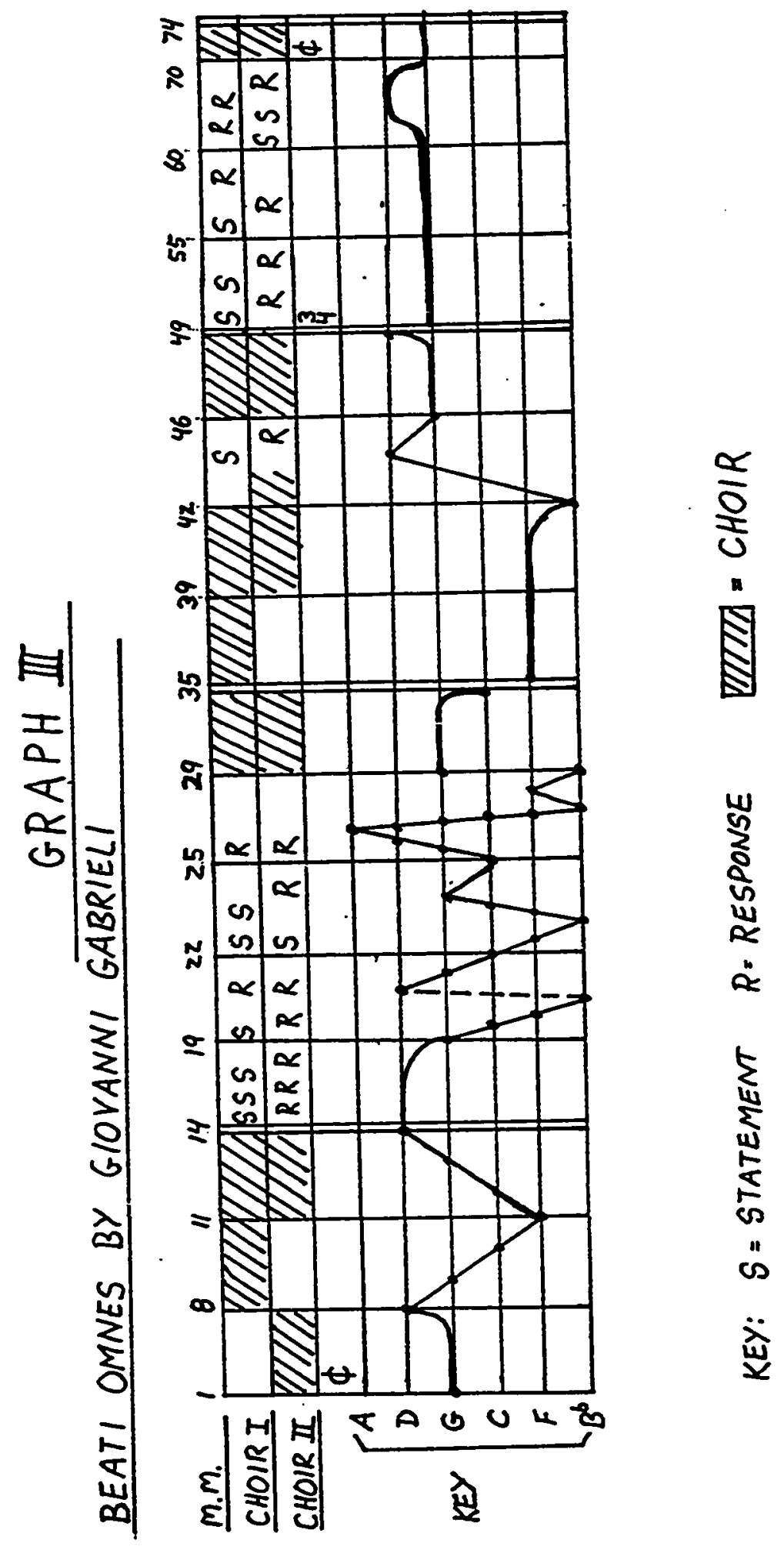




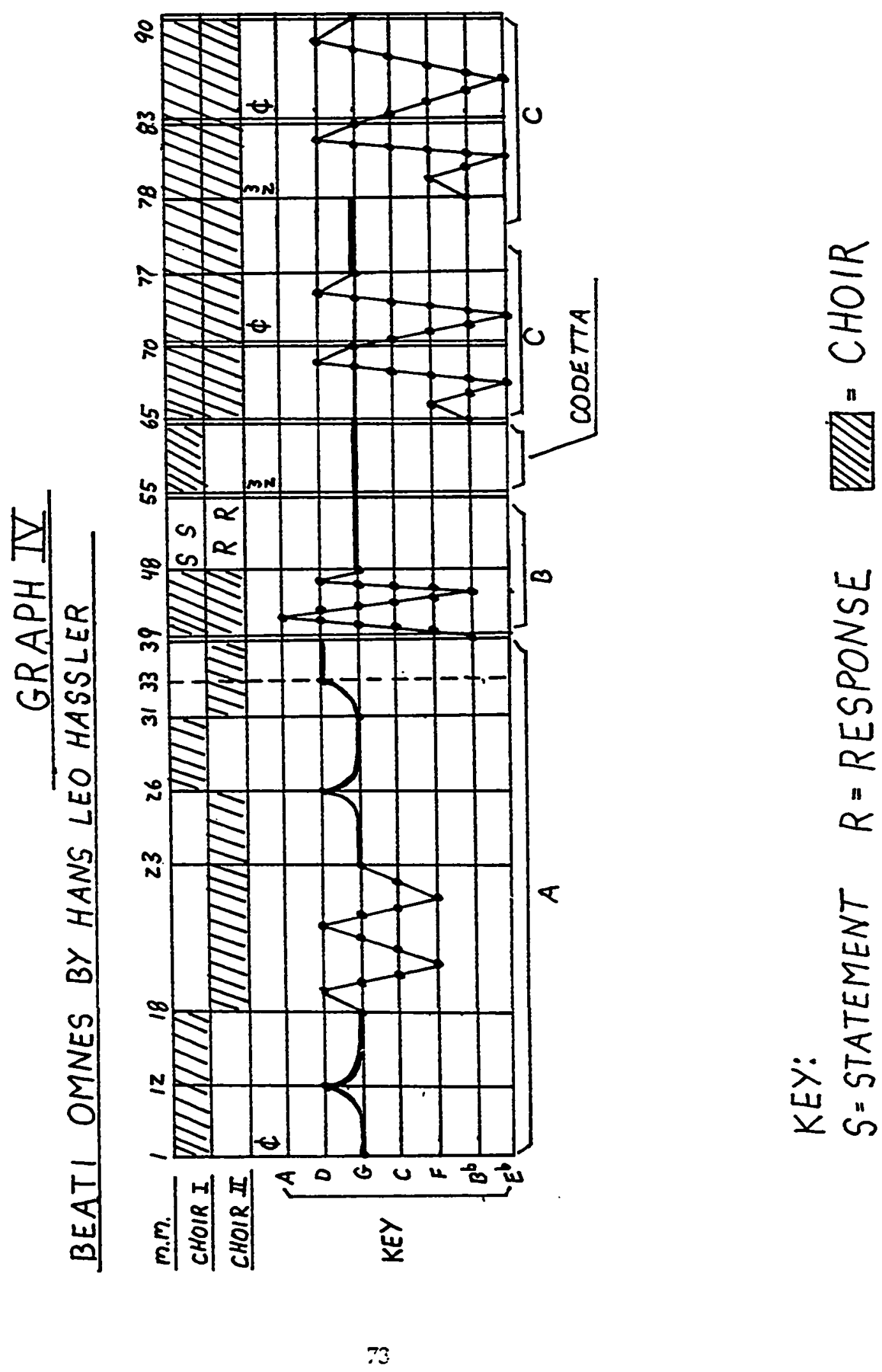




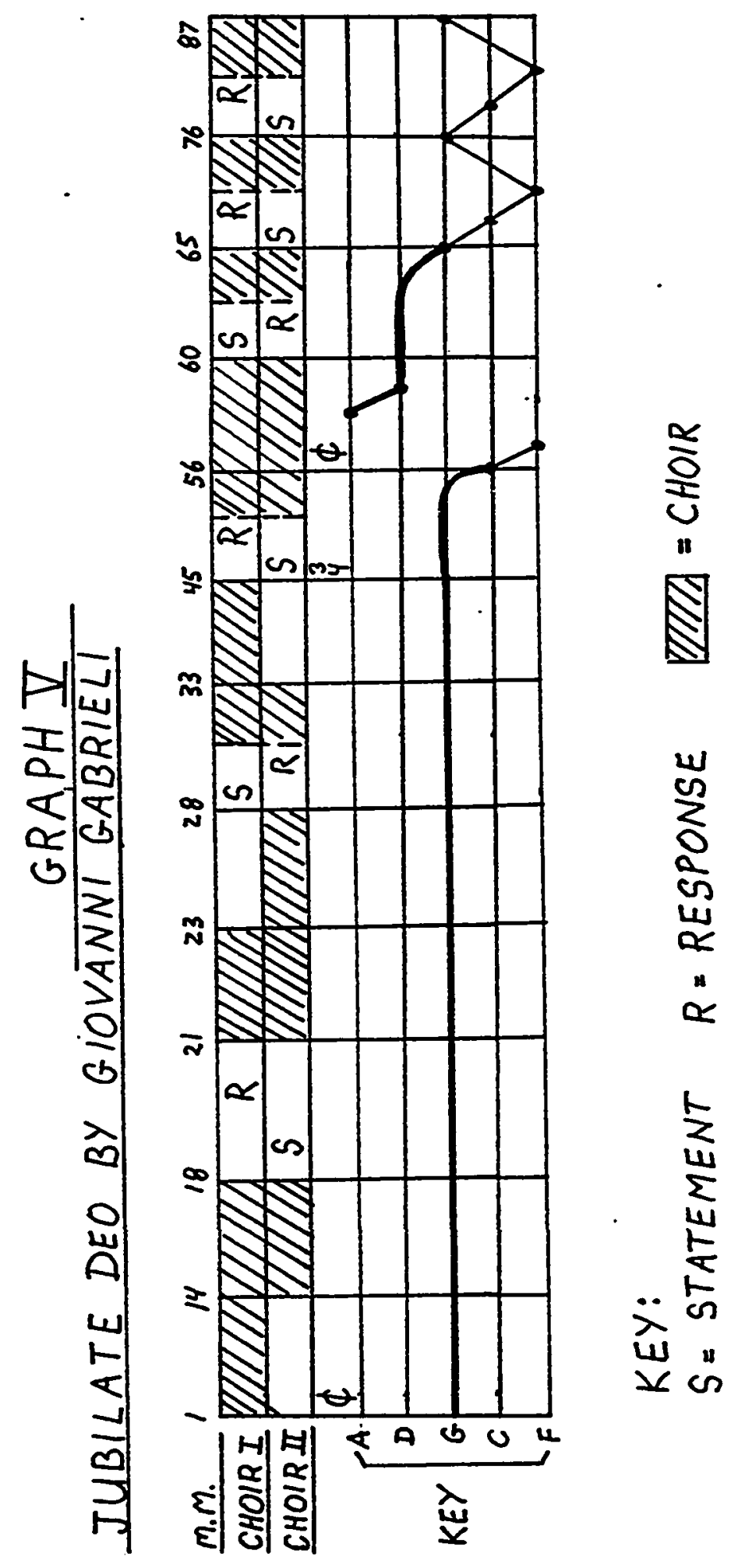




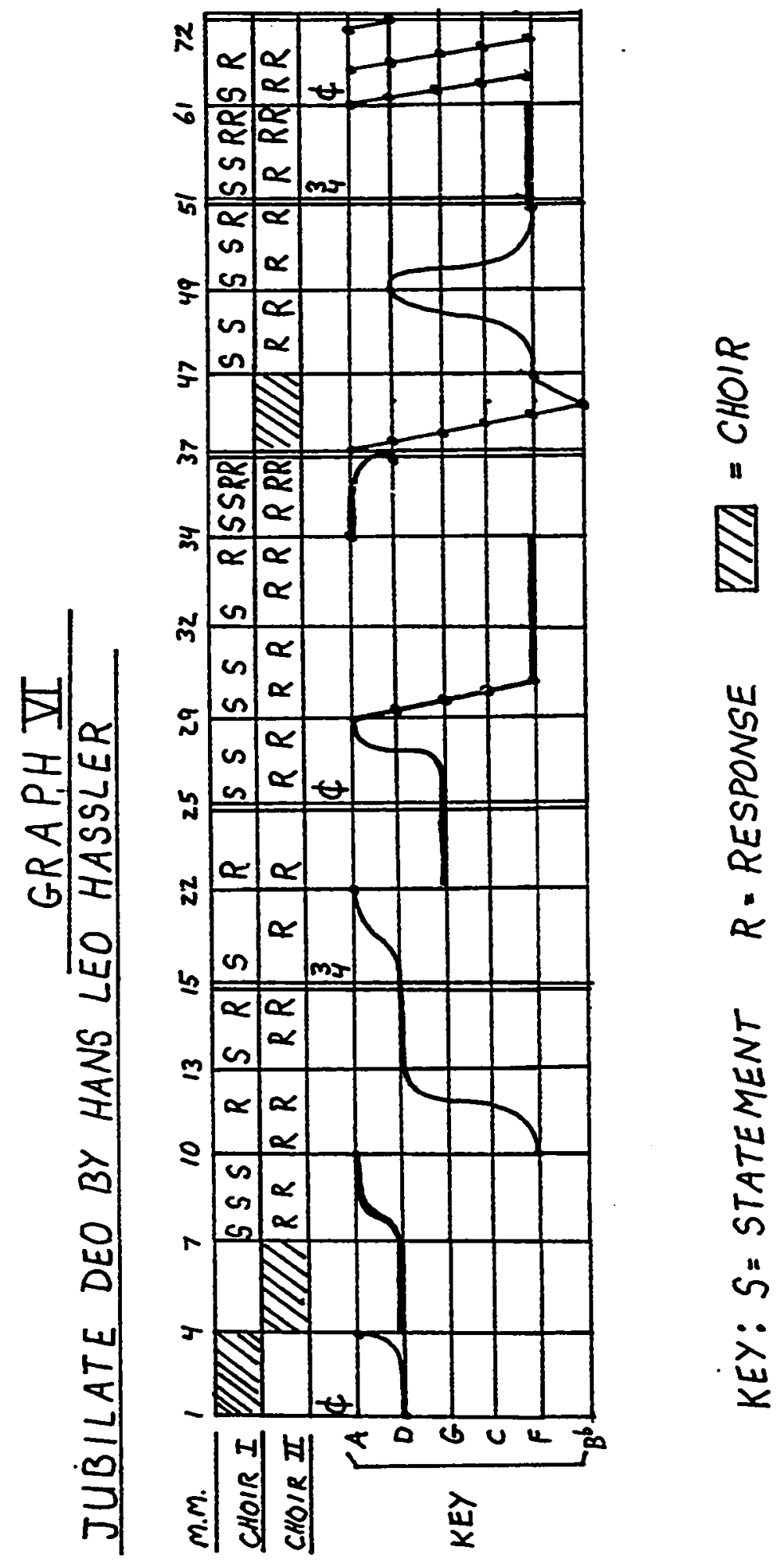




\section{Angelus Ad Pastores}

Luke 2:8-11

Giovanni Gabrieli ed. Mark Swope
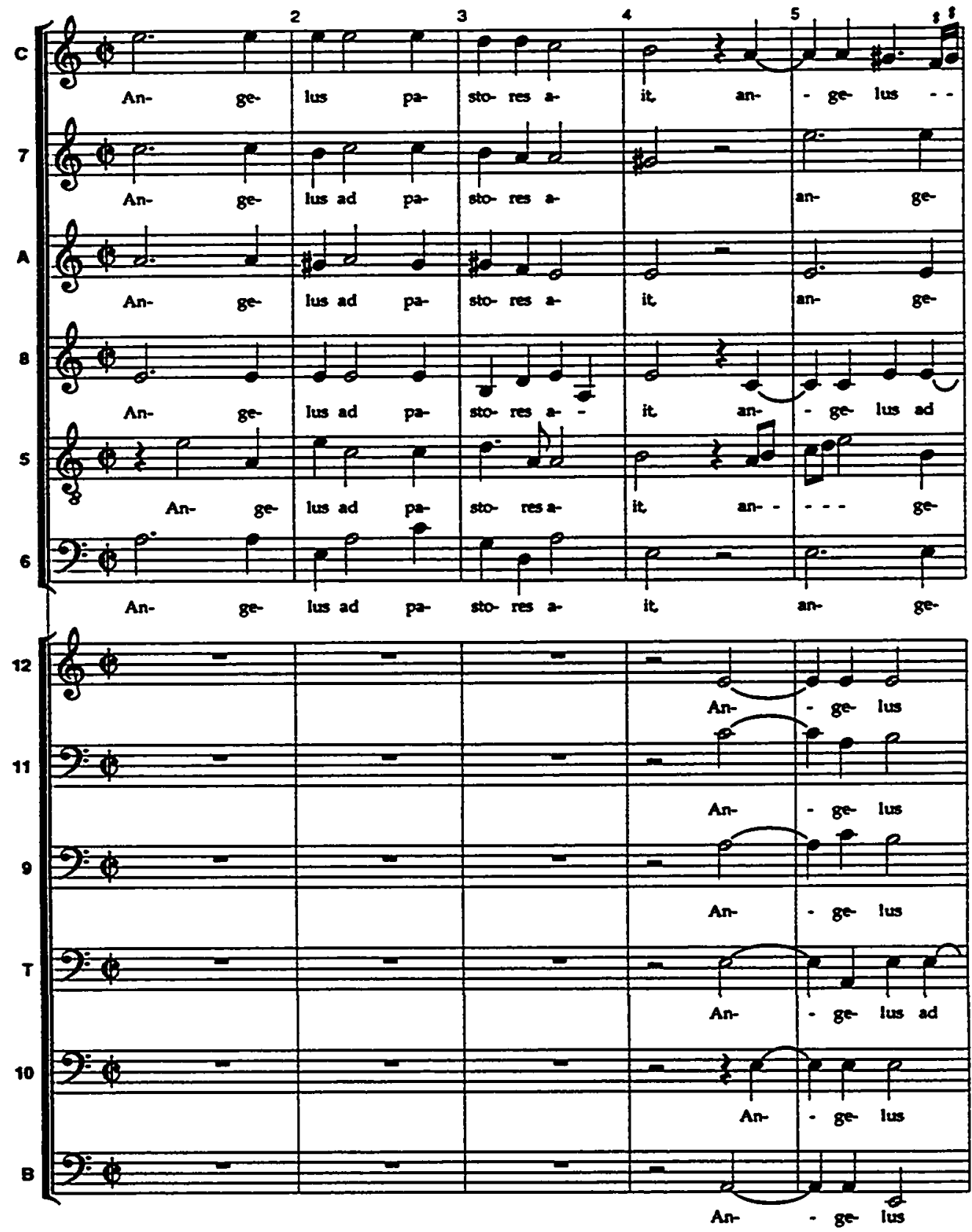


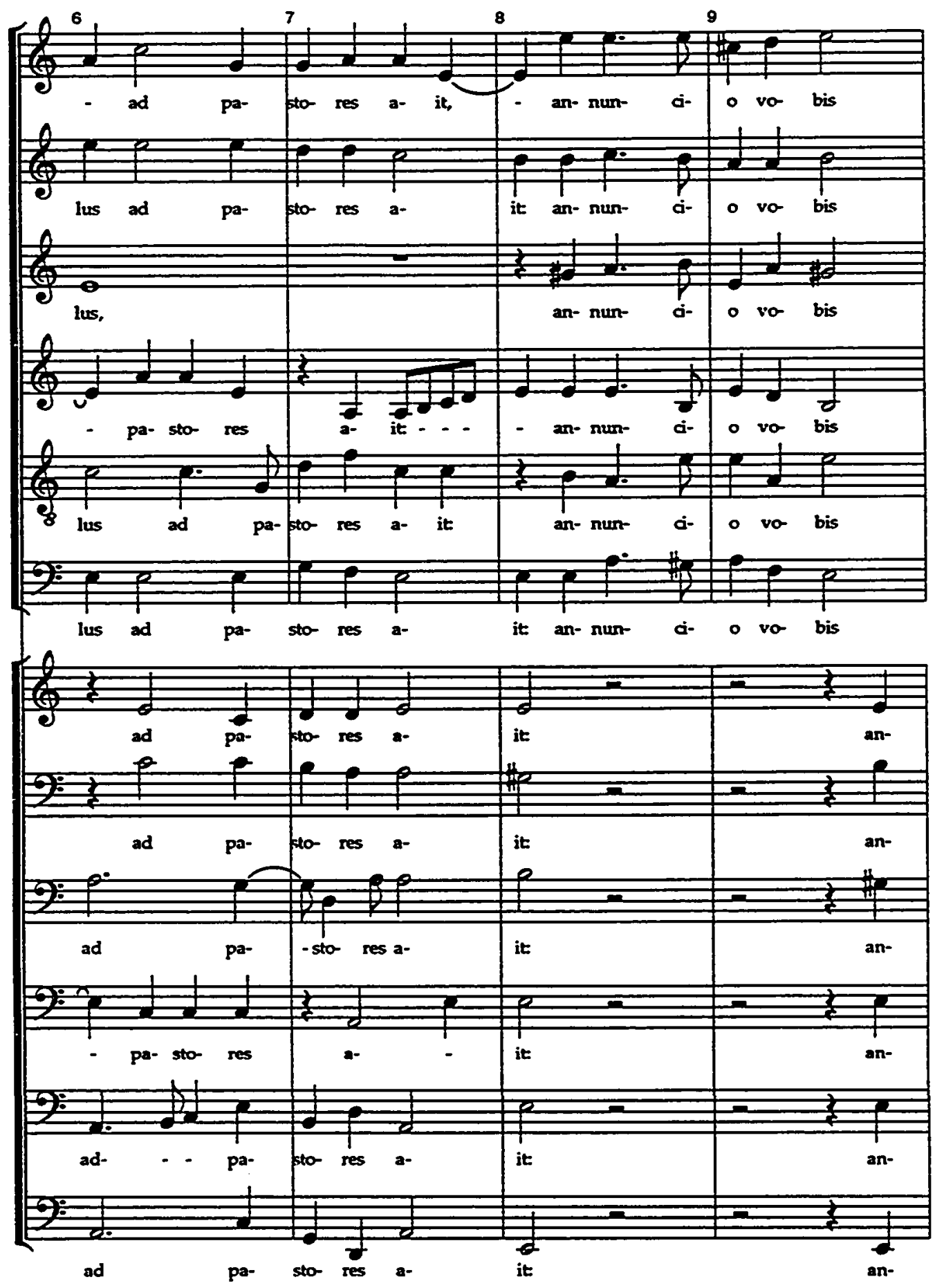




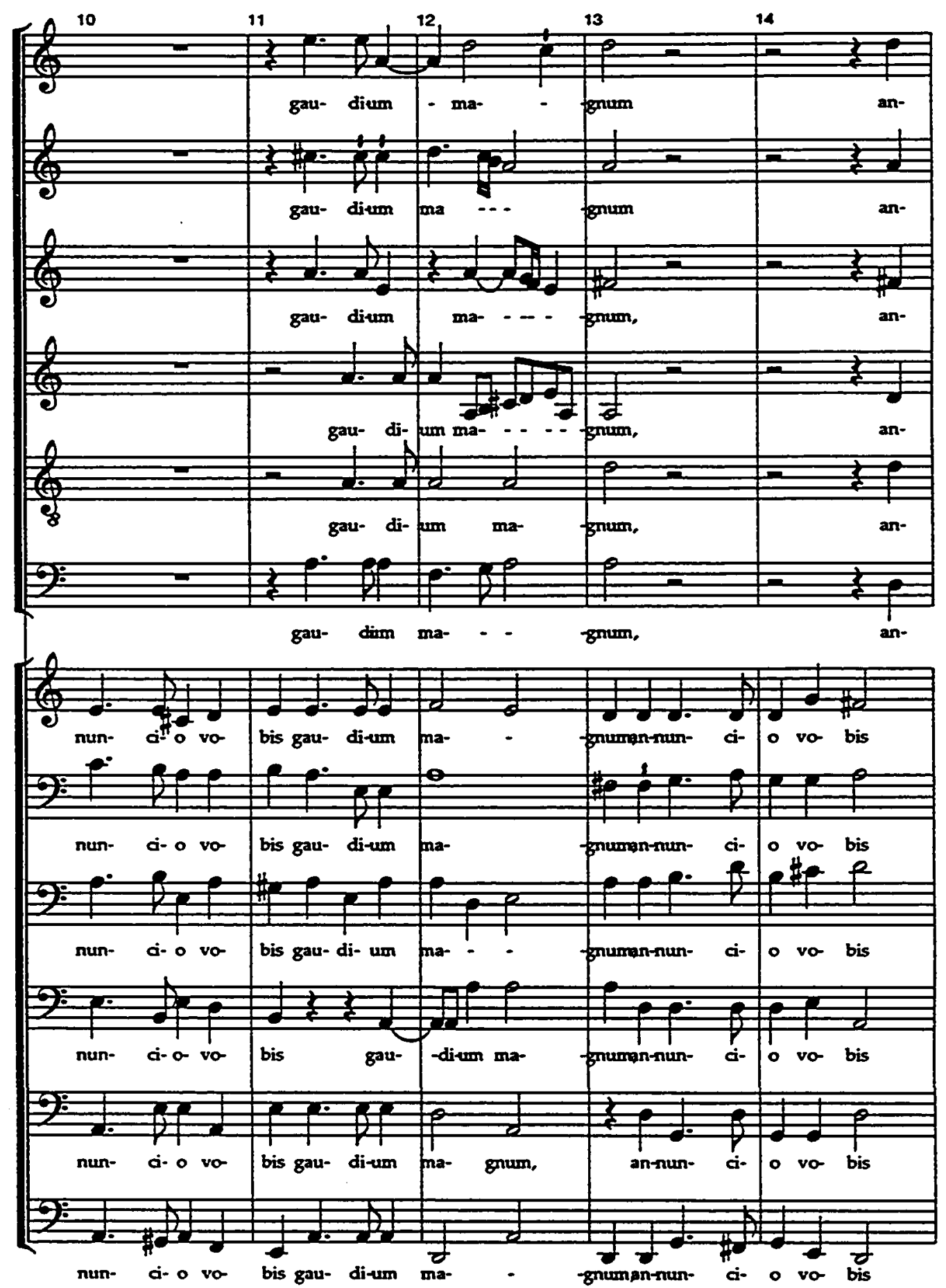




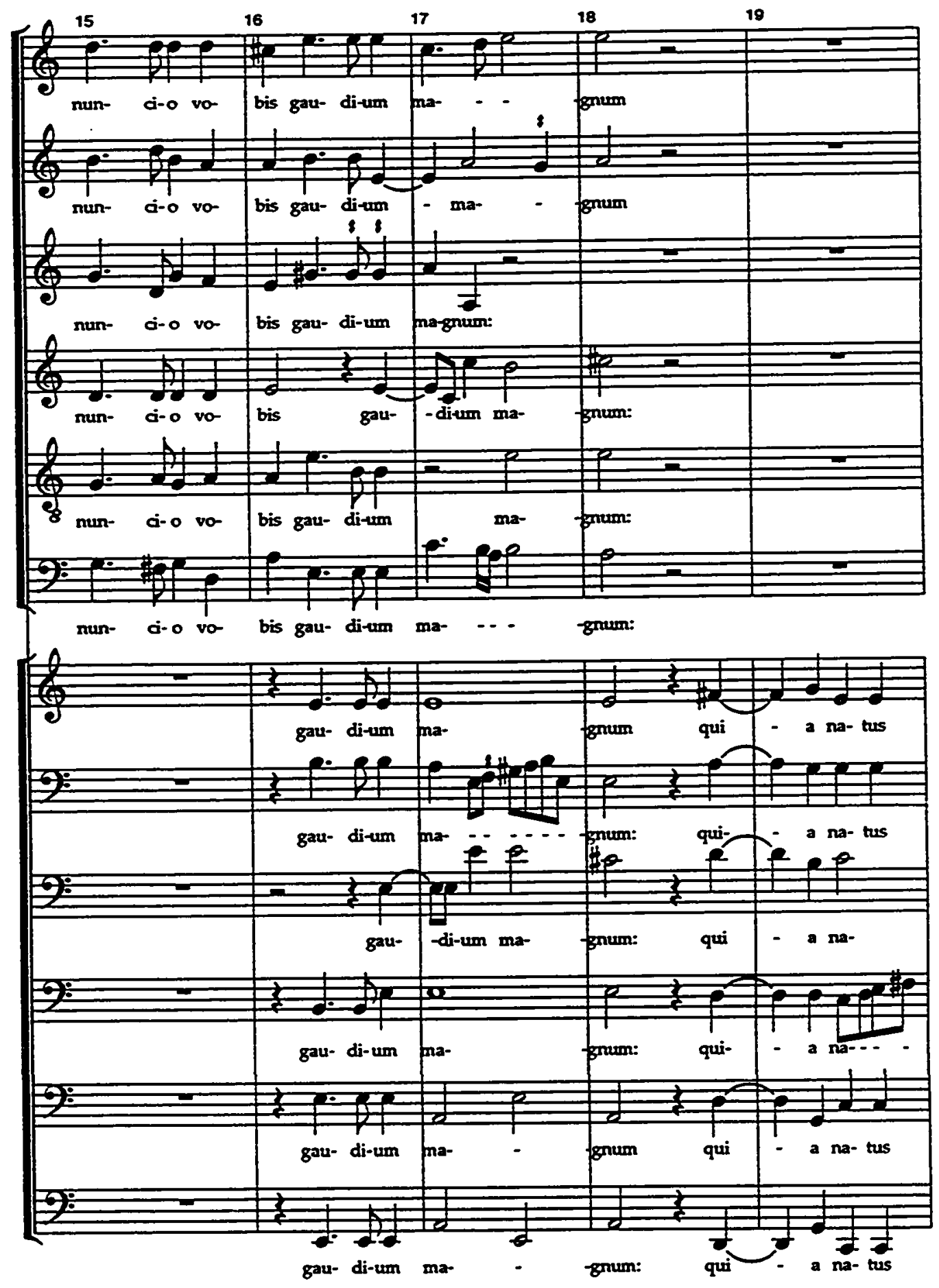




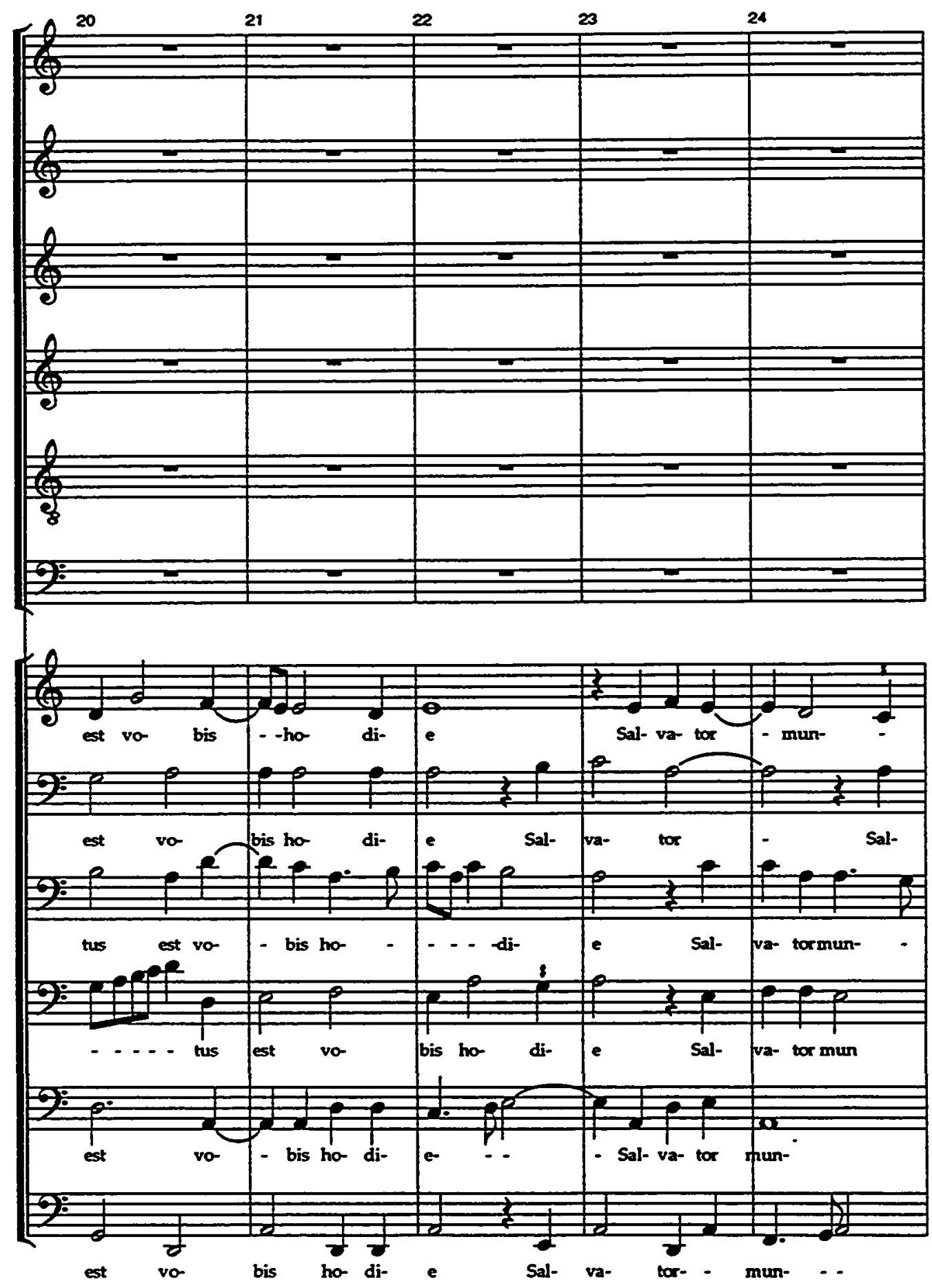




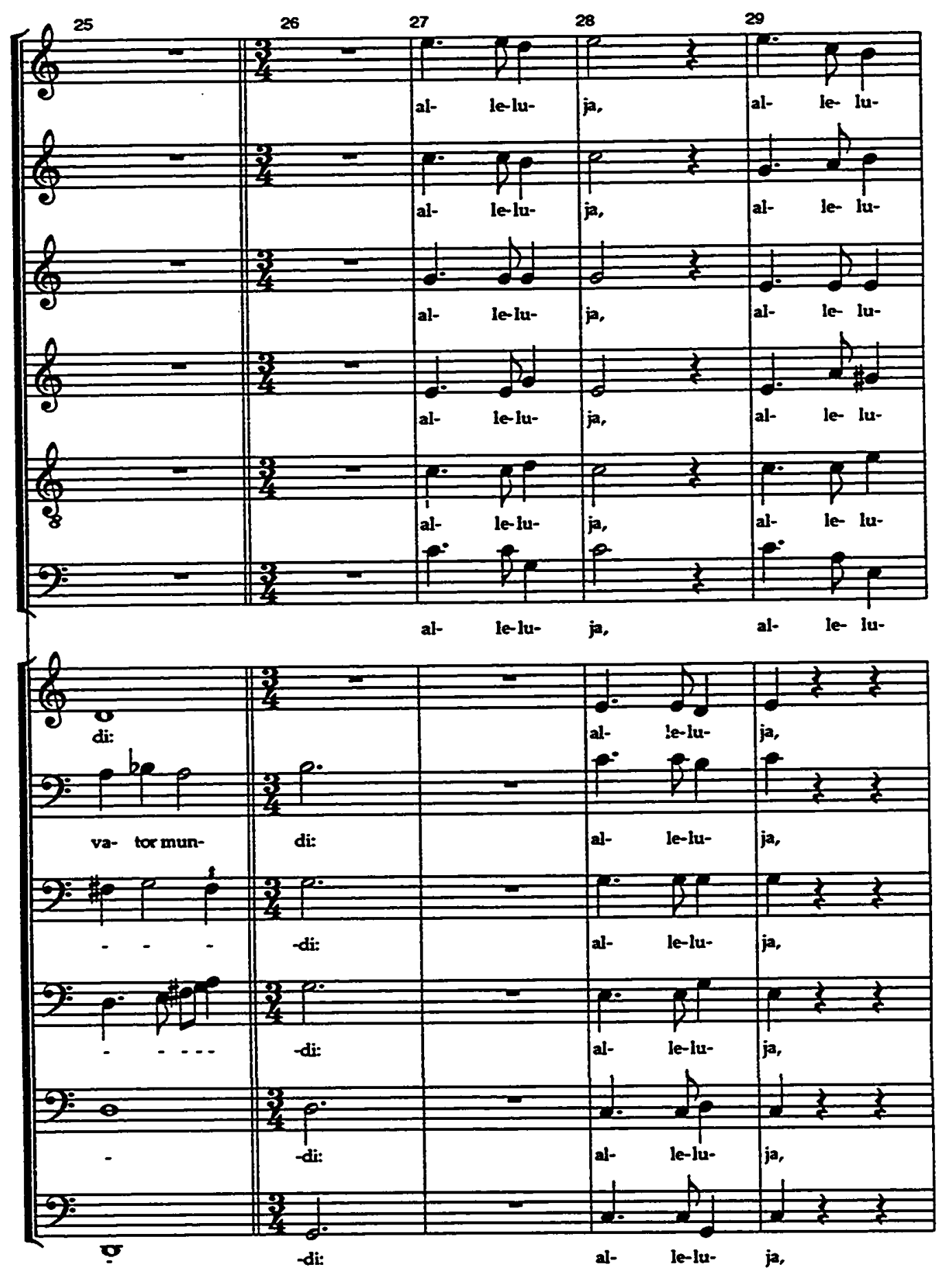




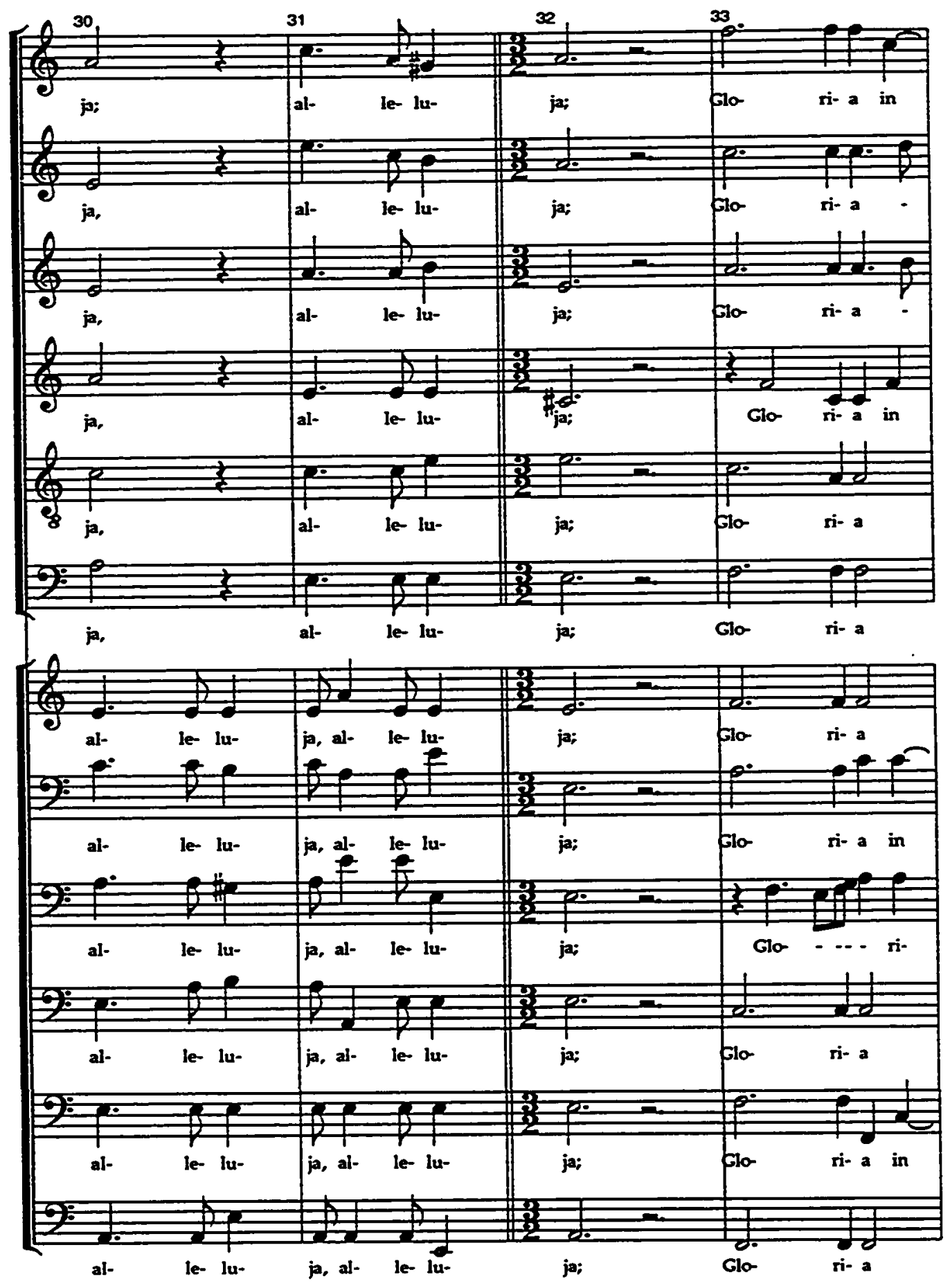




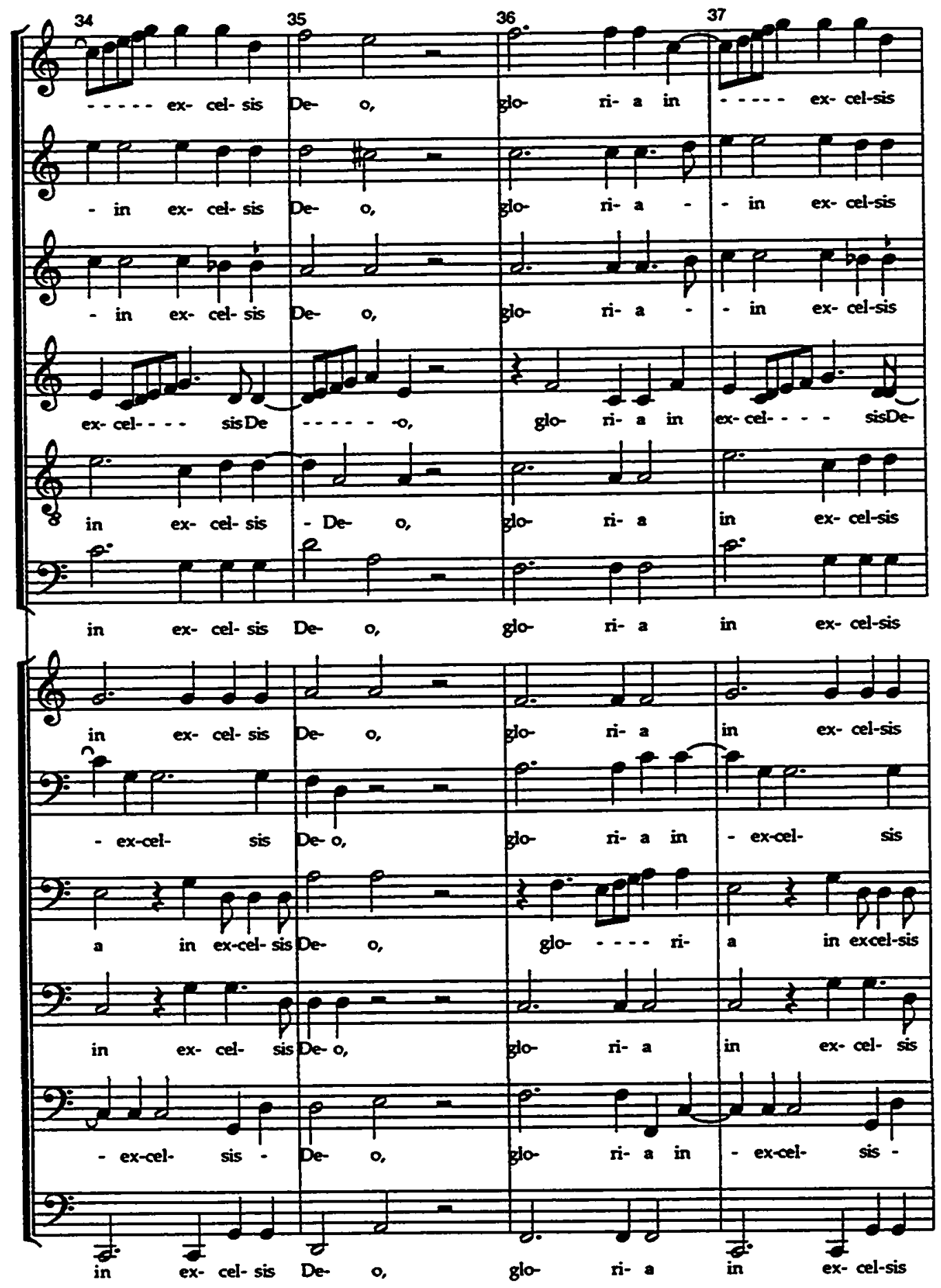




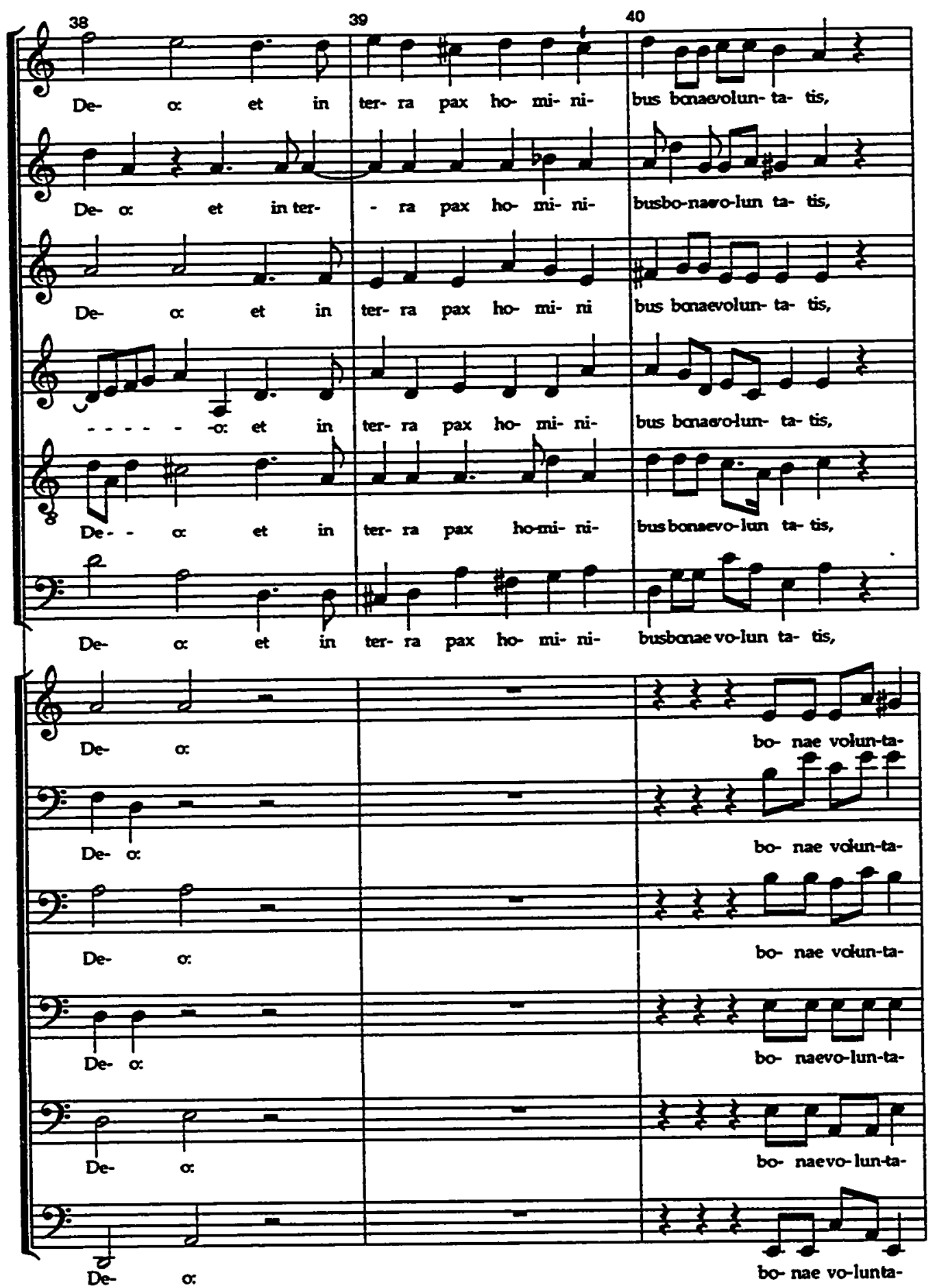




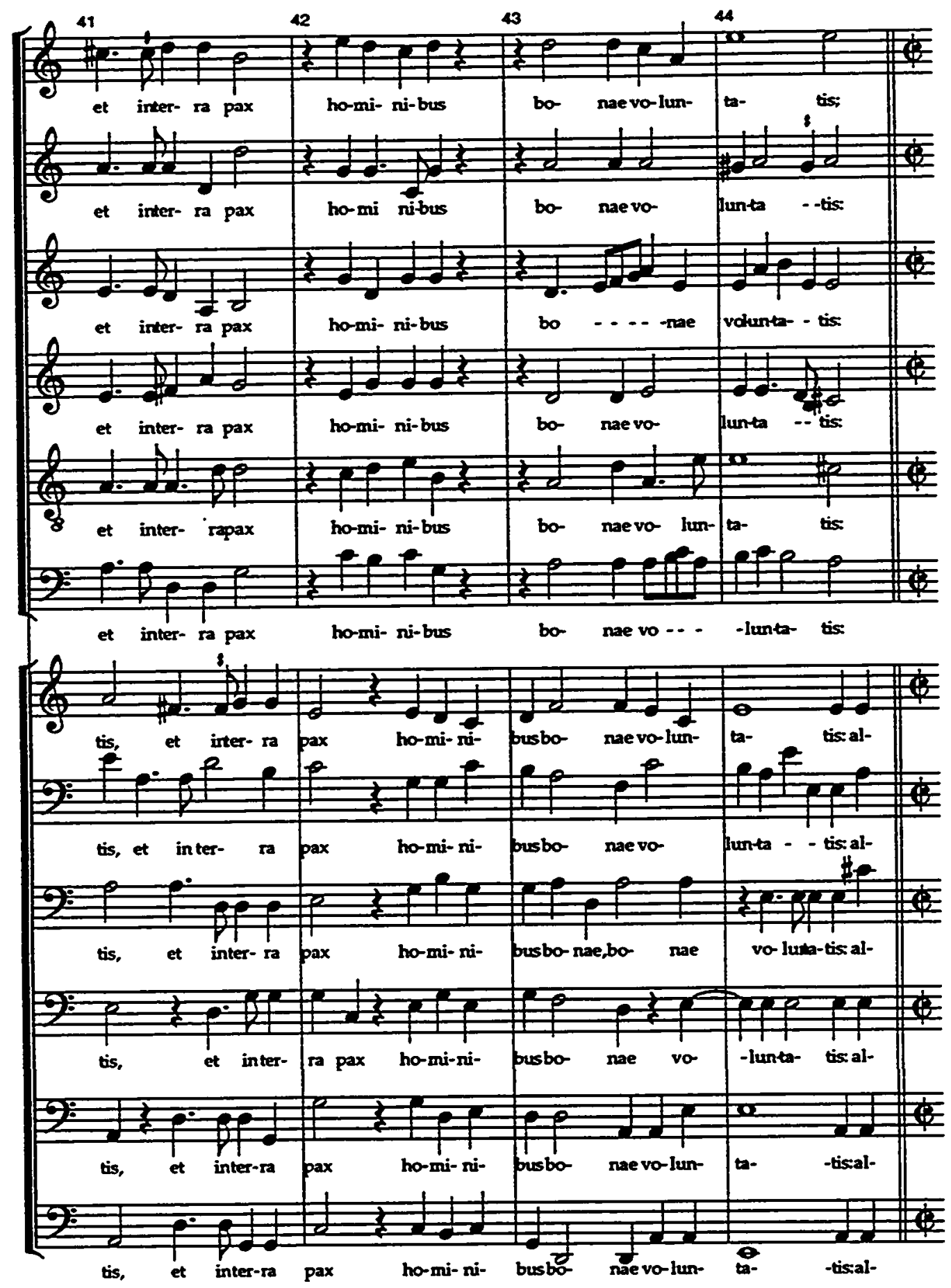




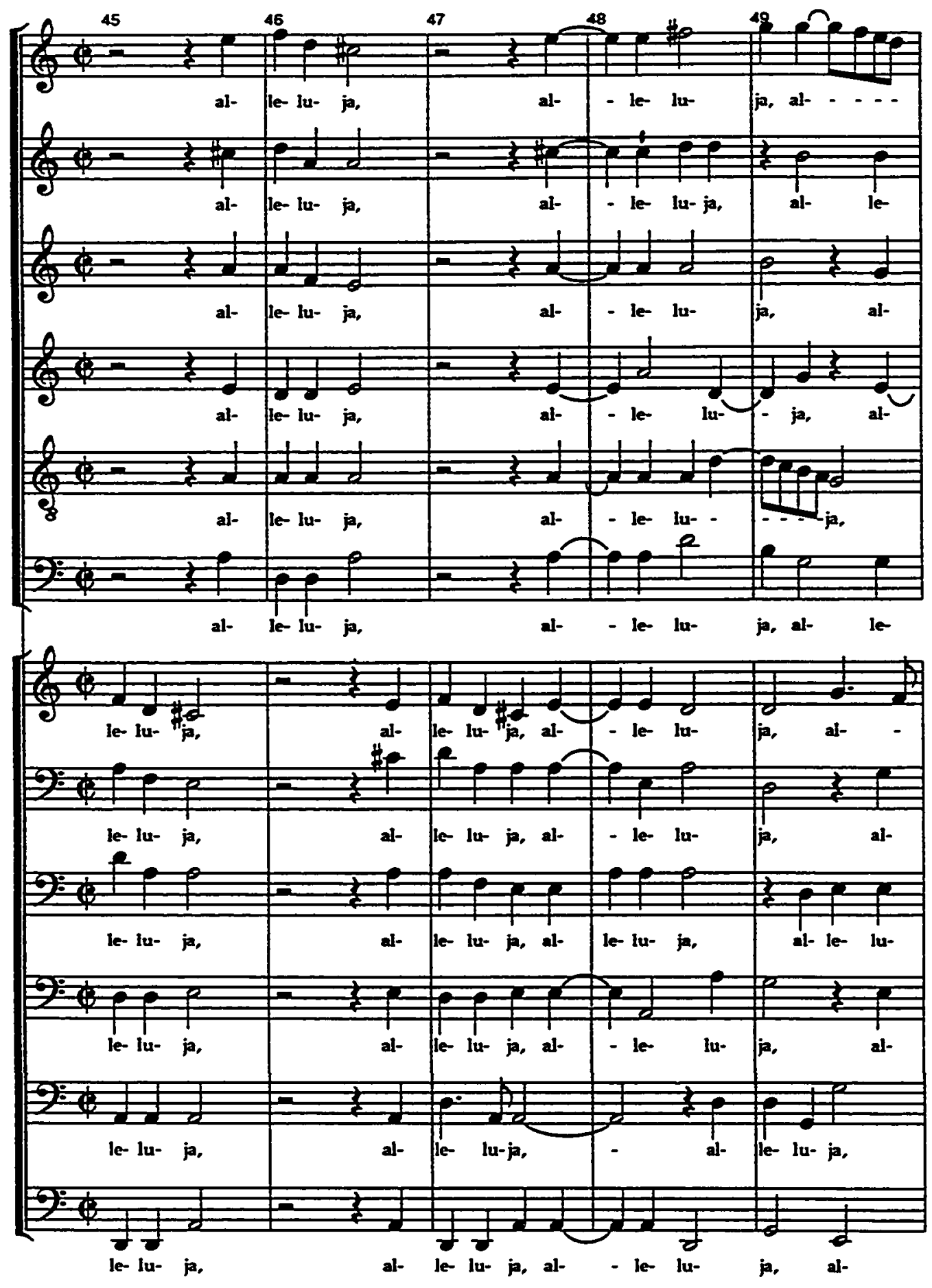




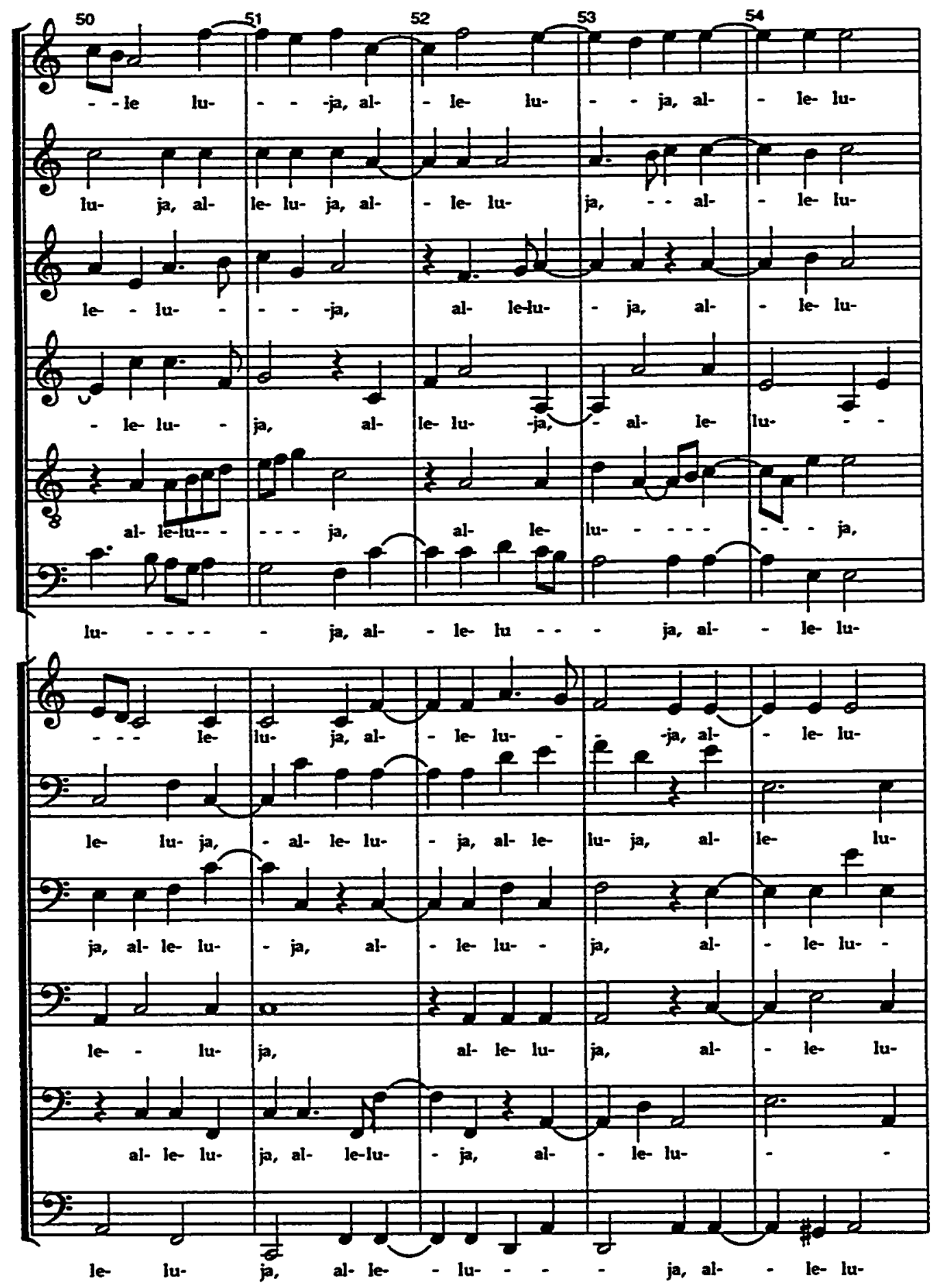




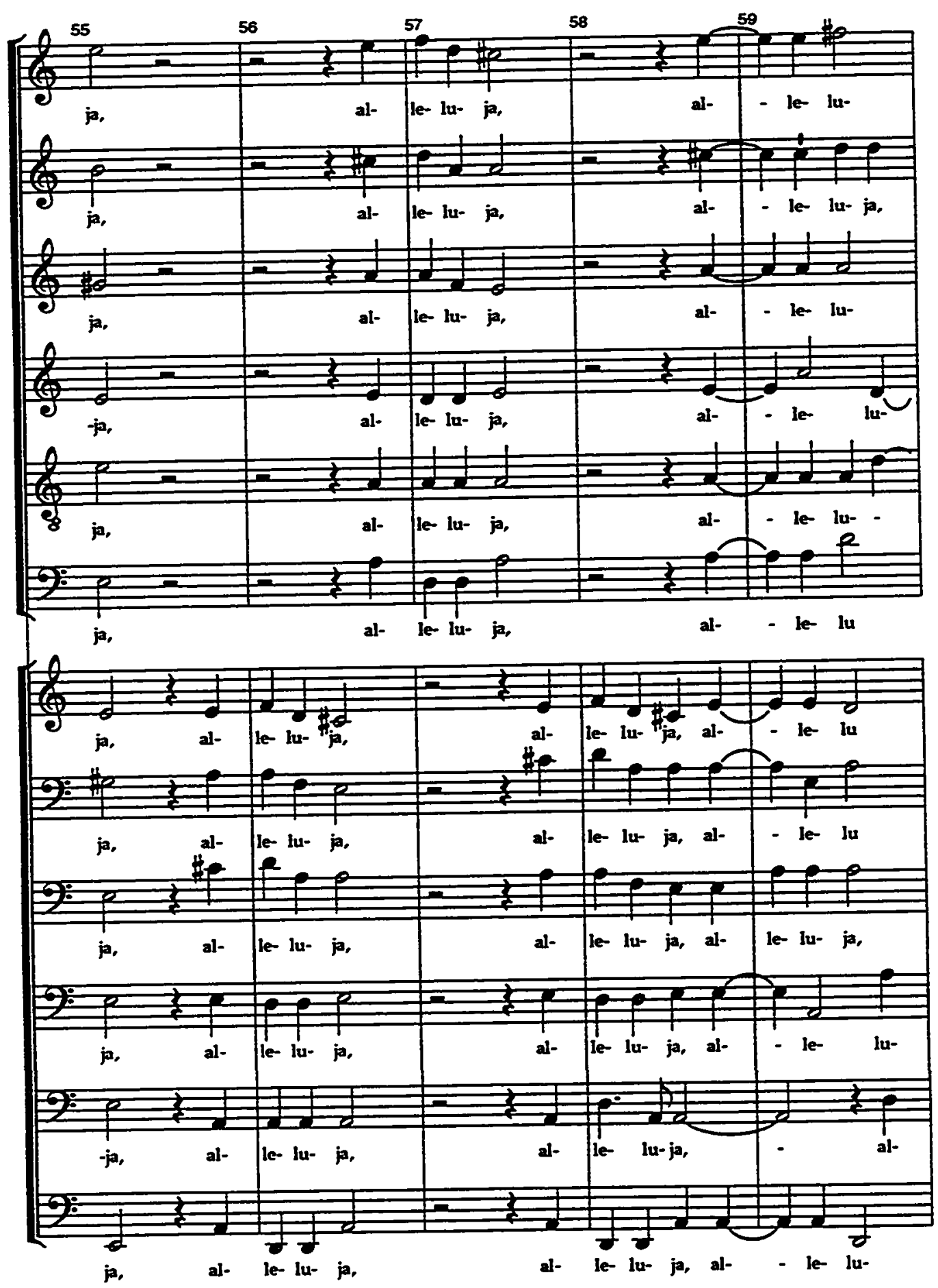




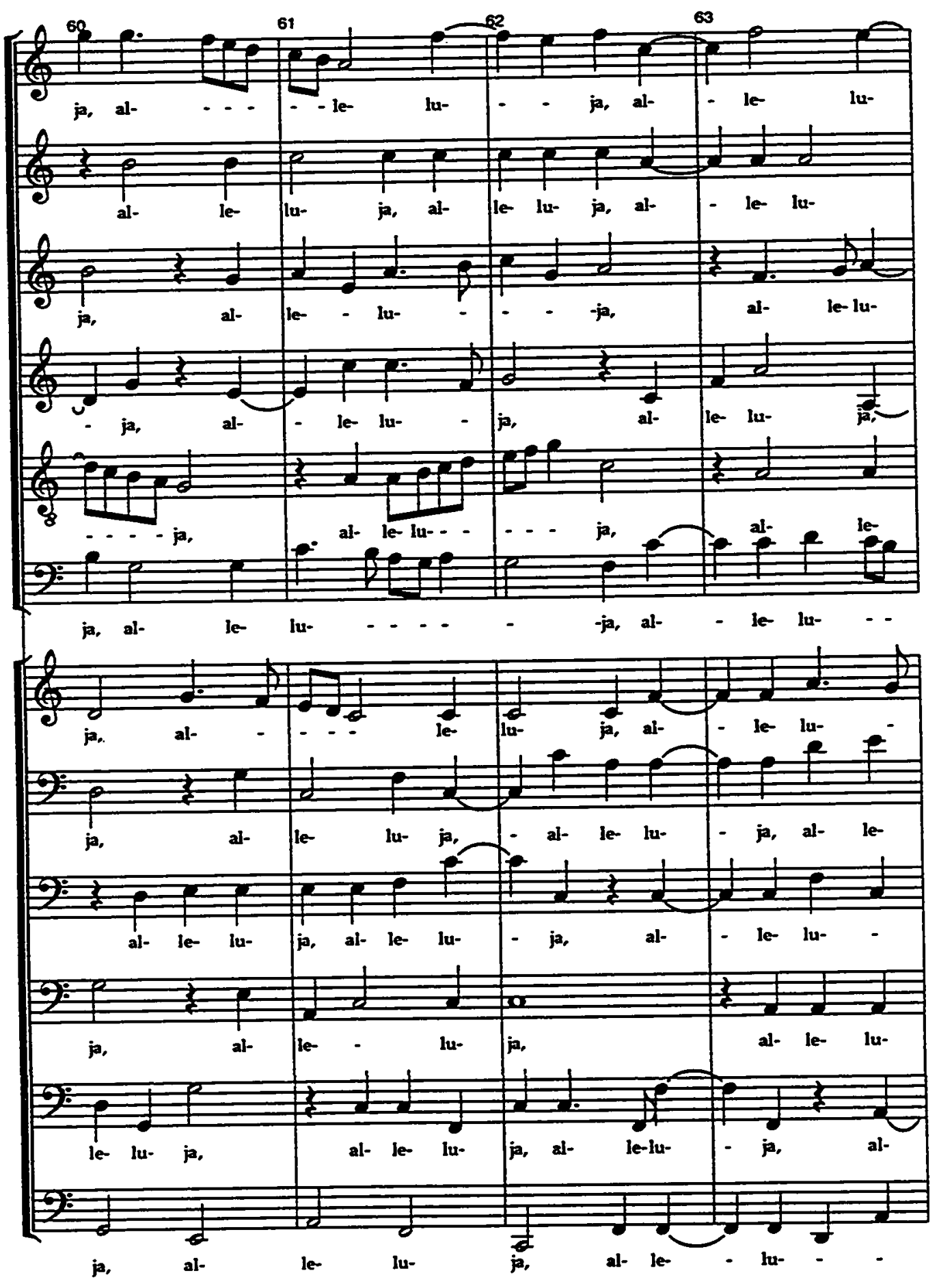




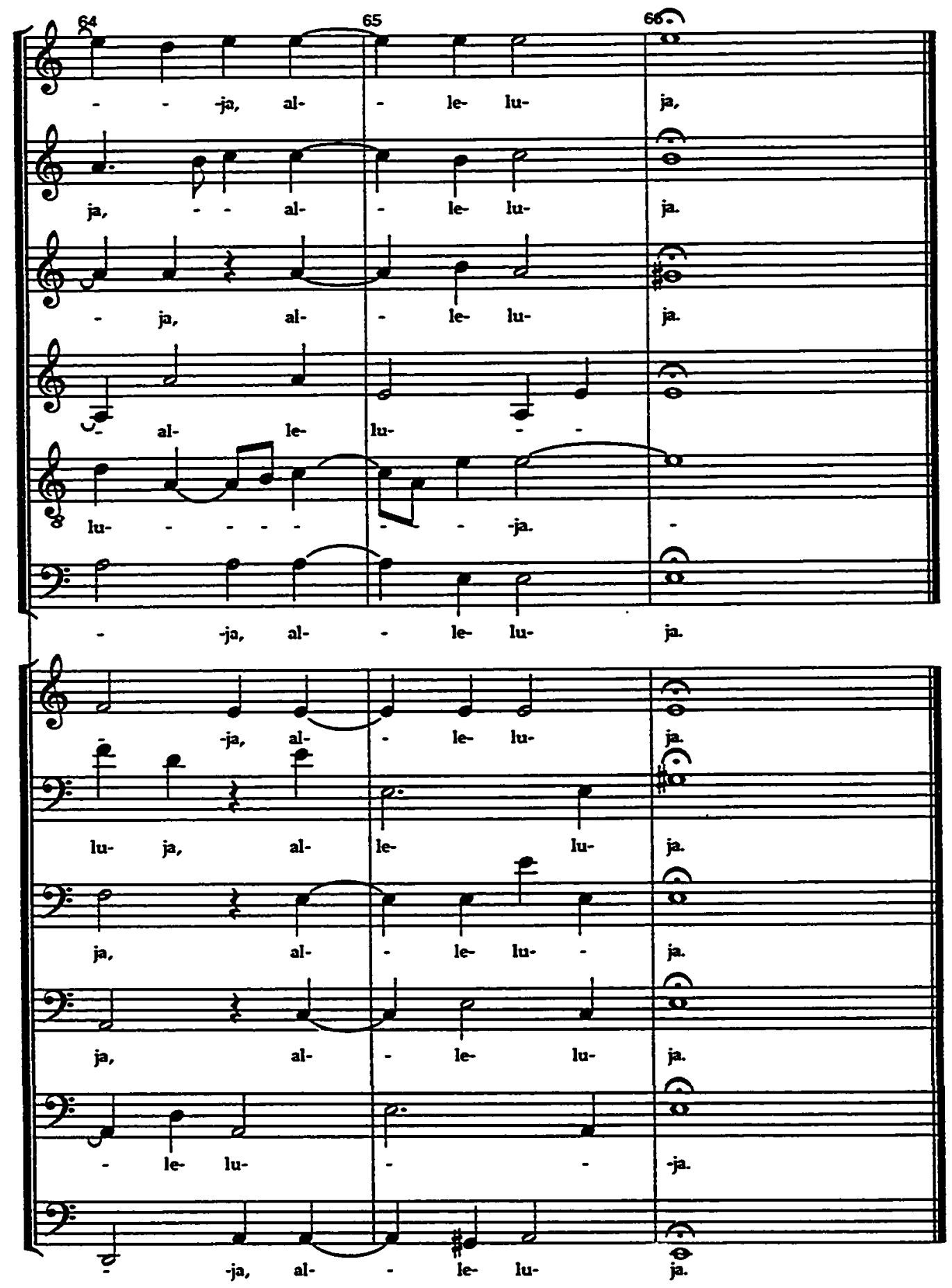



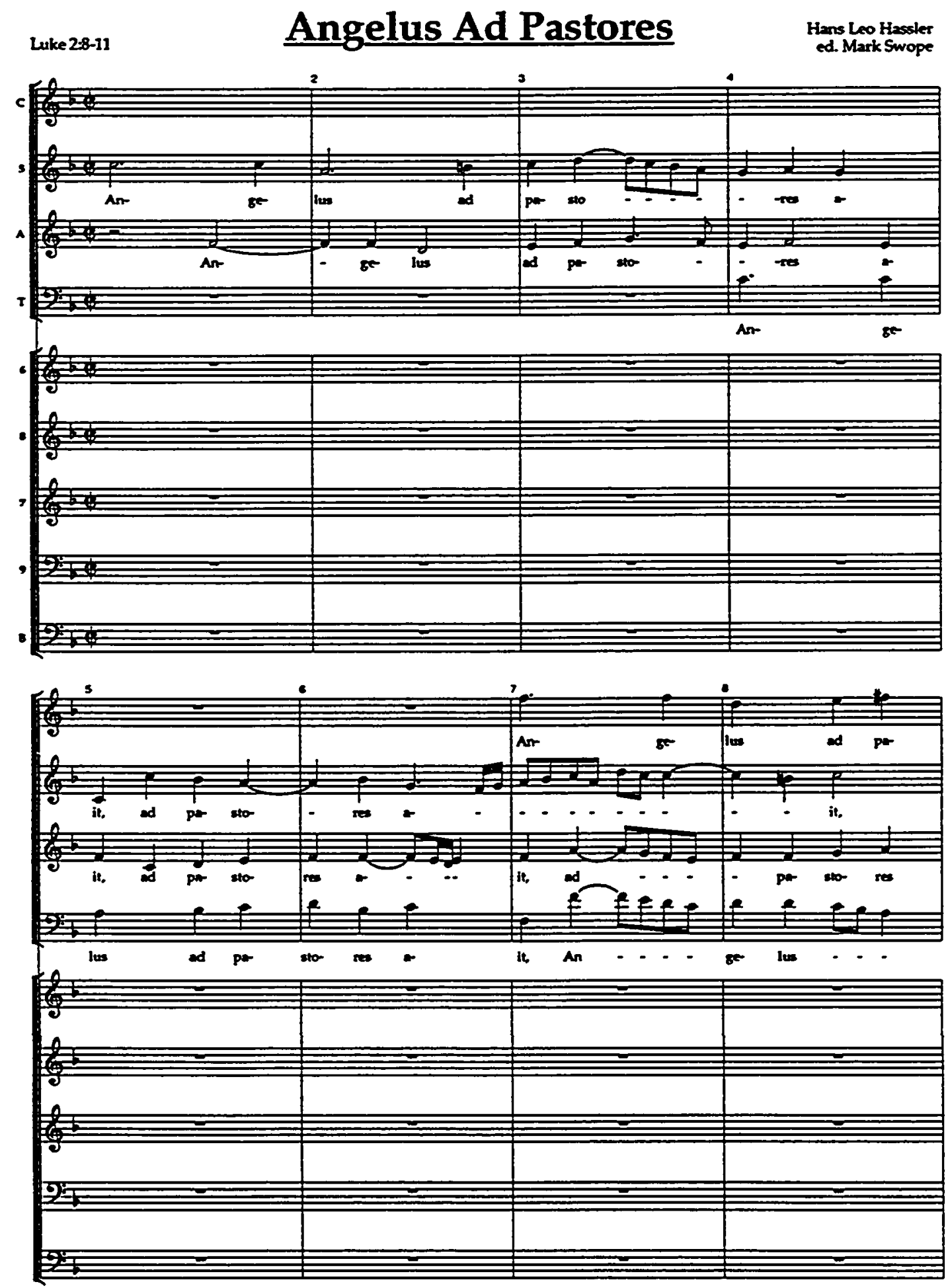

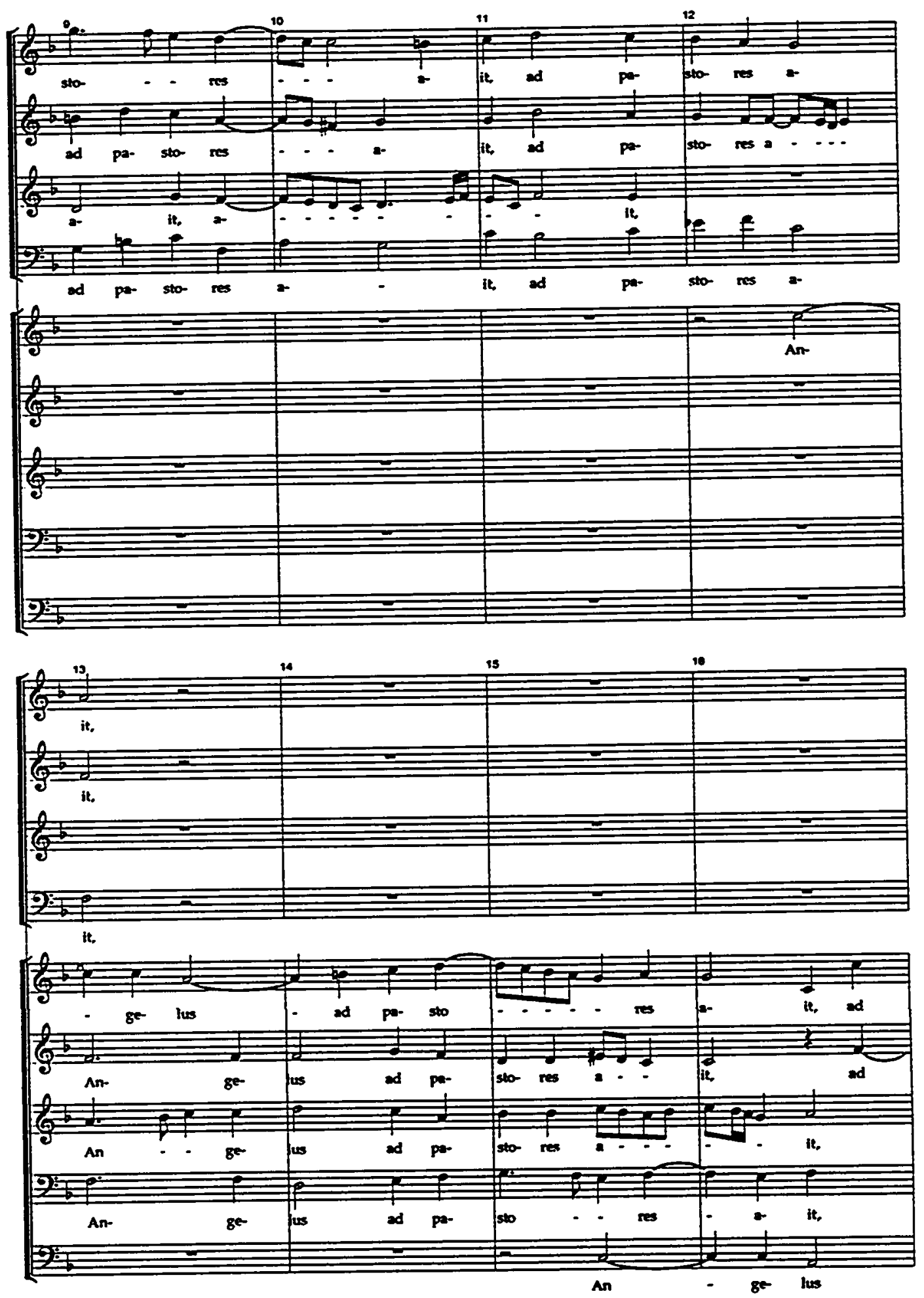


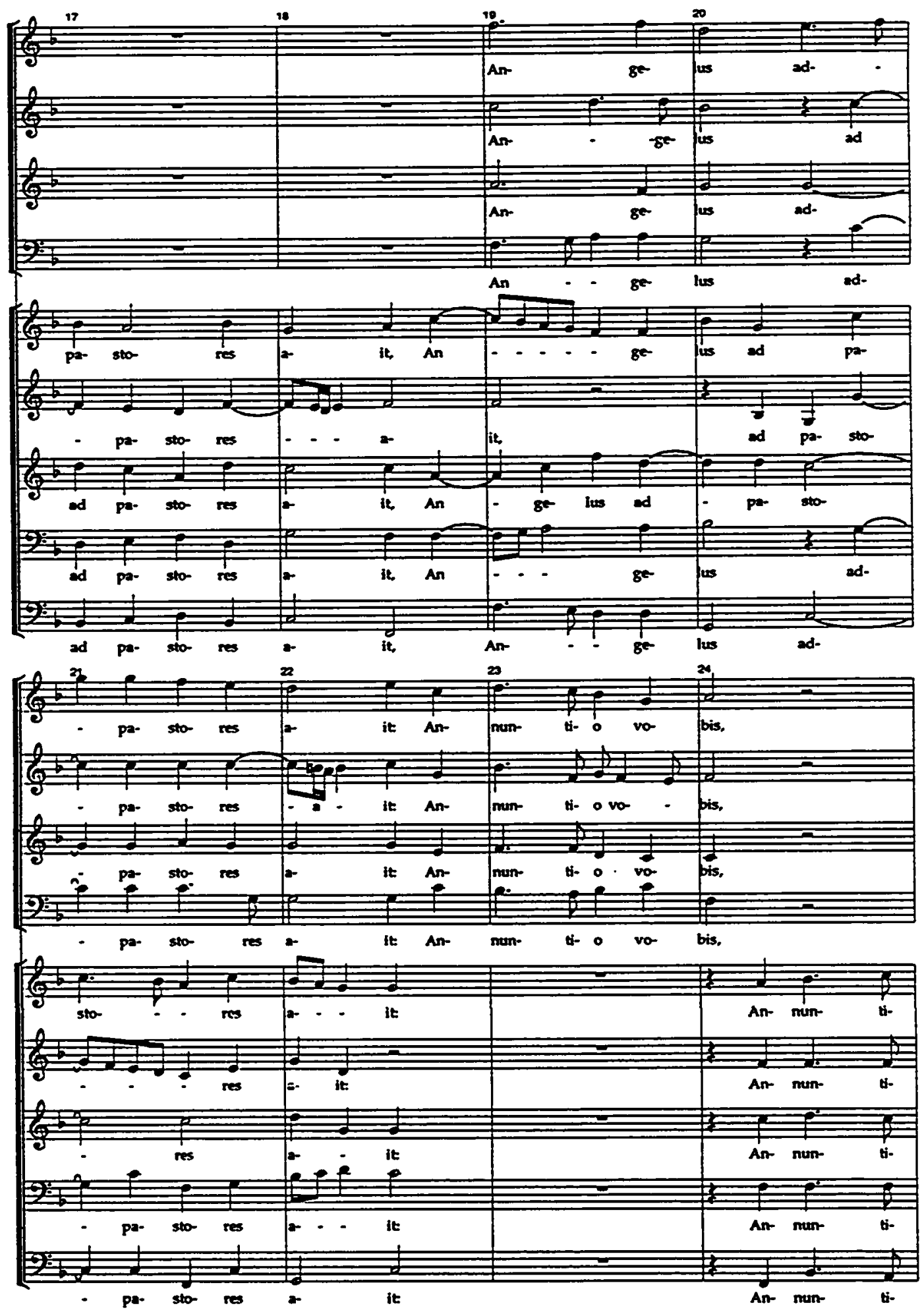




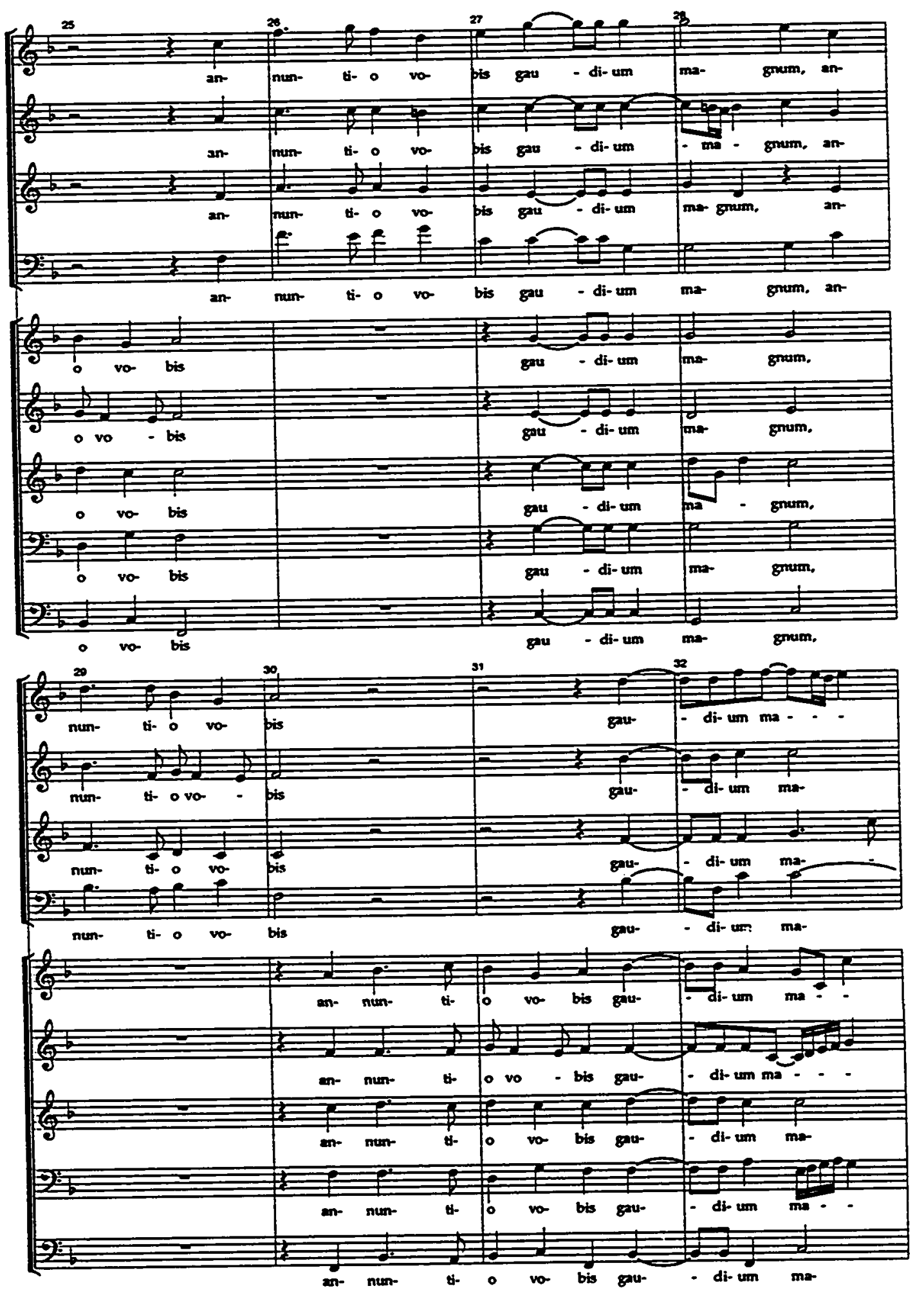



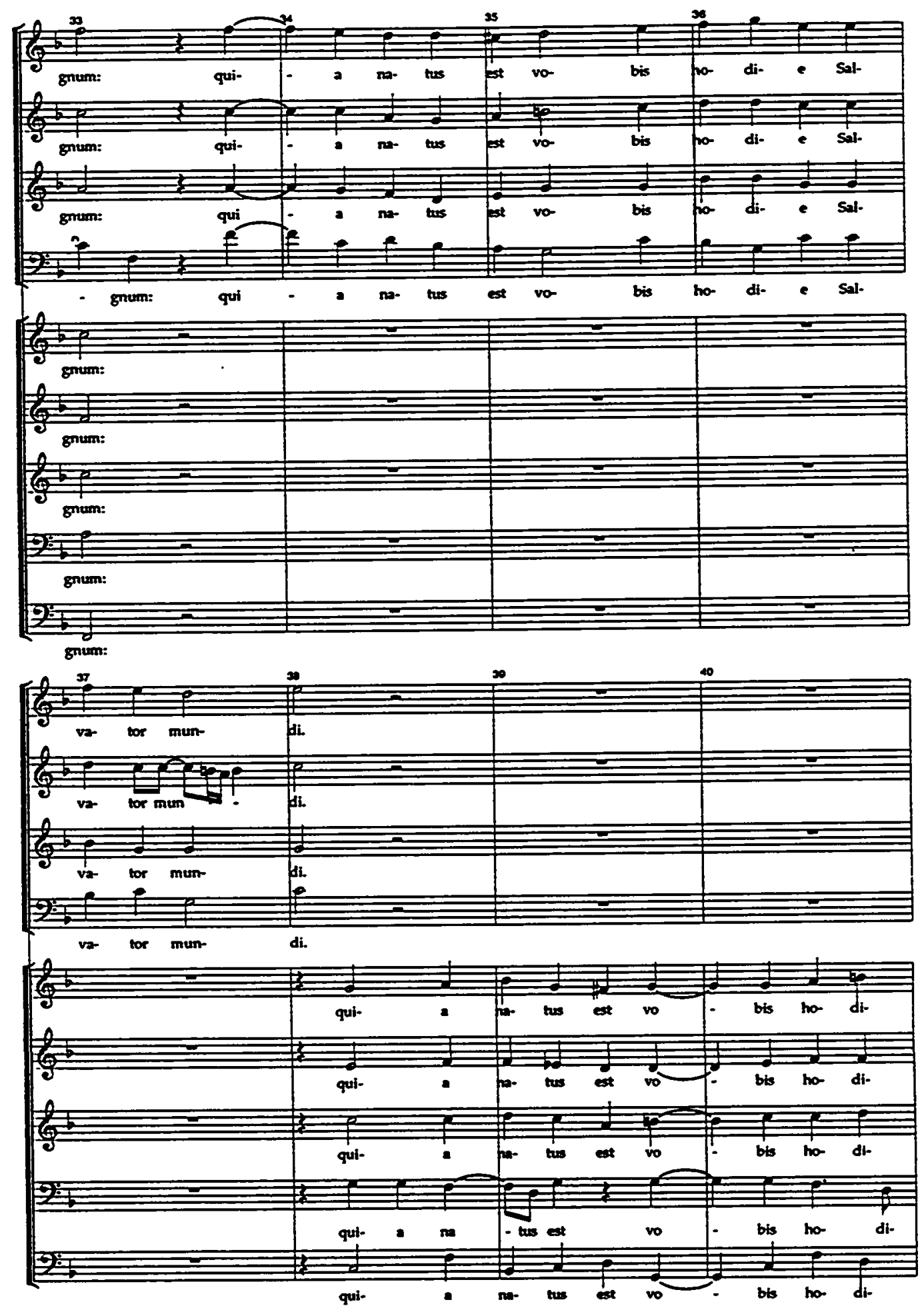


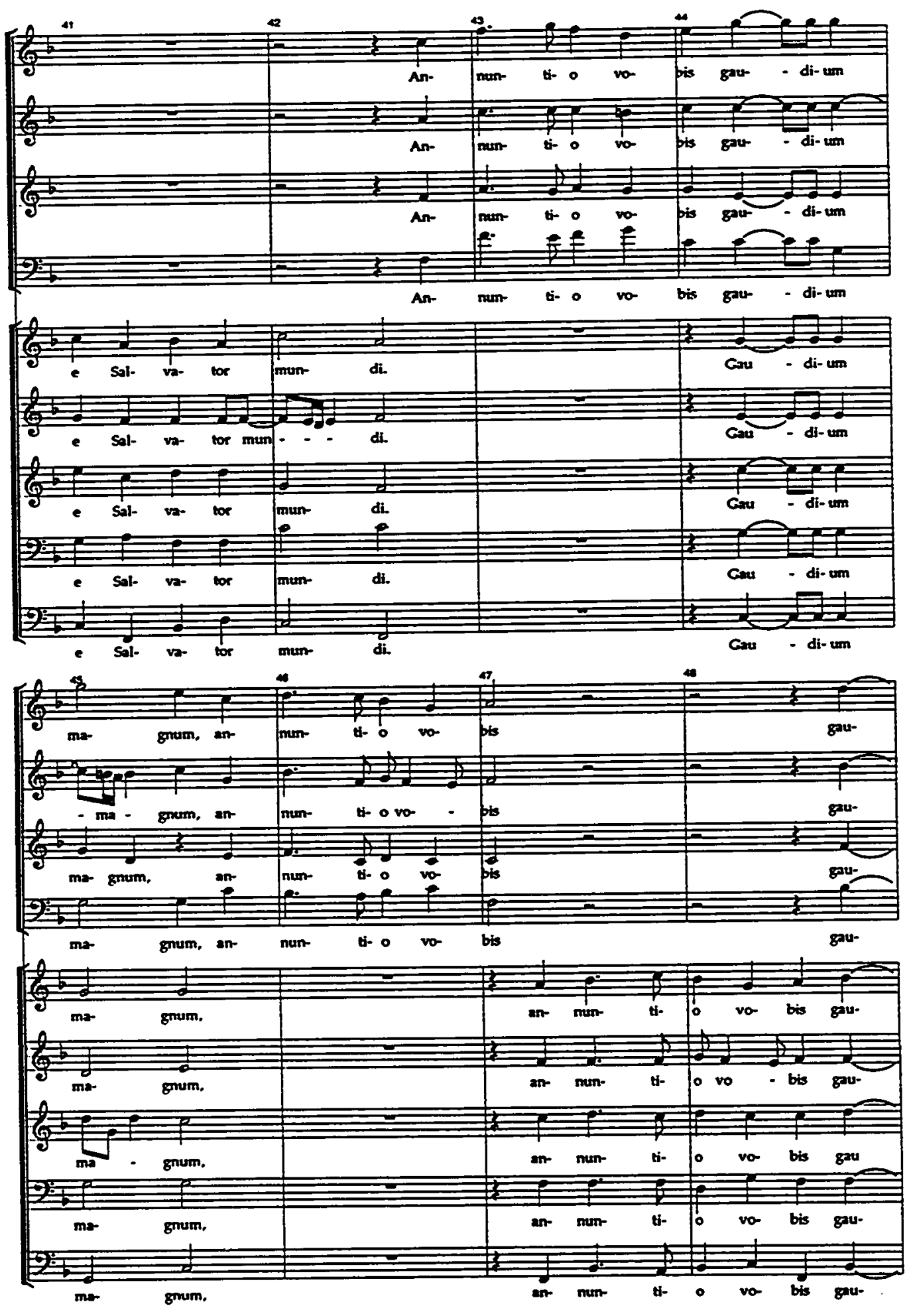



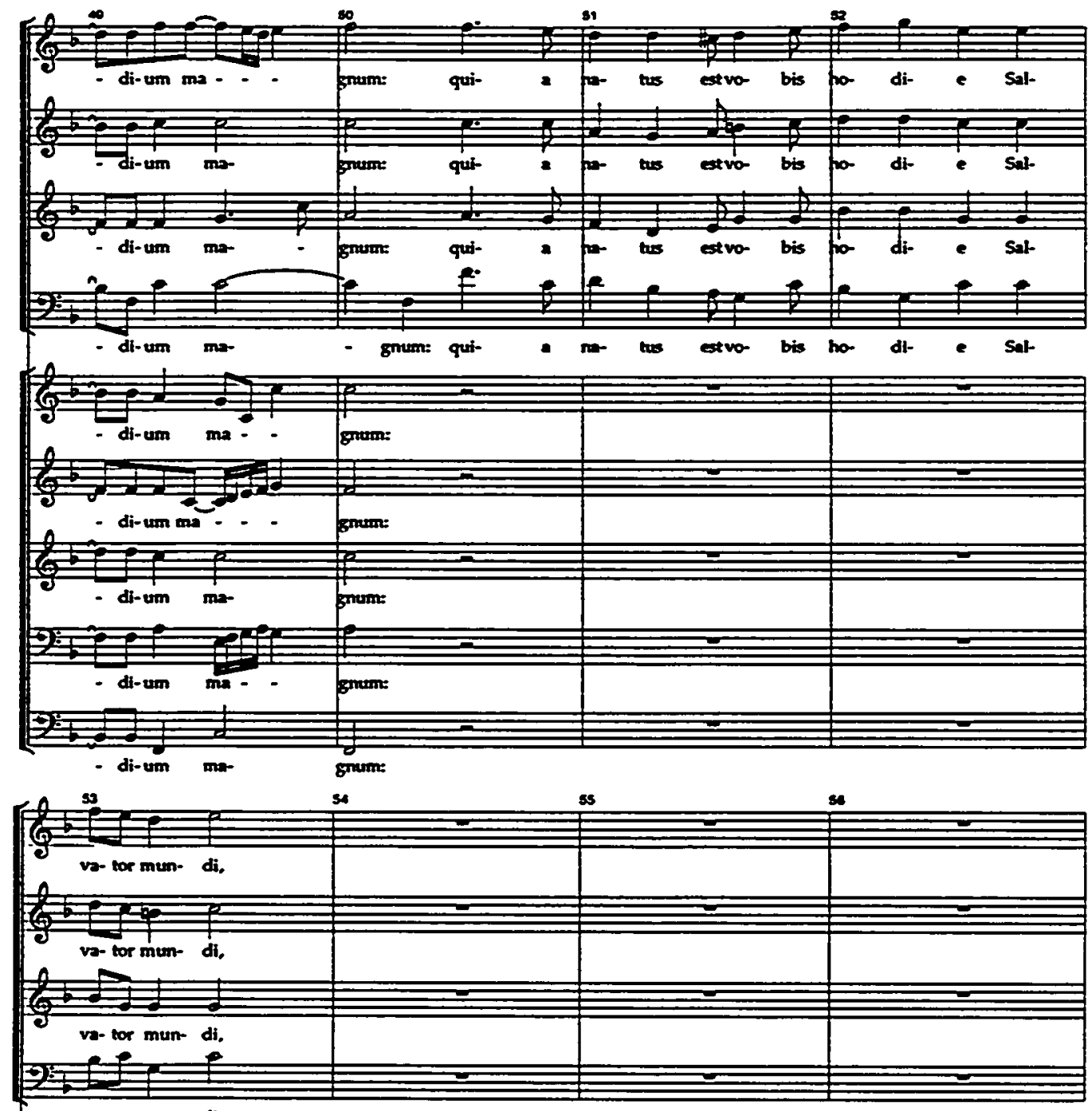

ve- tor mun- di,

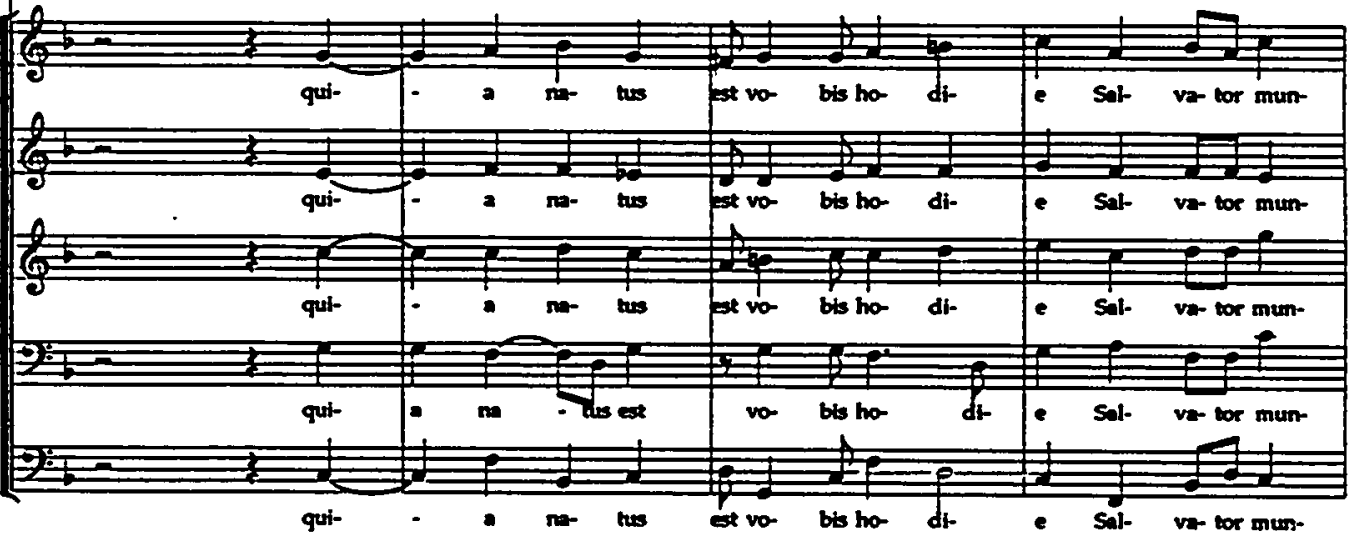




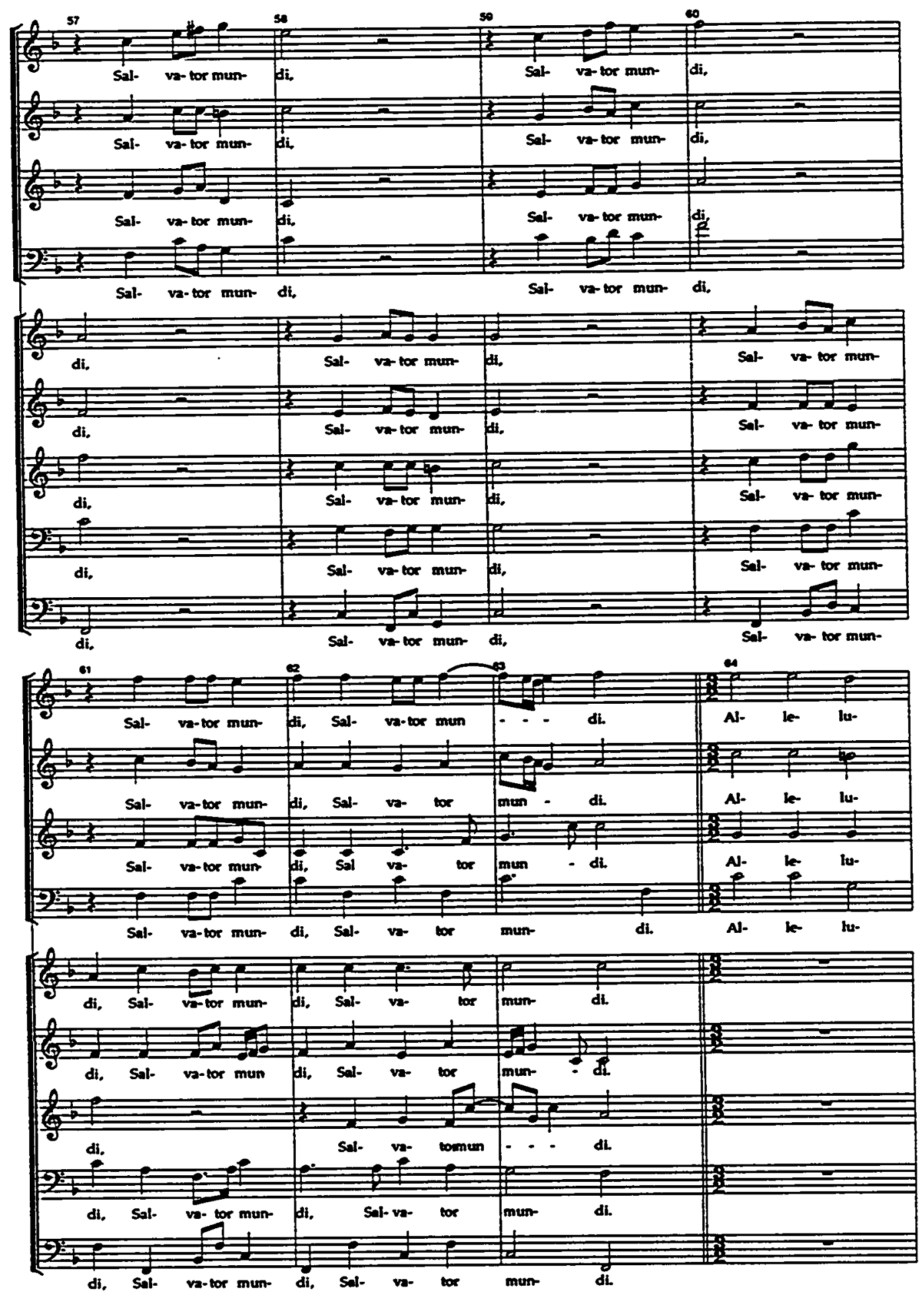



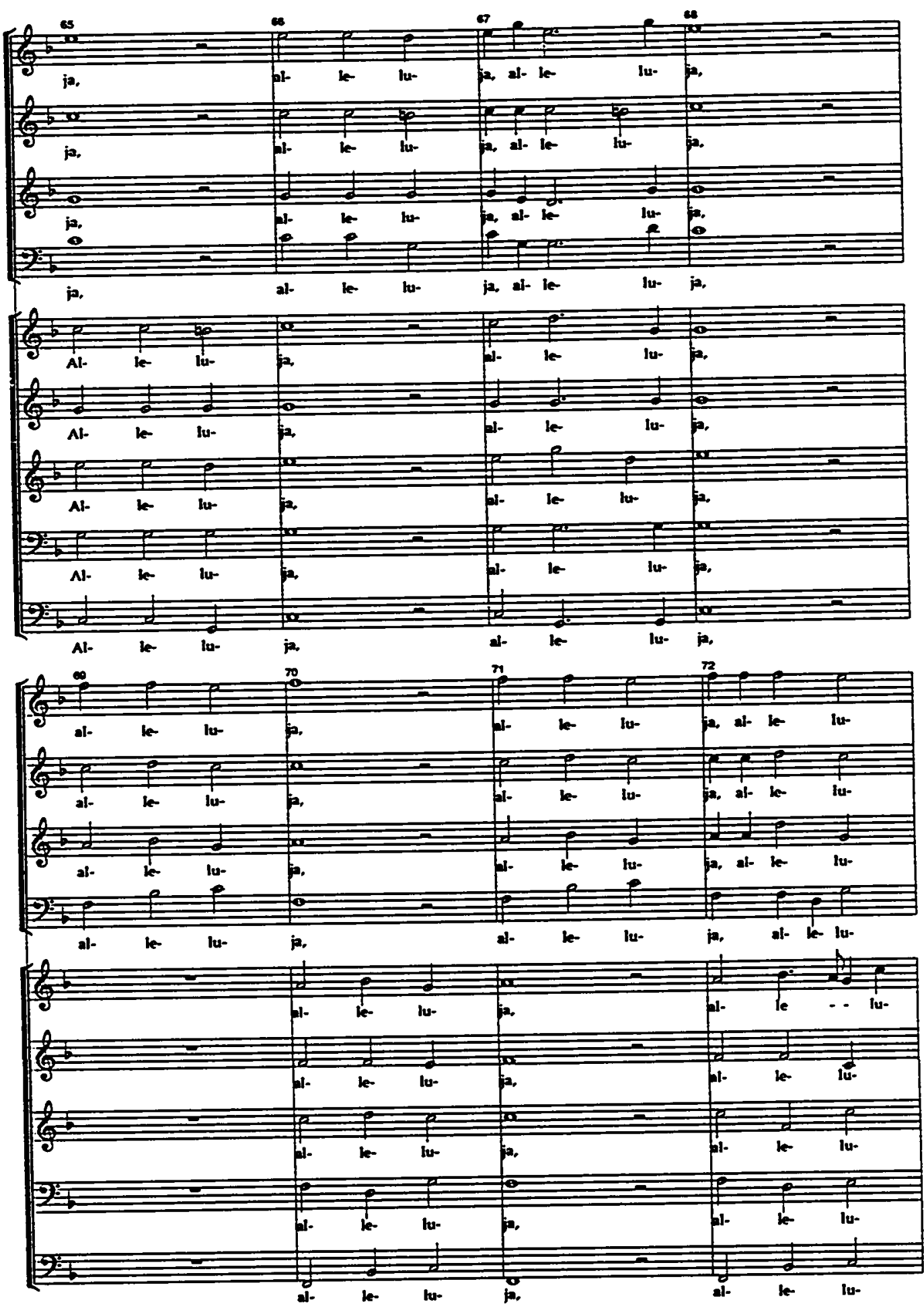


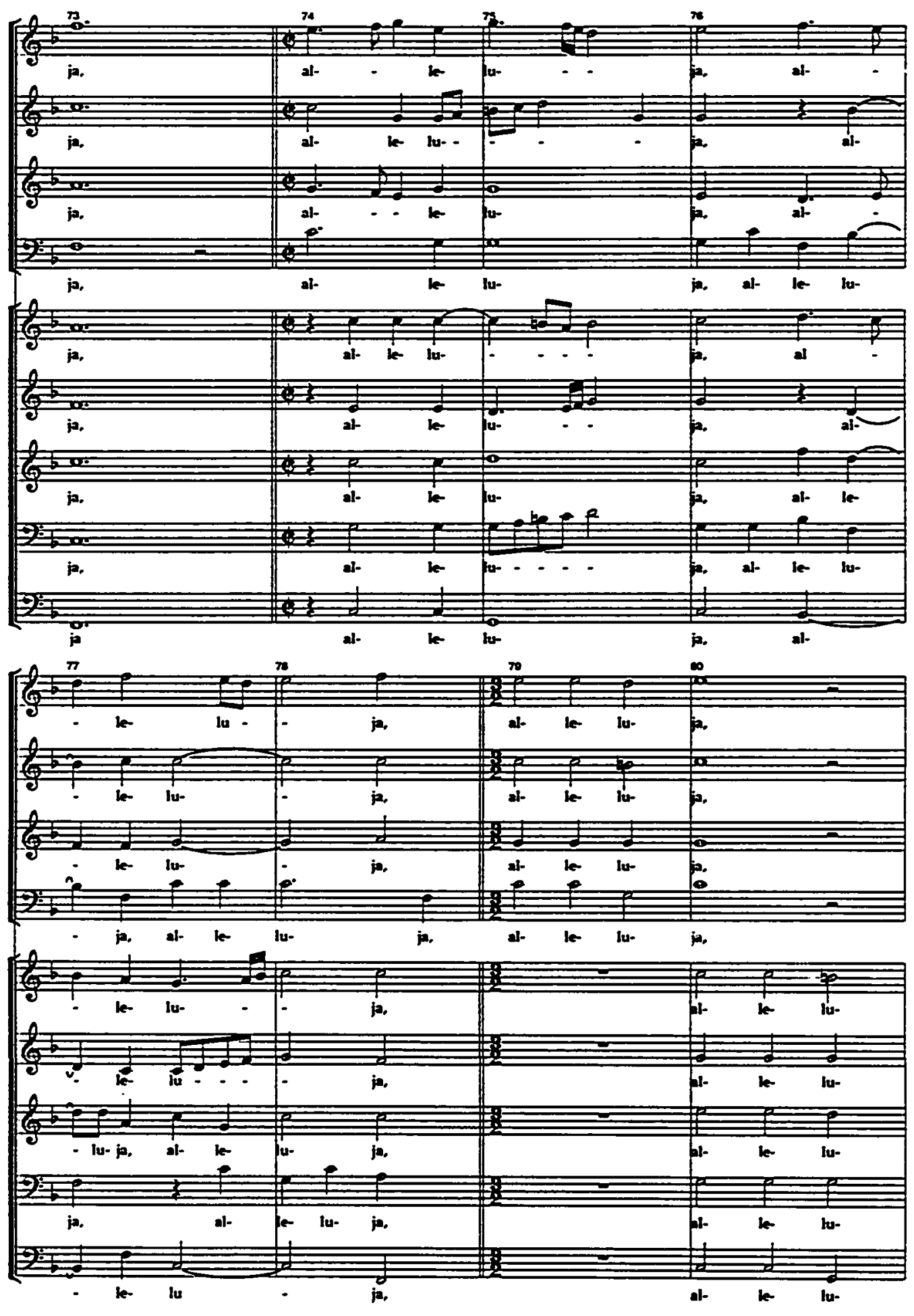




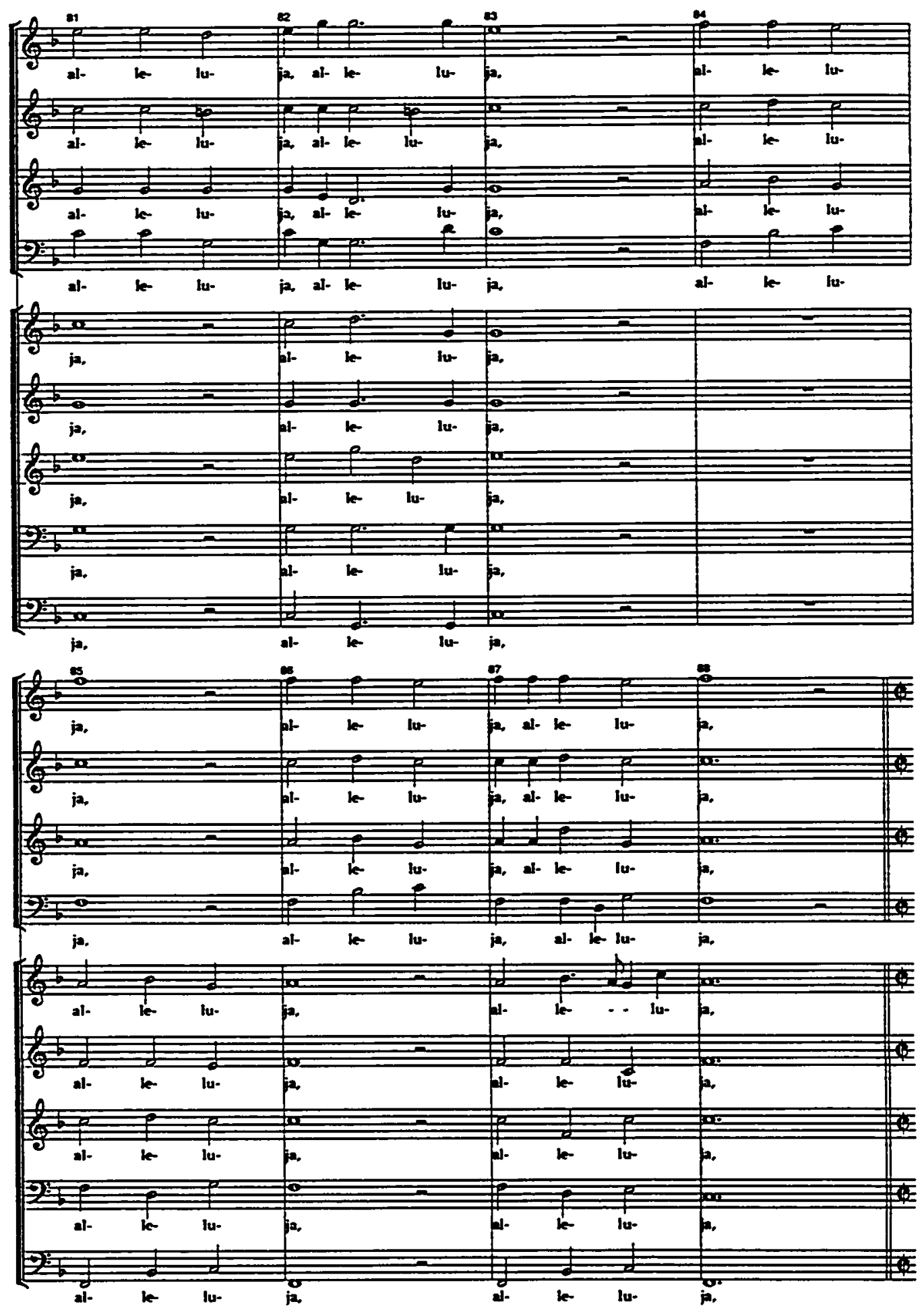



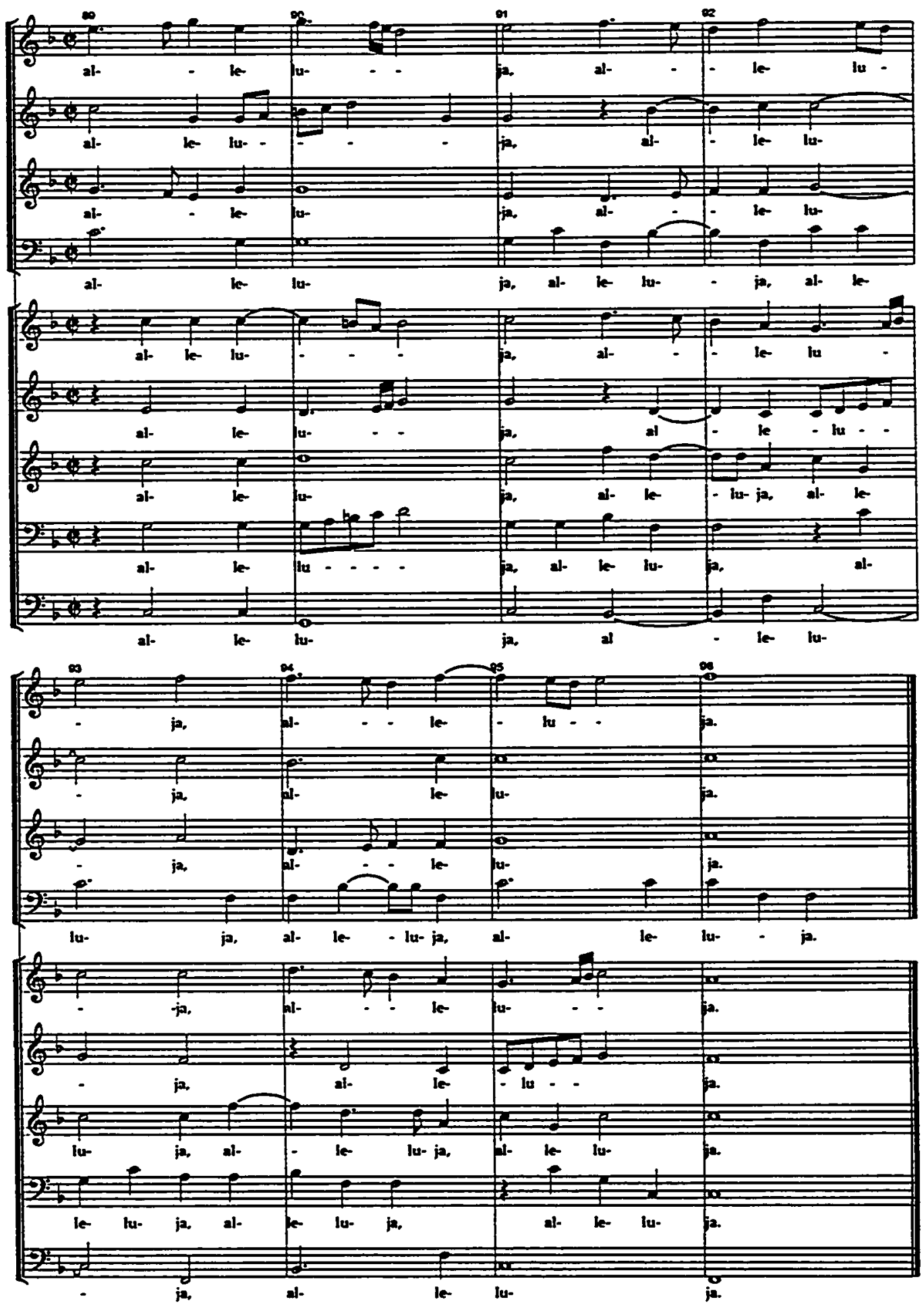


\section{Beati Omnes}
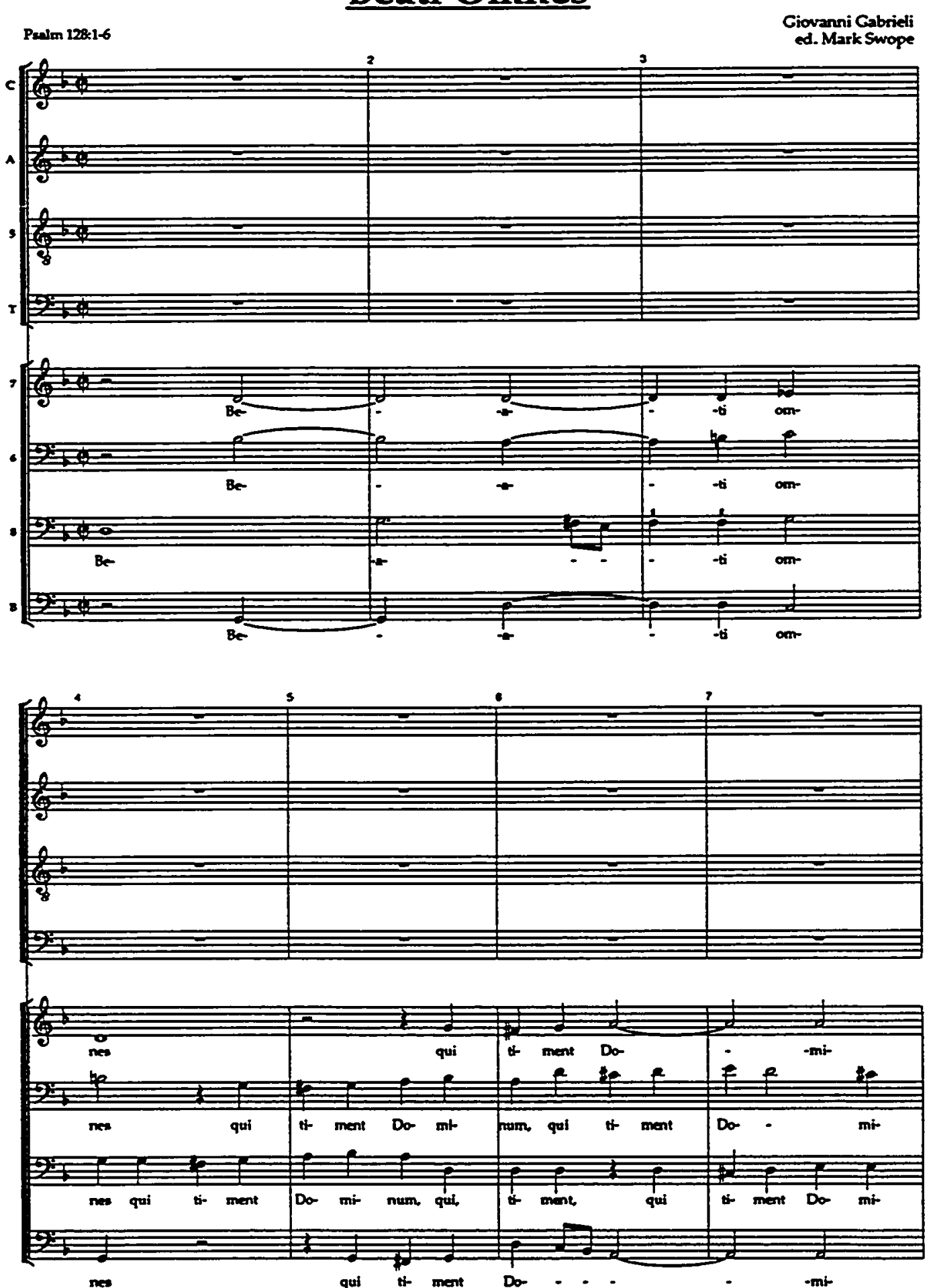

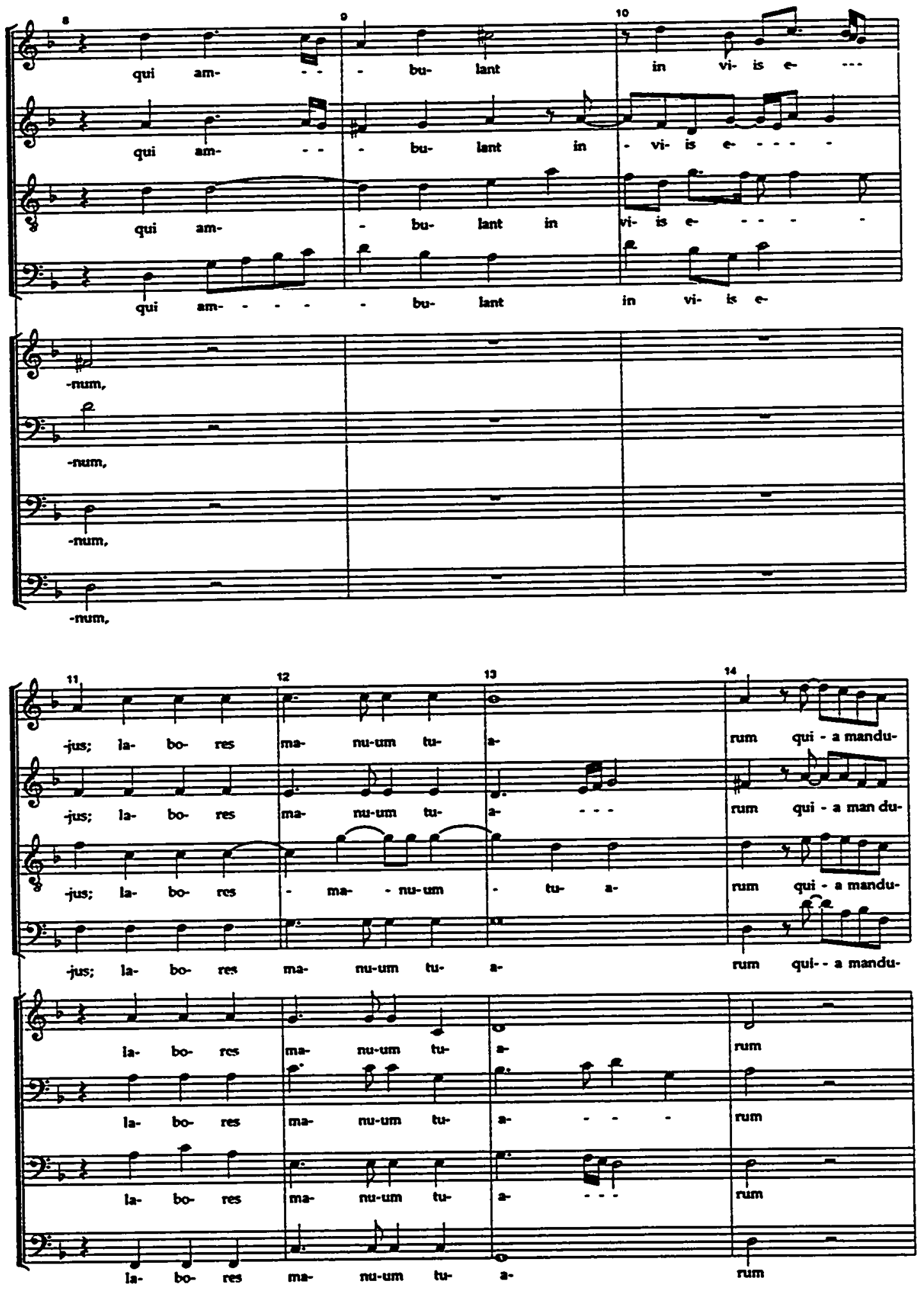

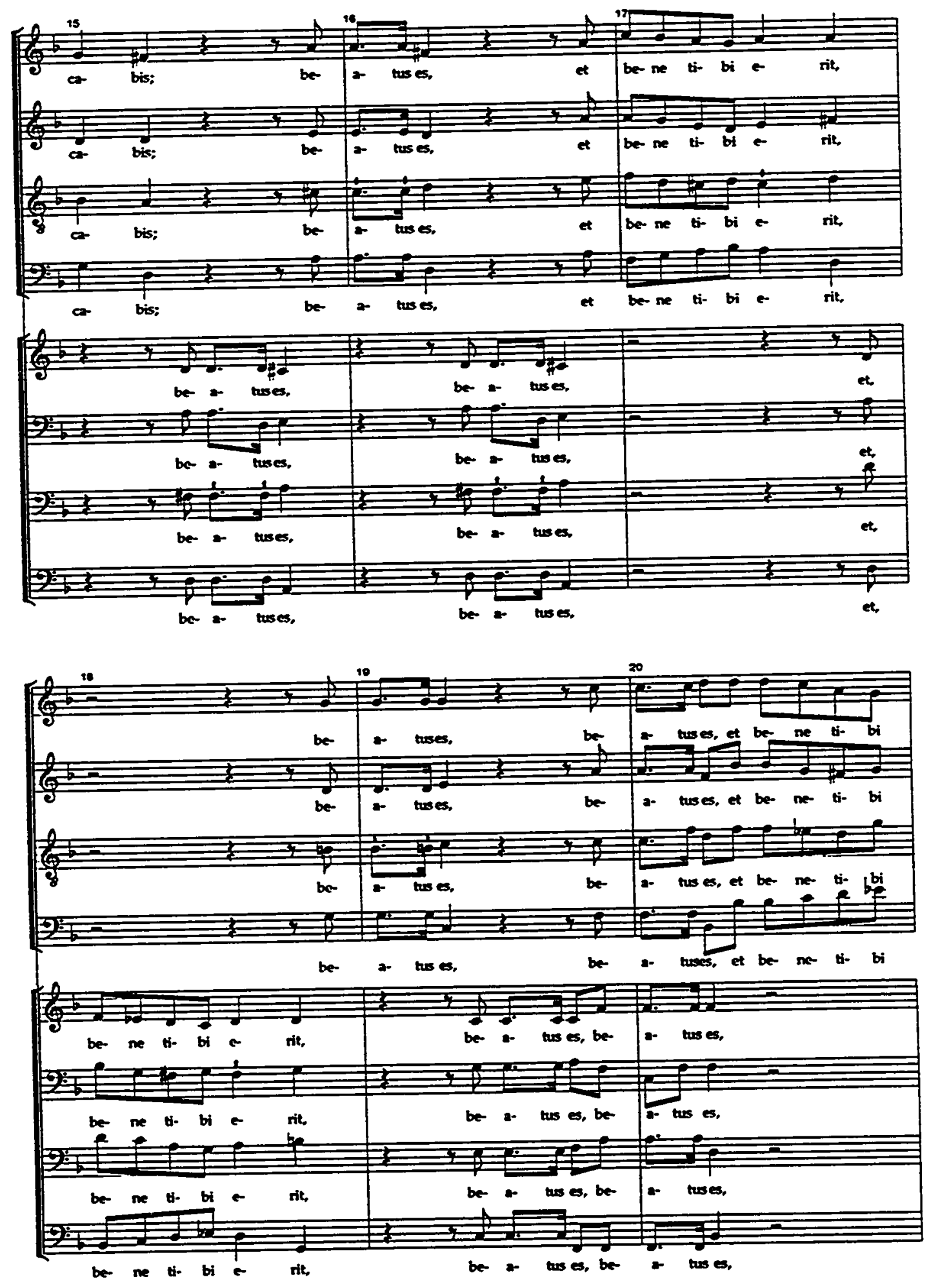

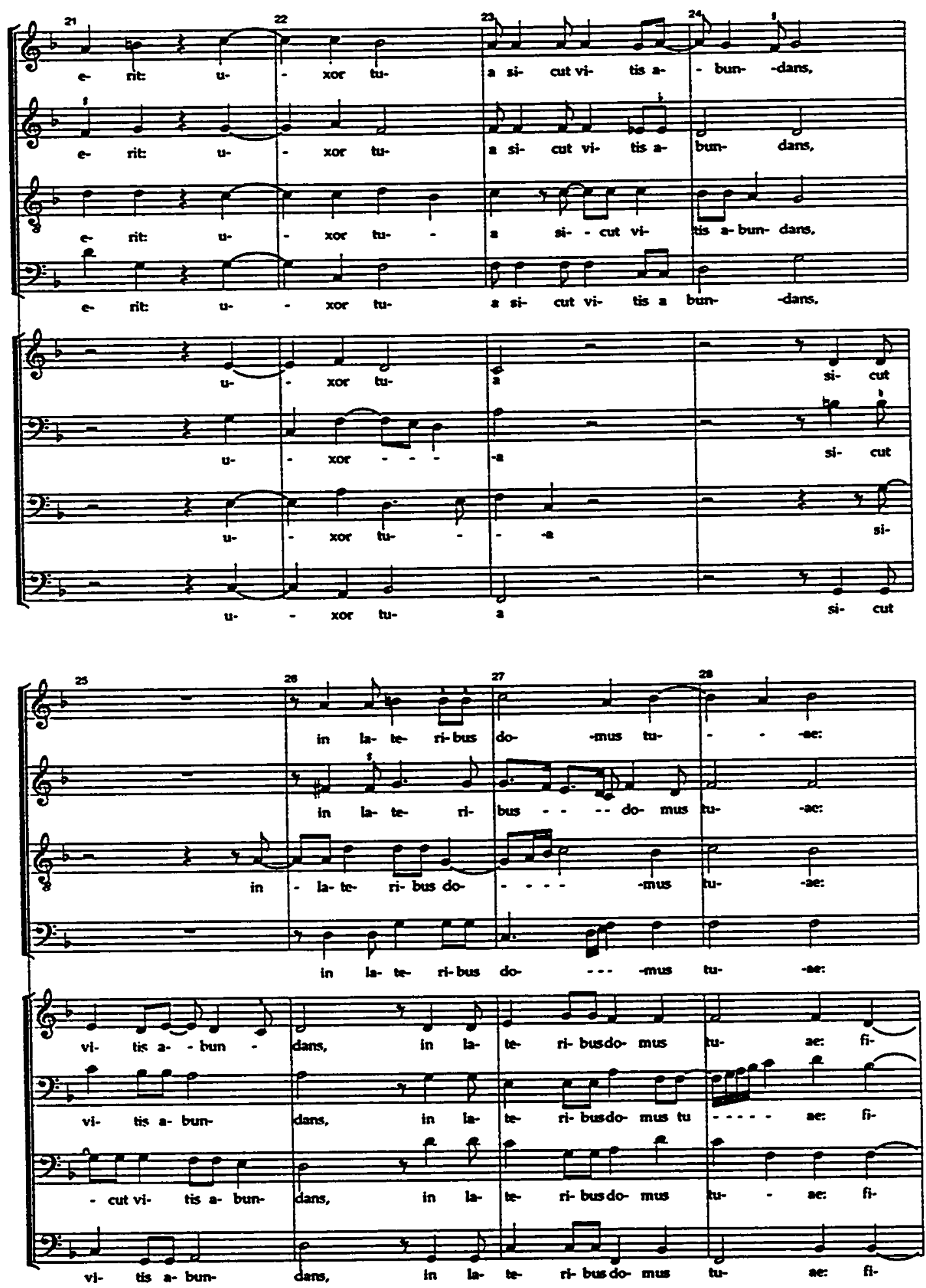

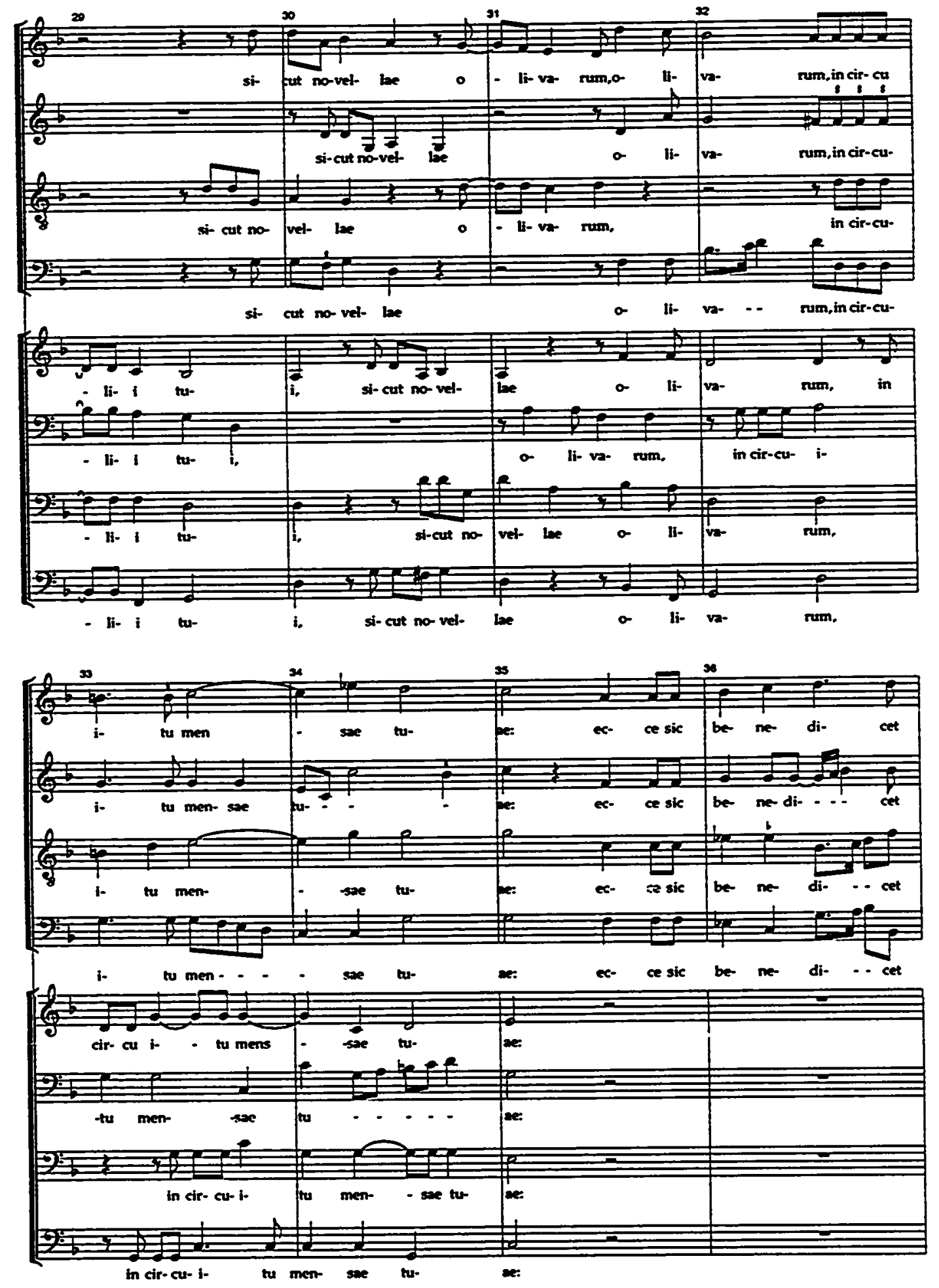

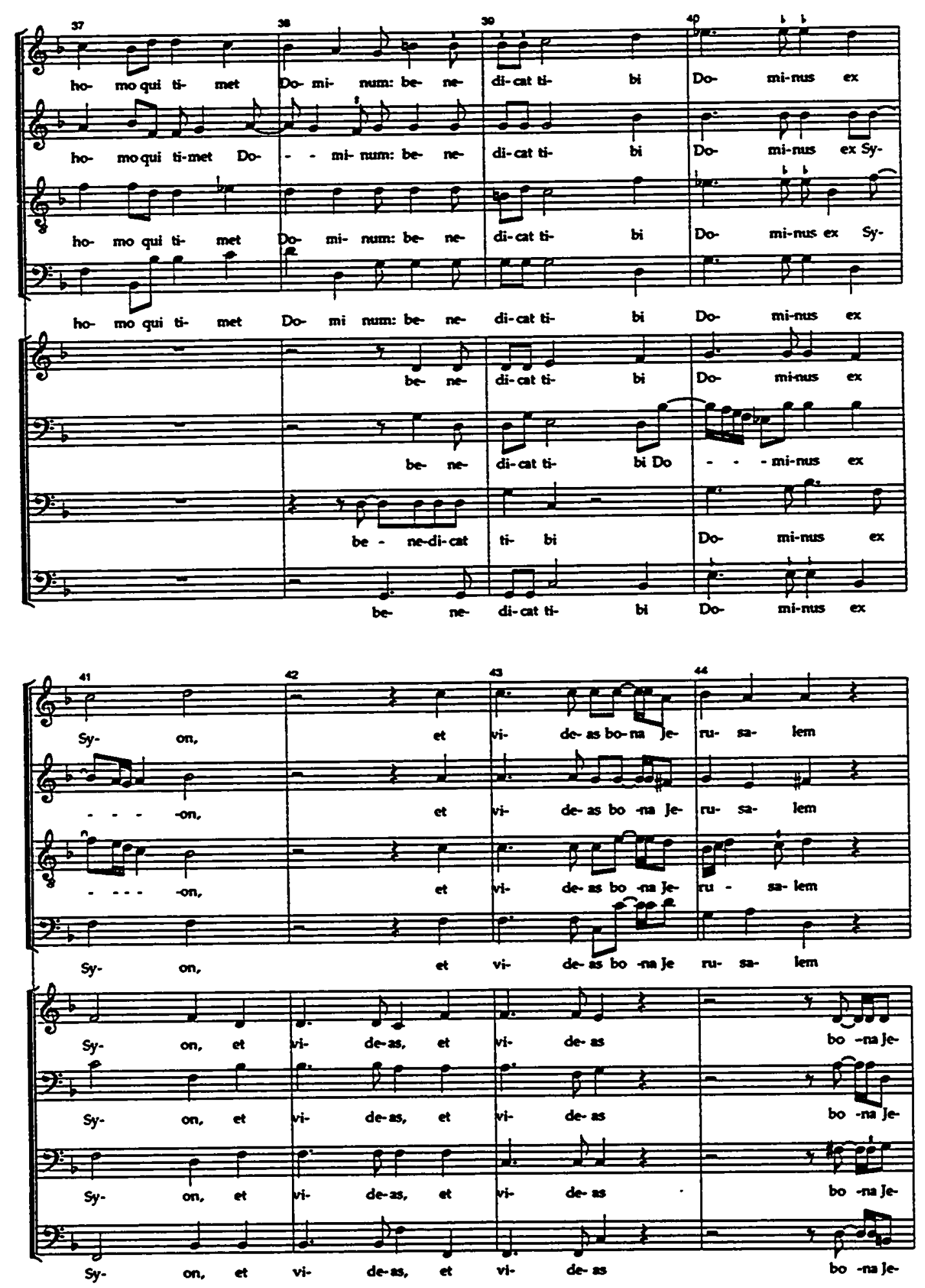

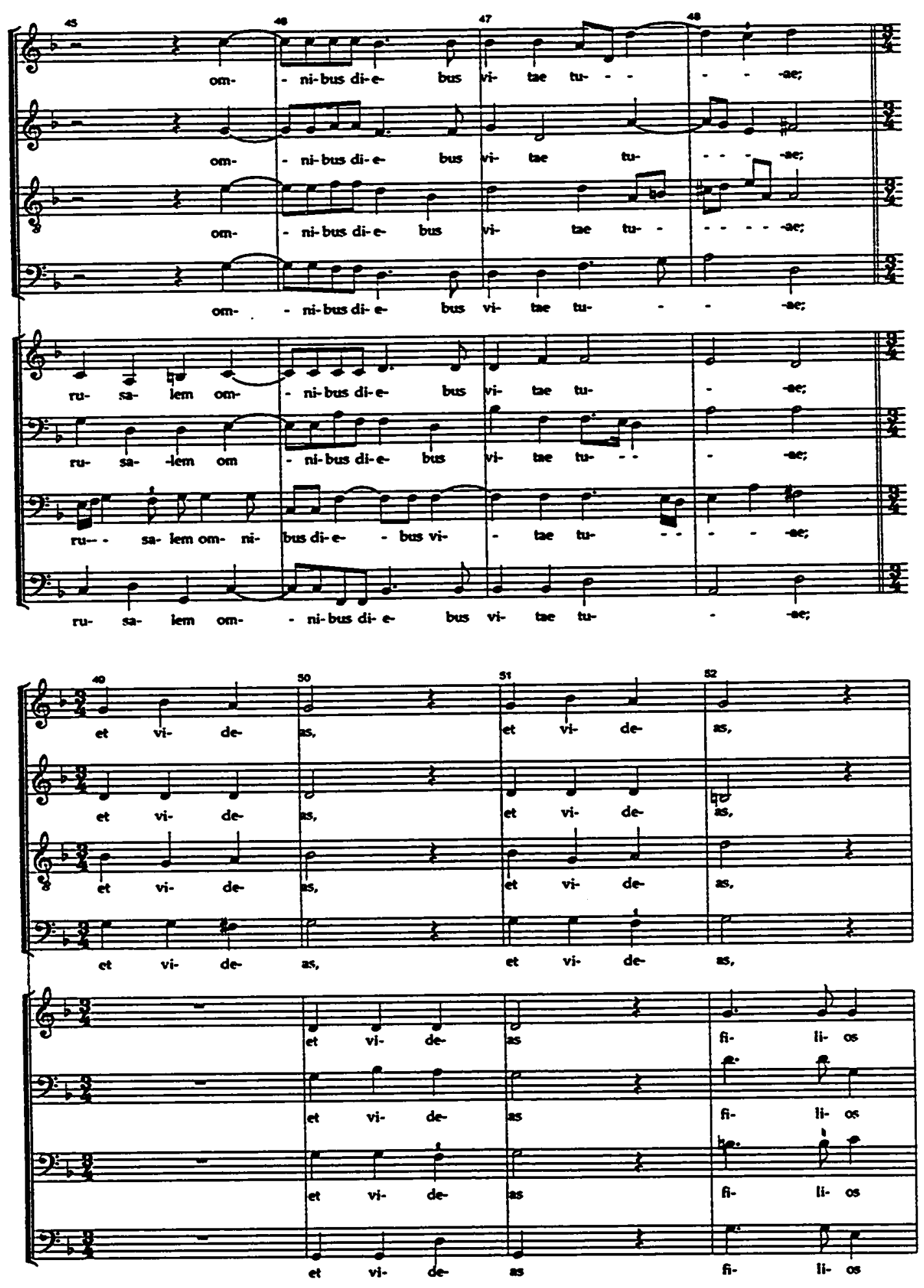

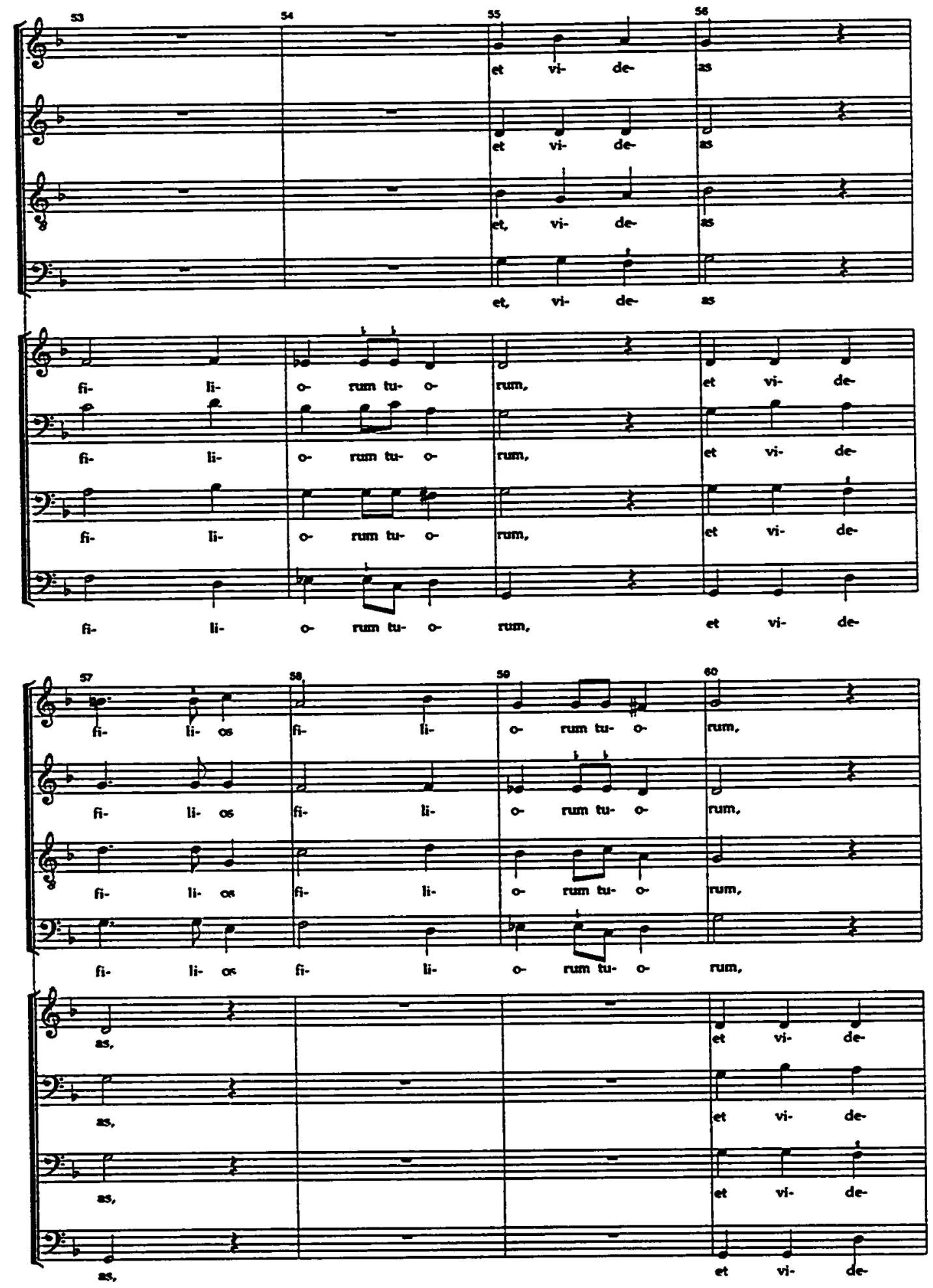

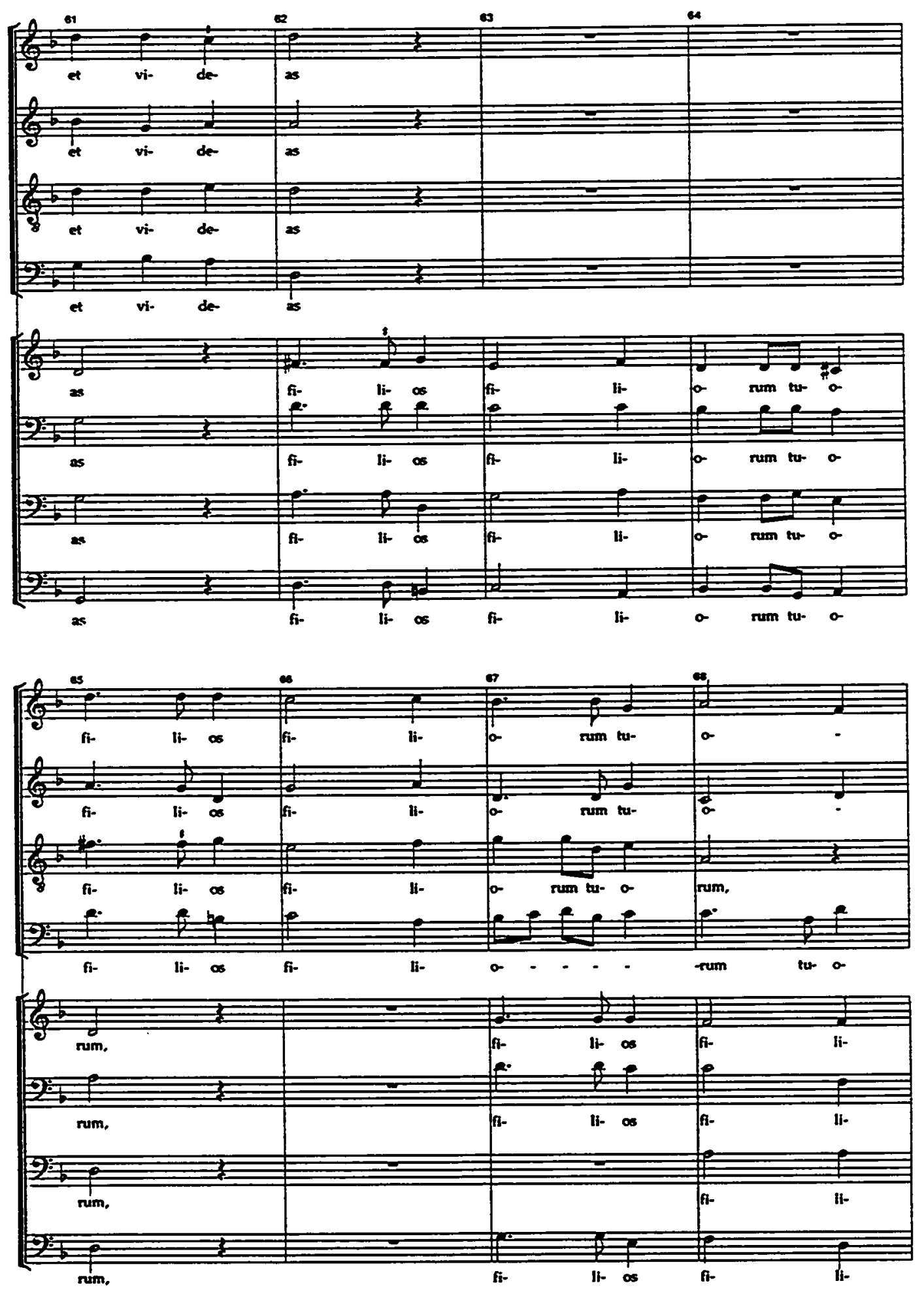

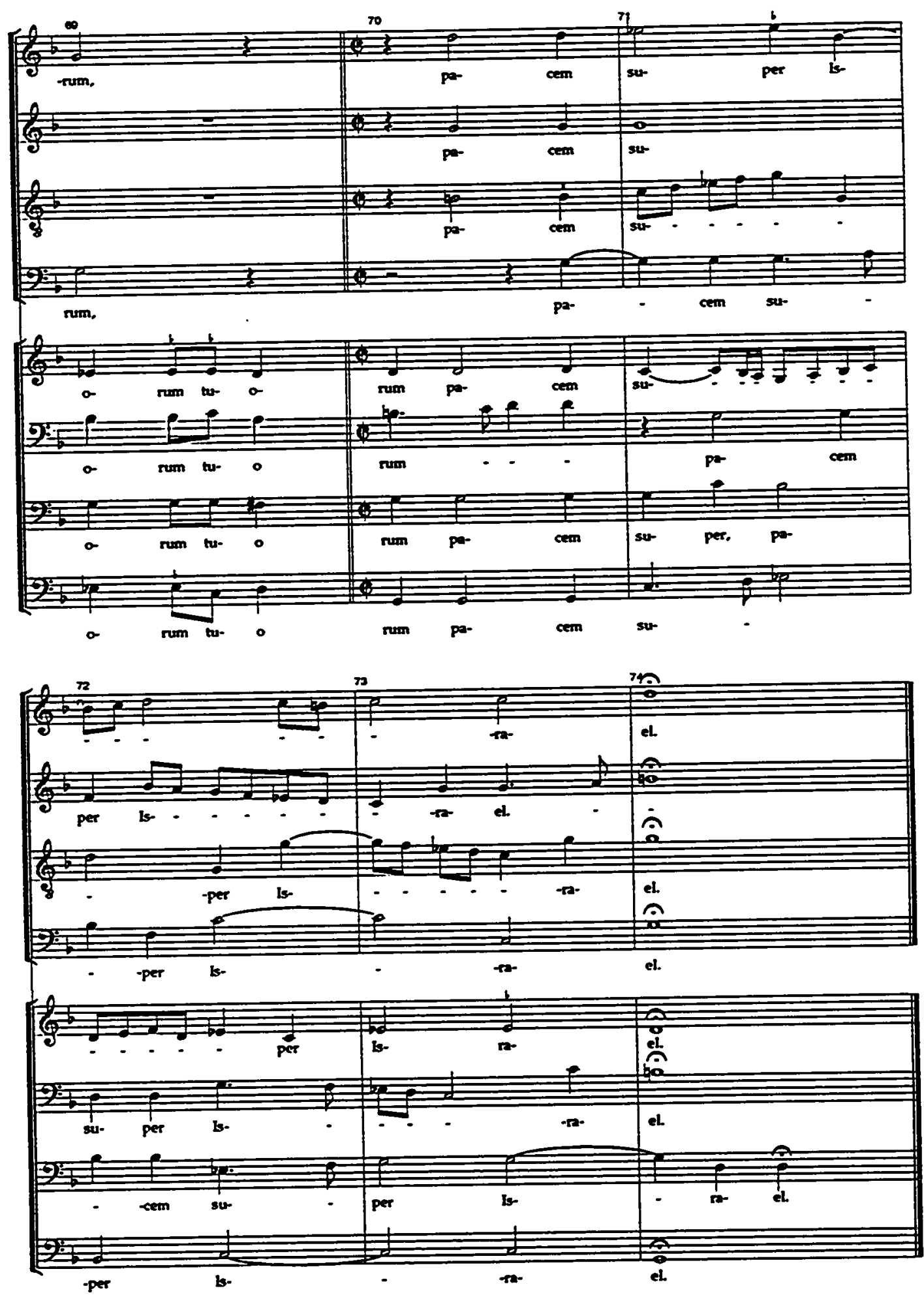

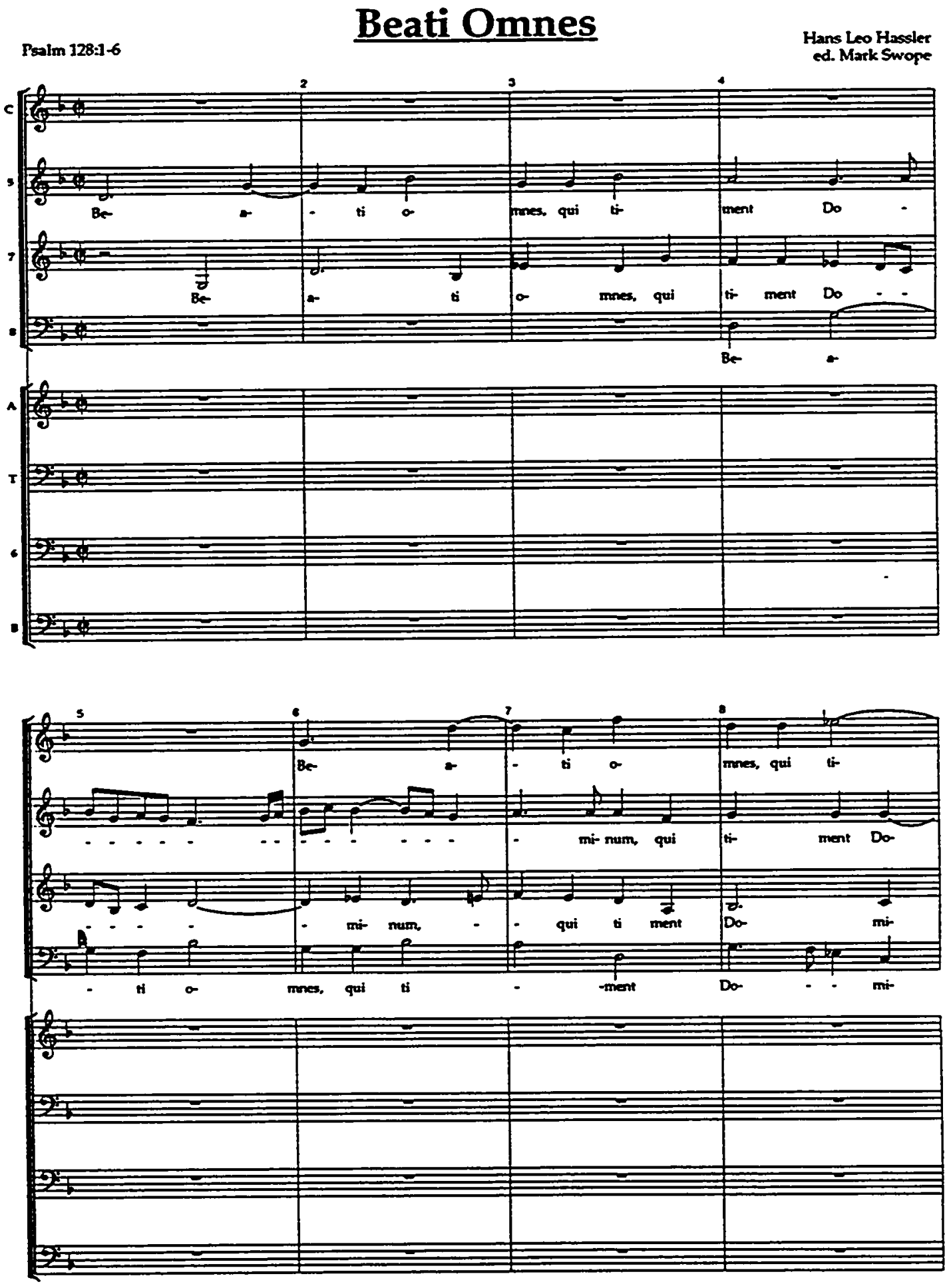

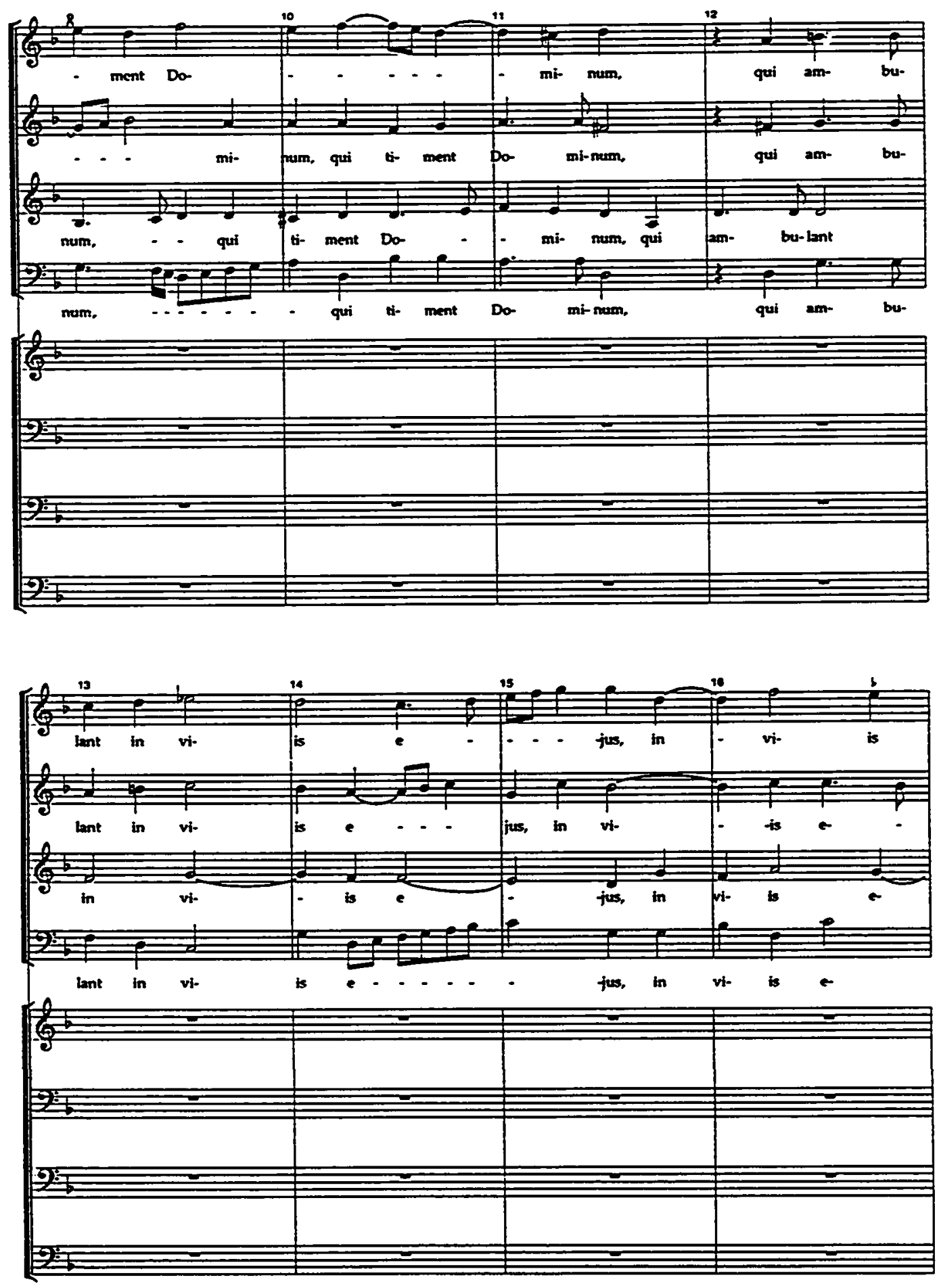

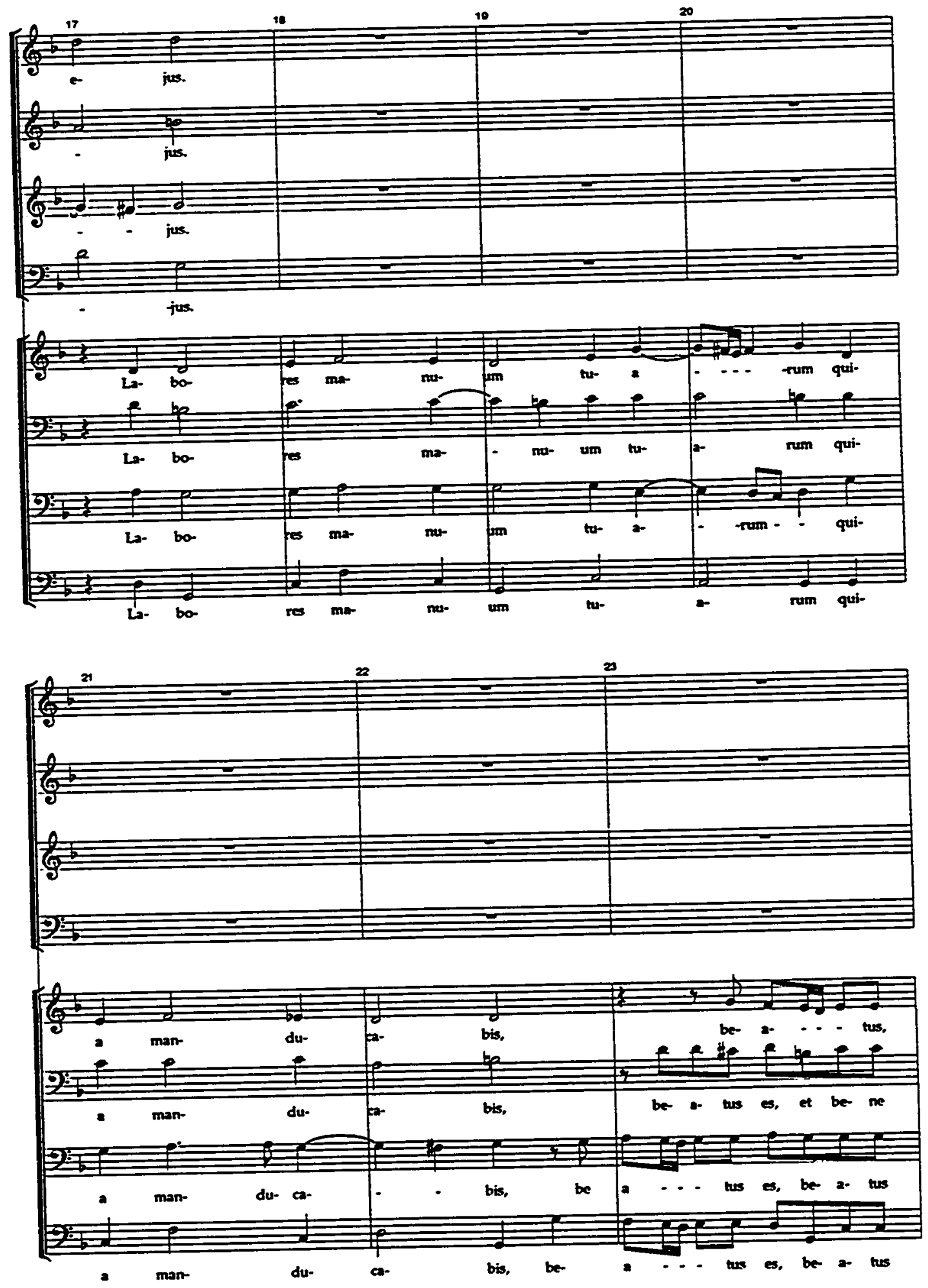

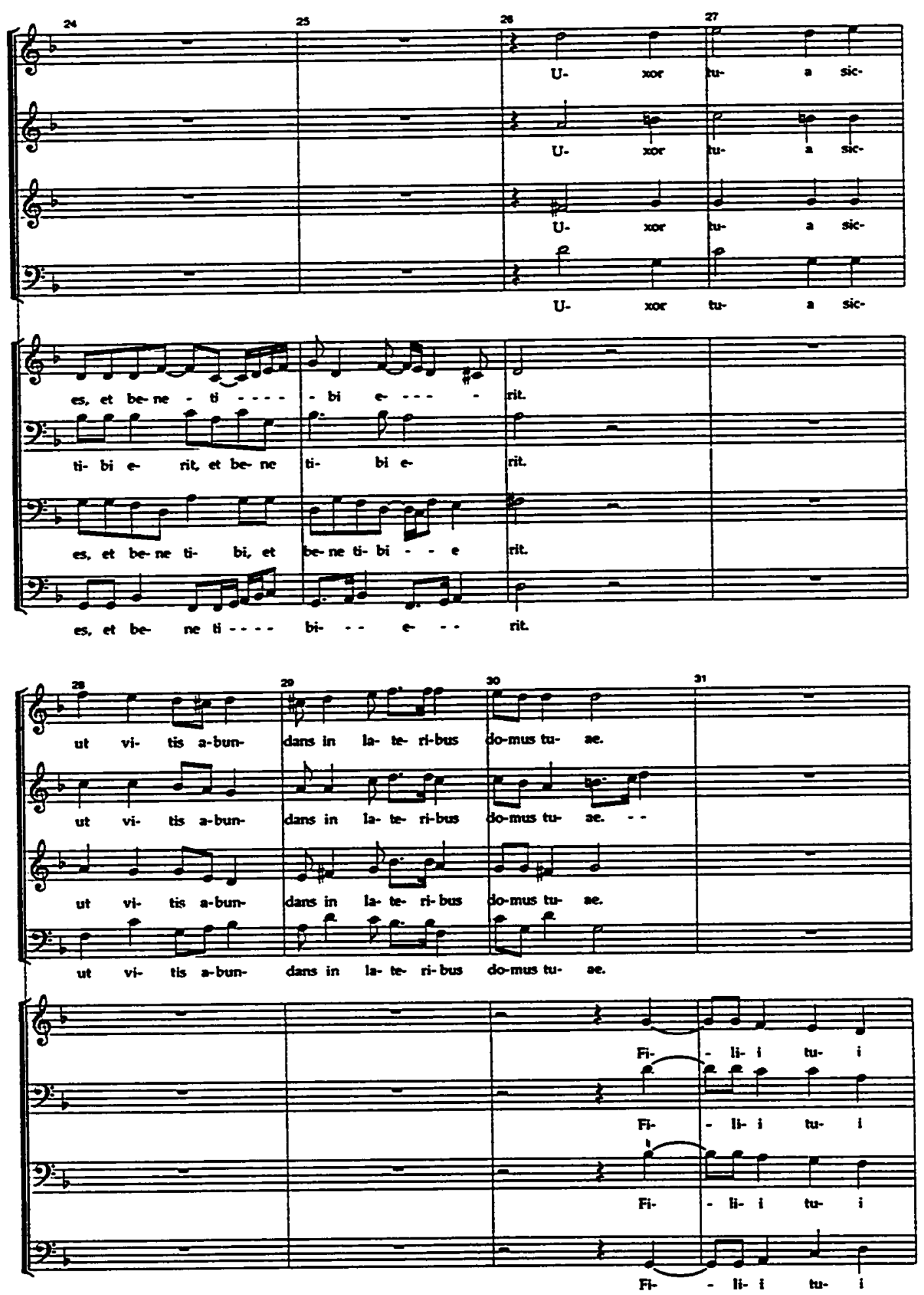

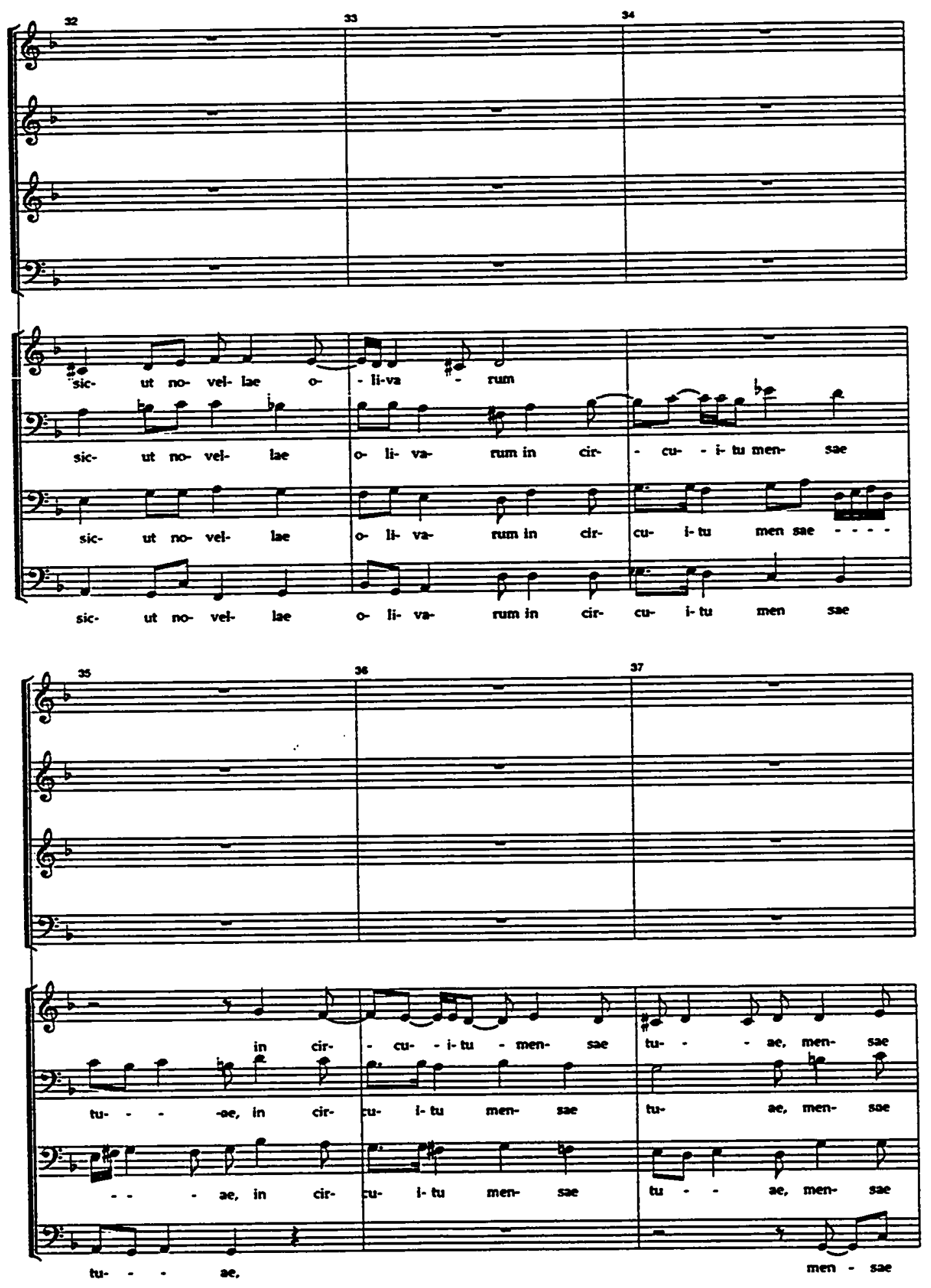

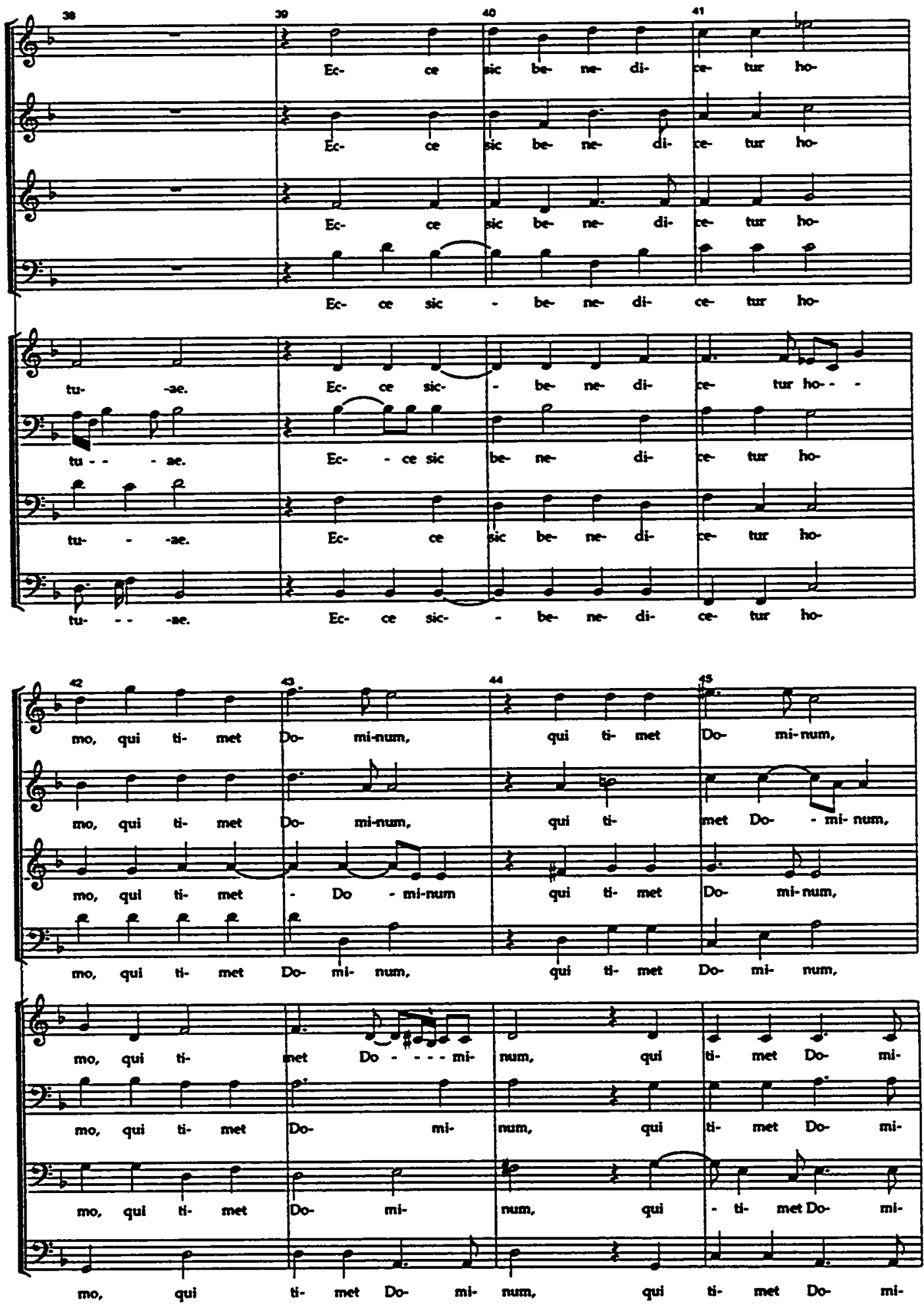

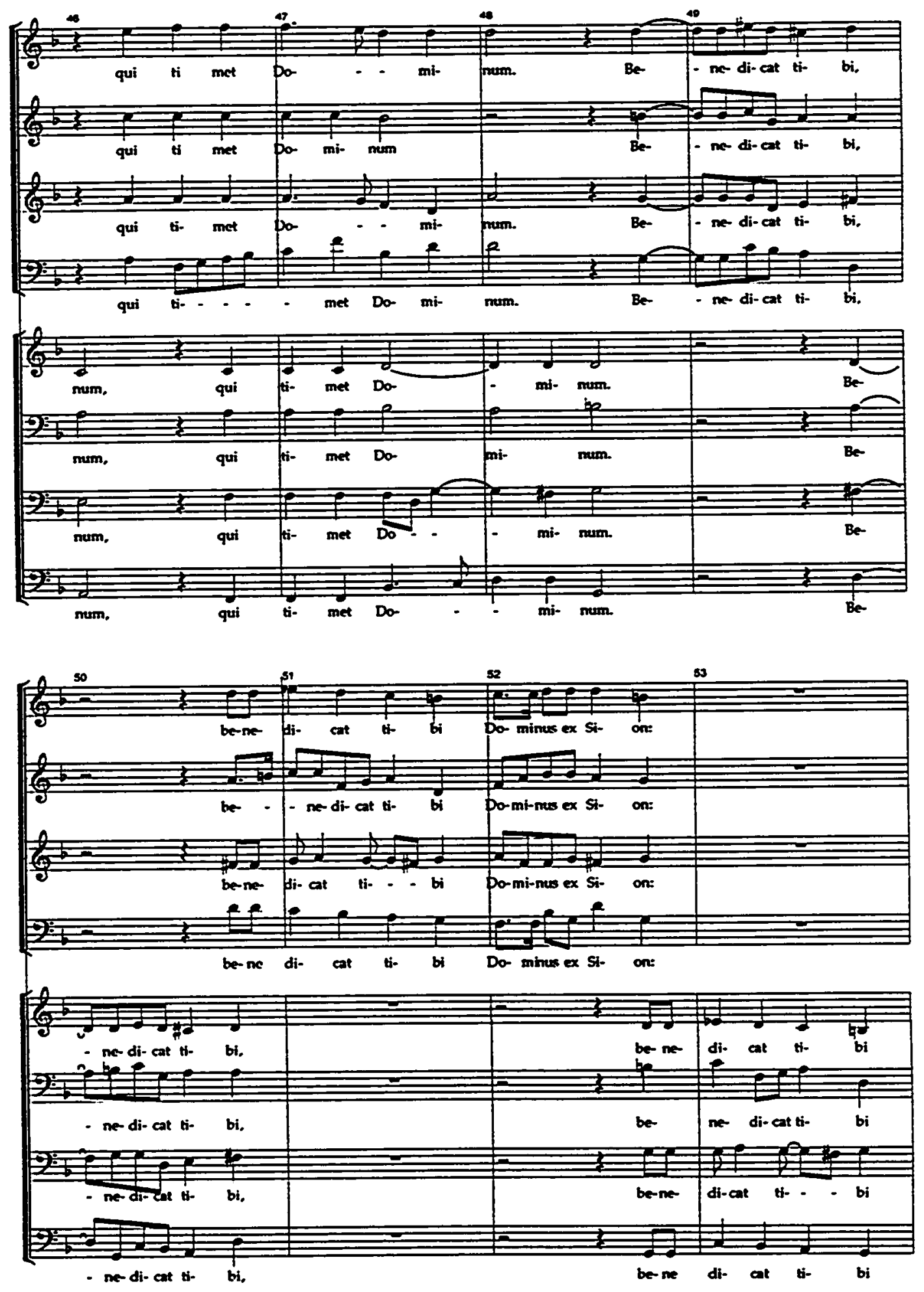

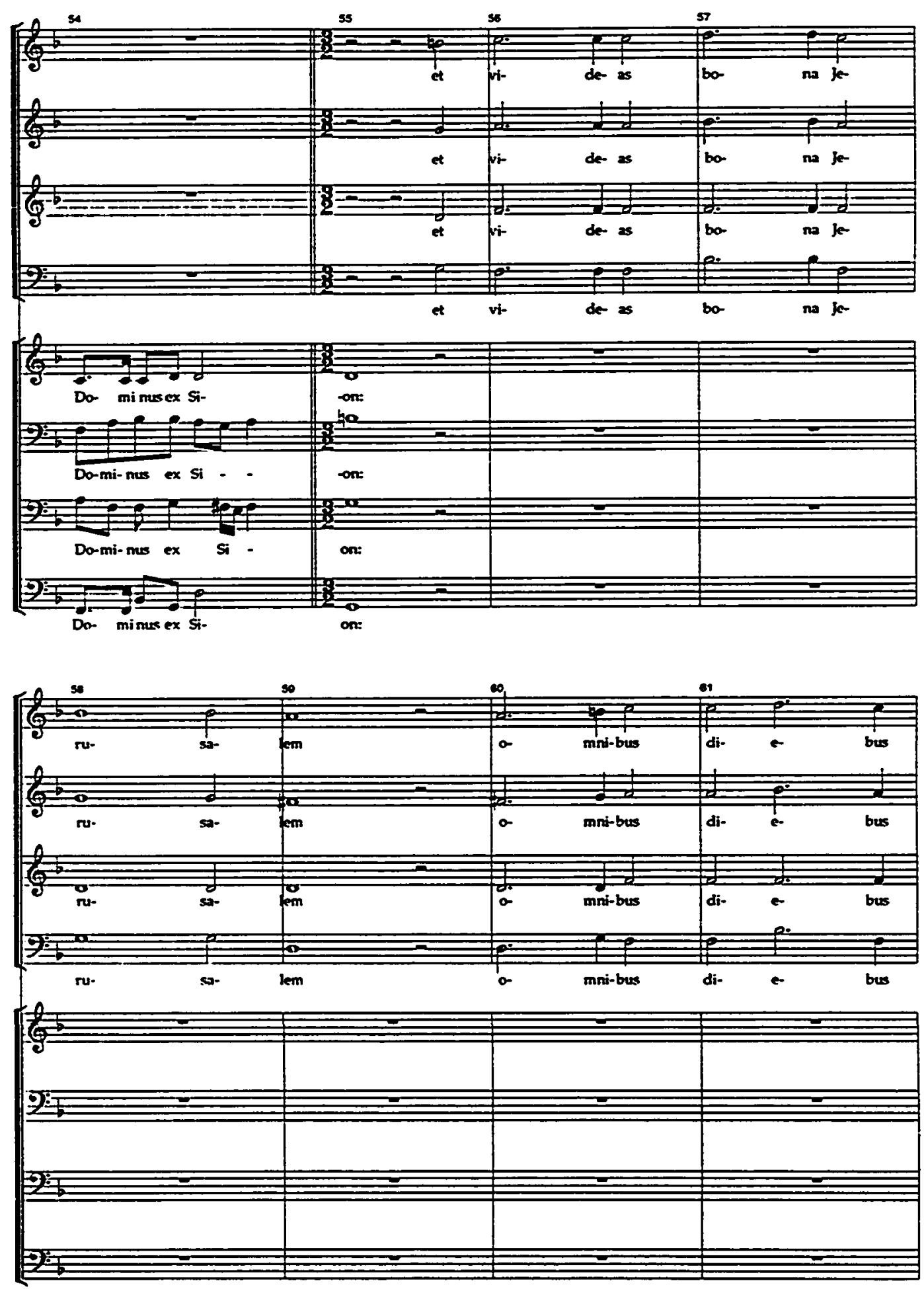

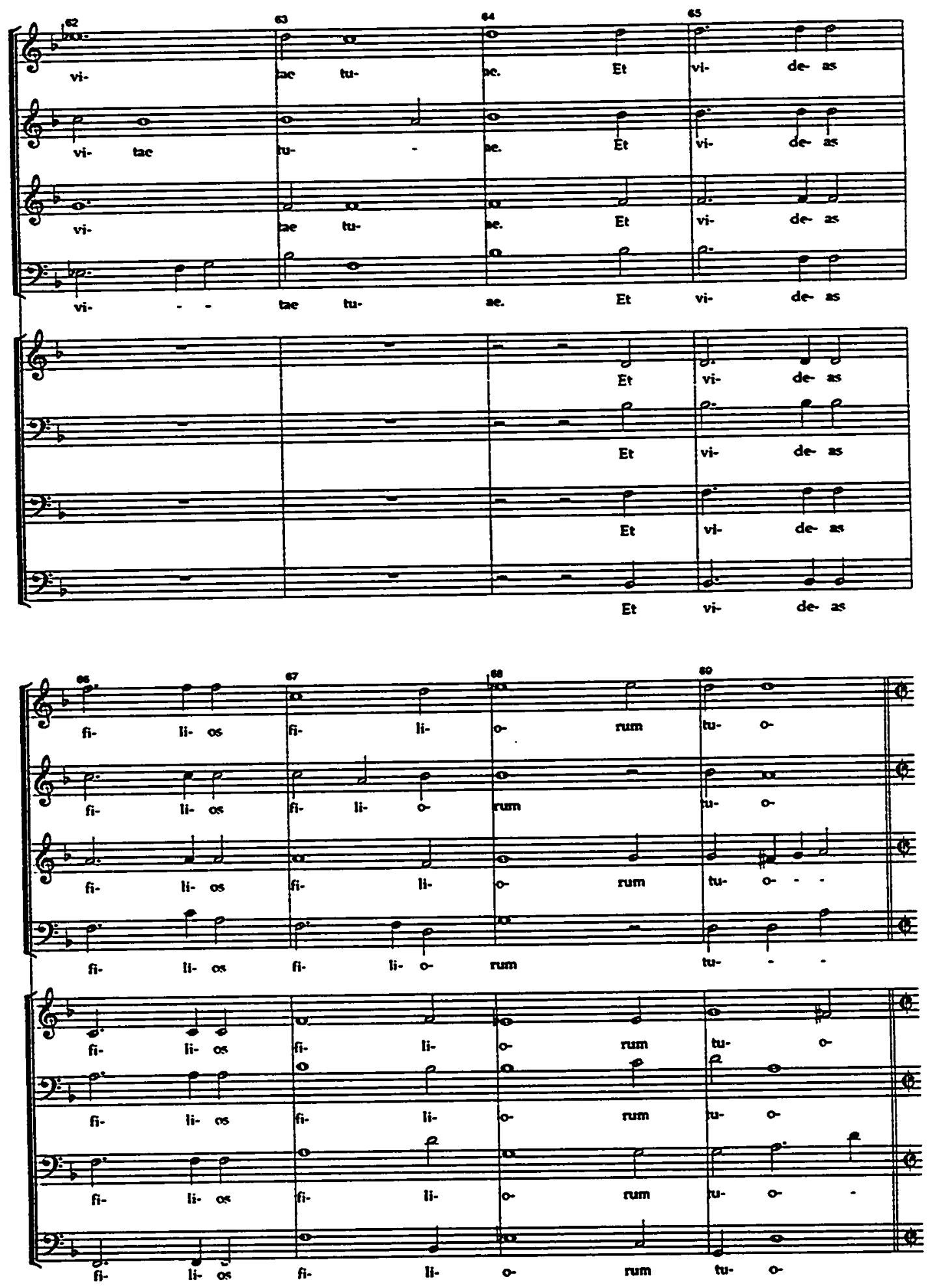

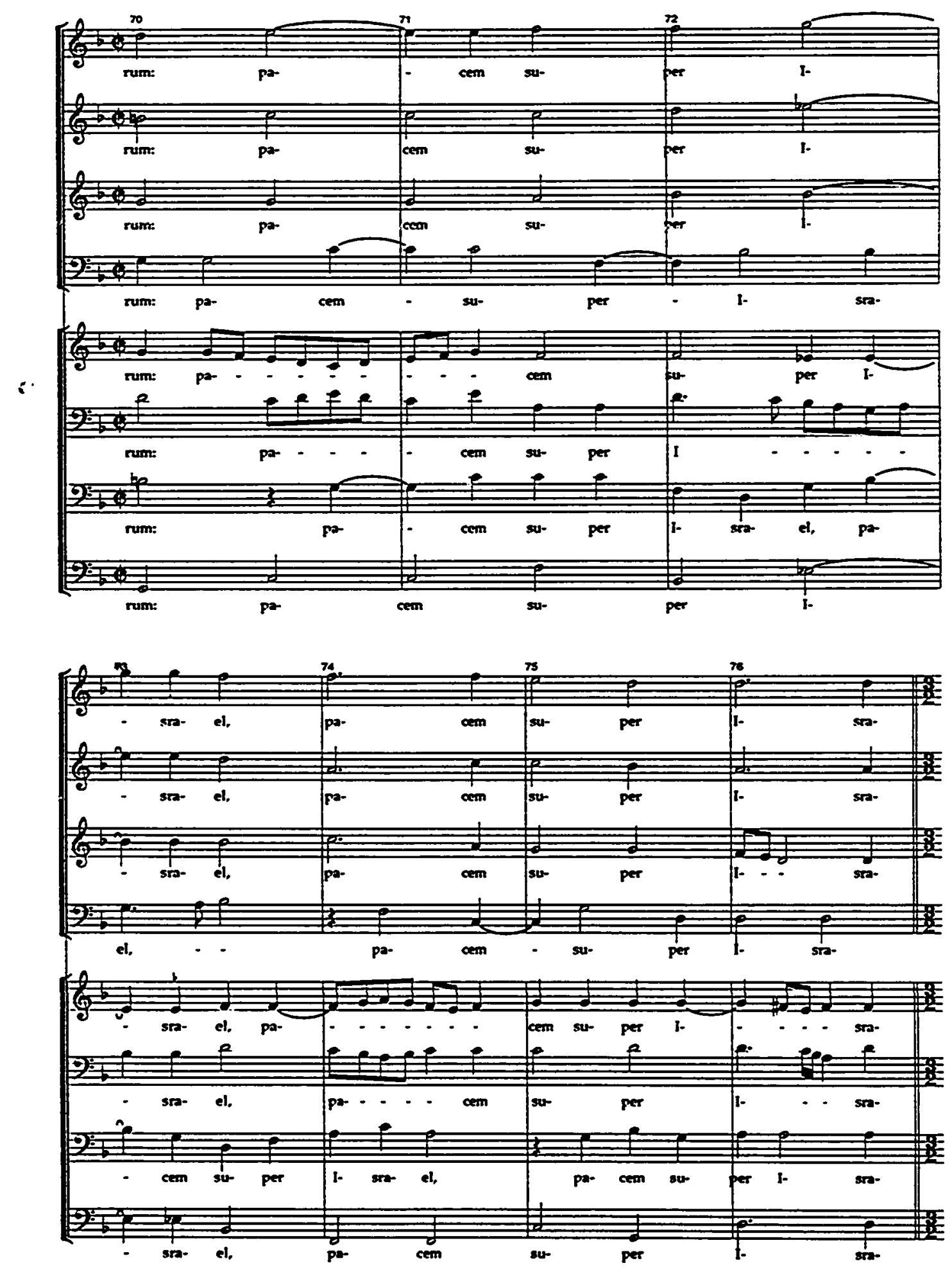



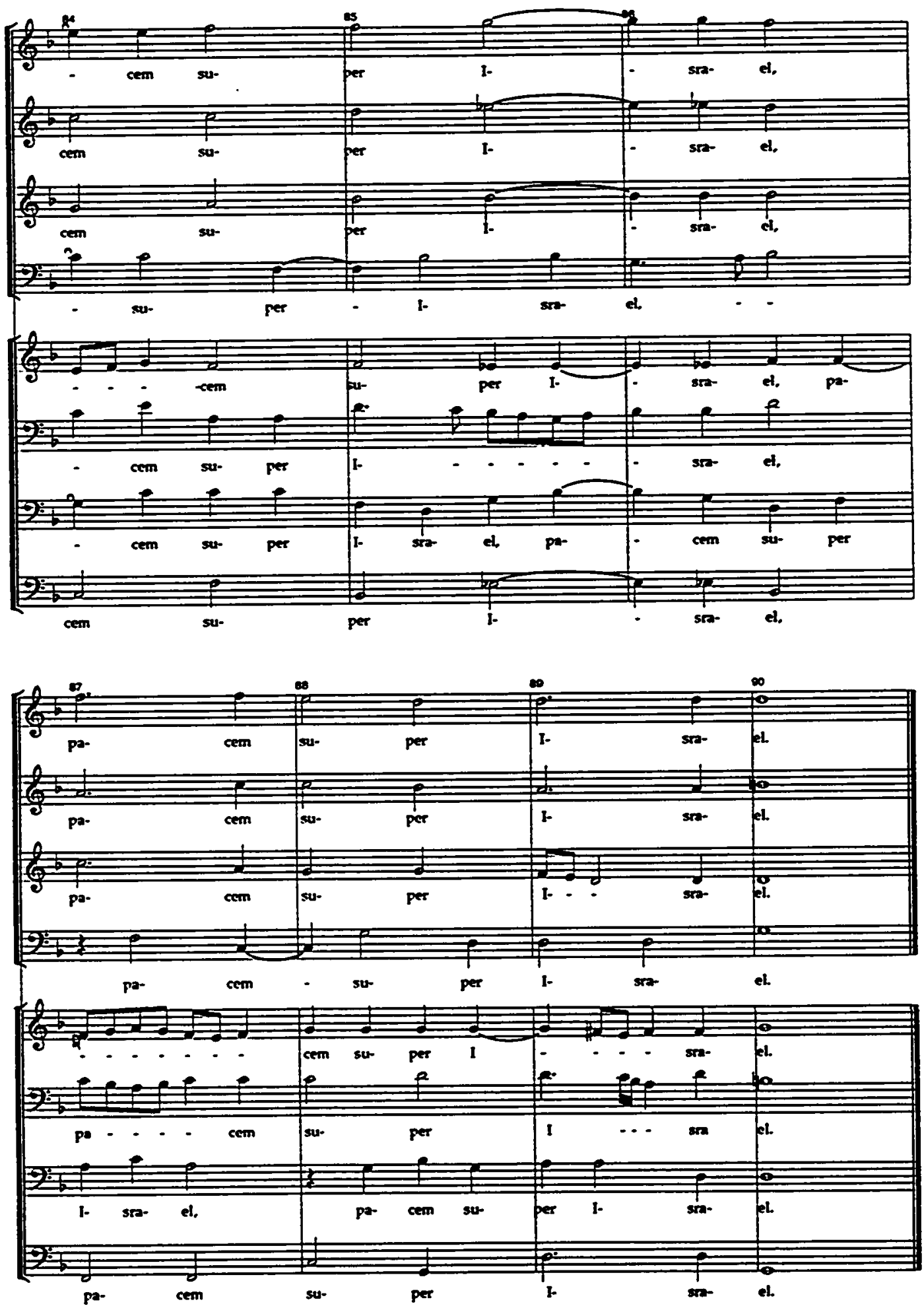


\section{Jubilate Deo}

Giovanni Gabrieli

Psalm 100:1-5

ed. Mark Swope

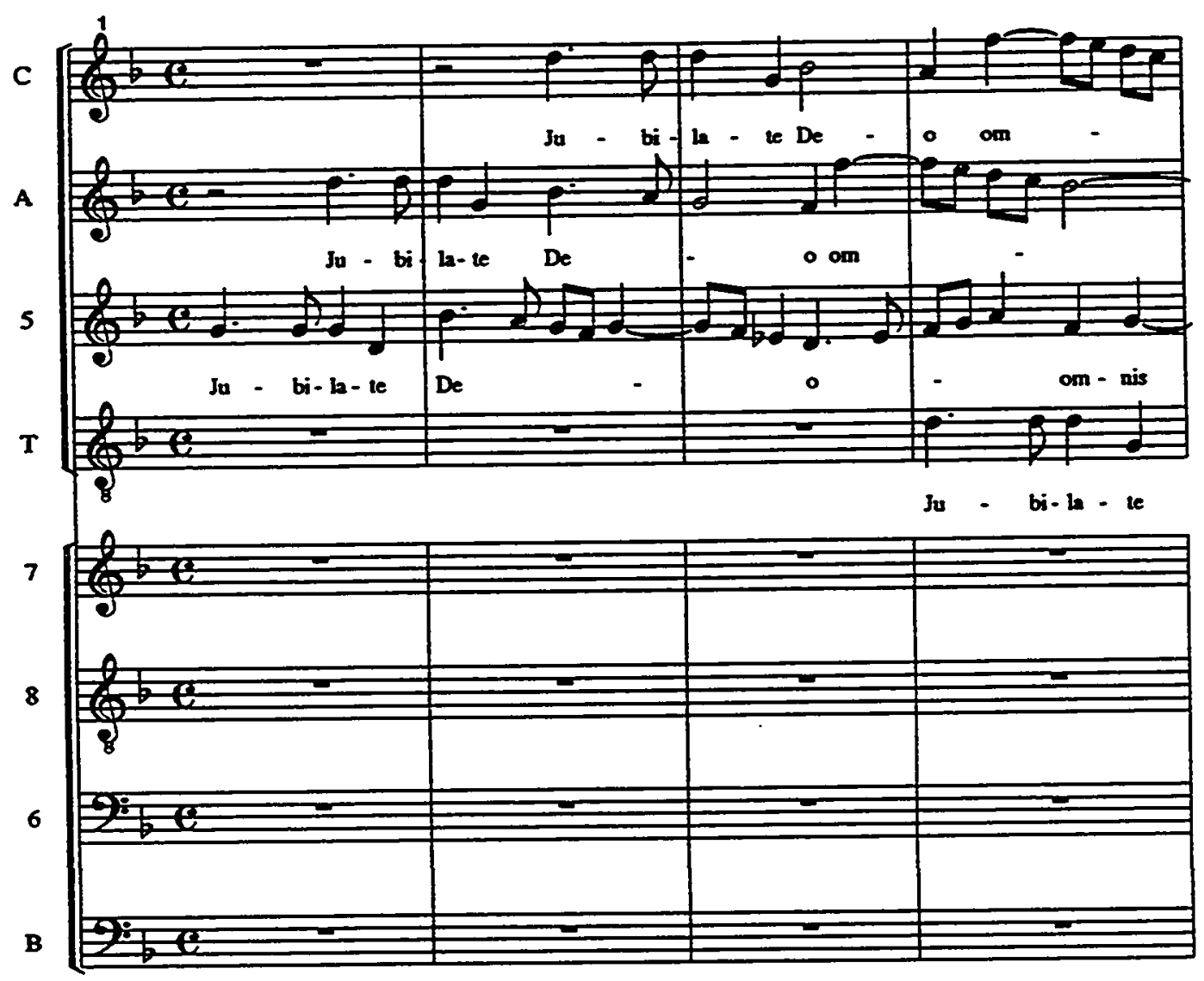



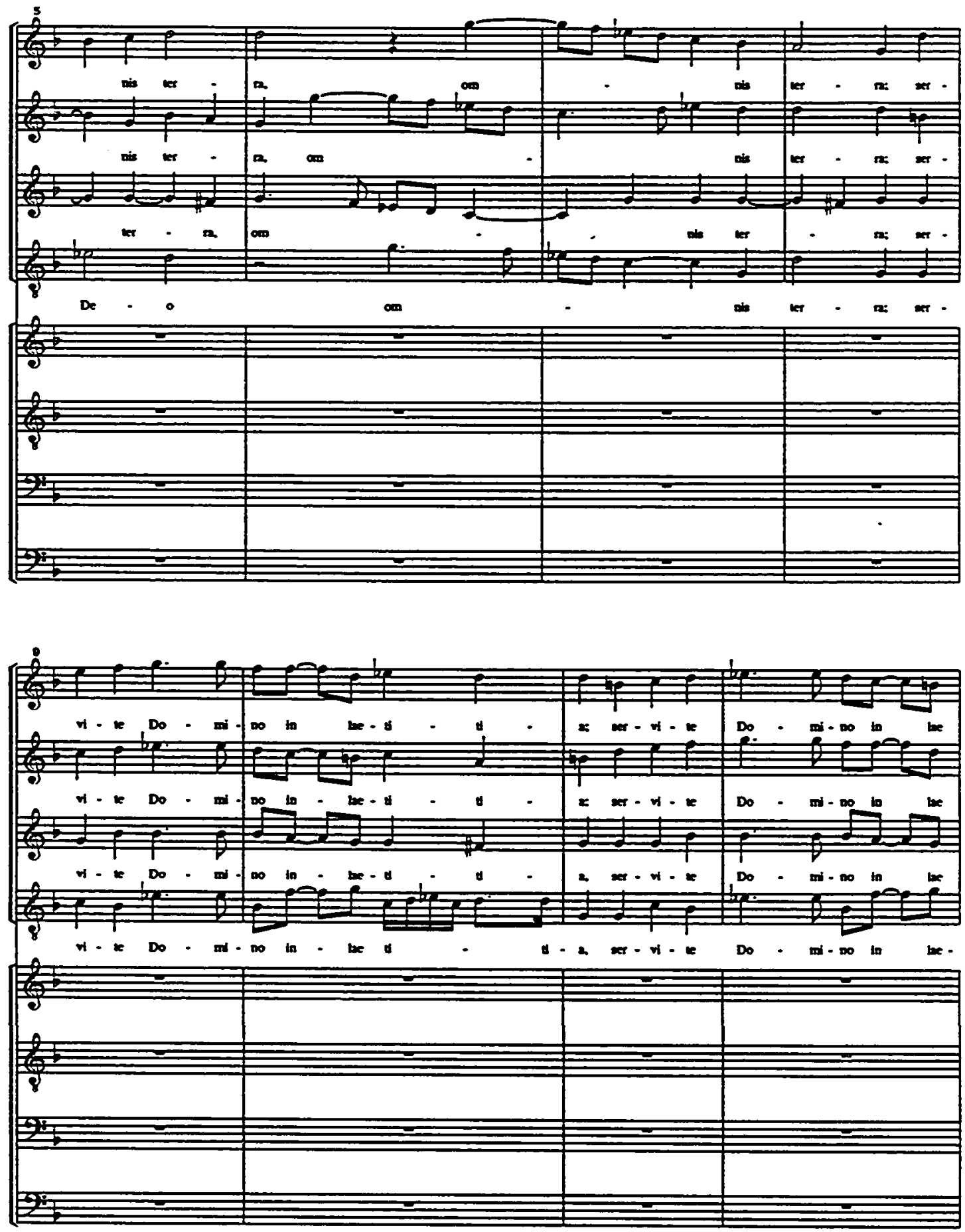

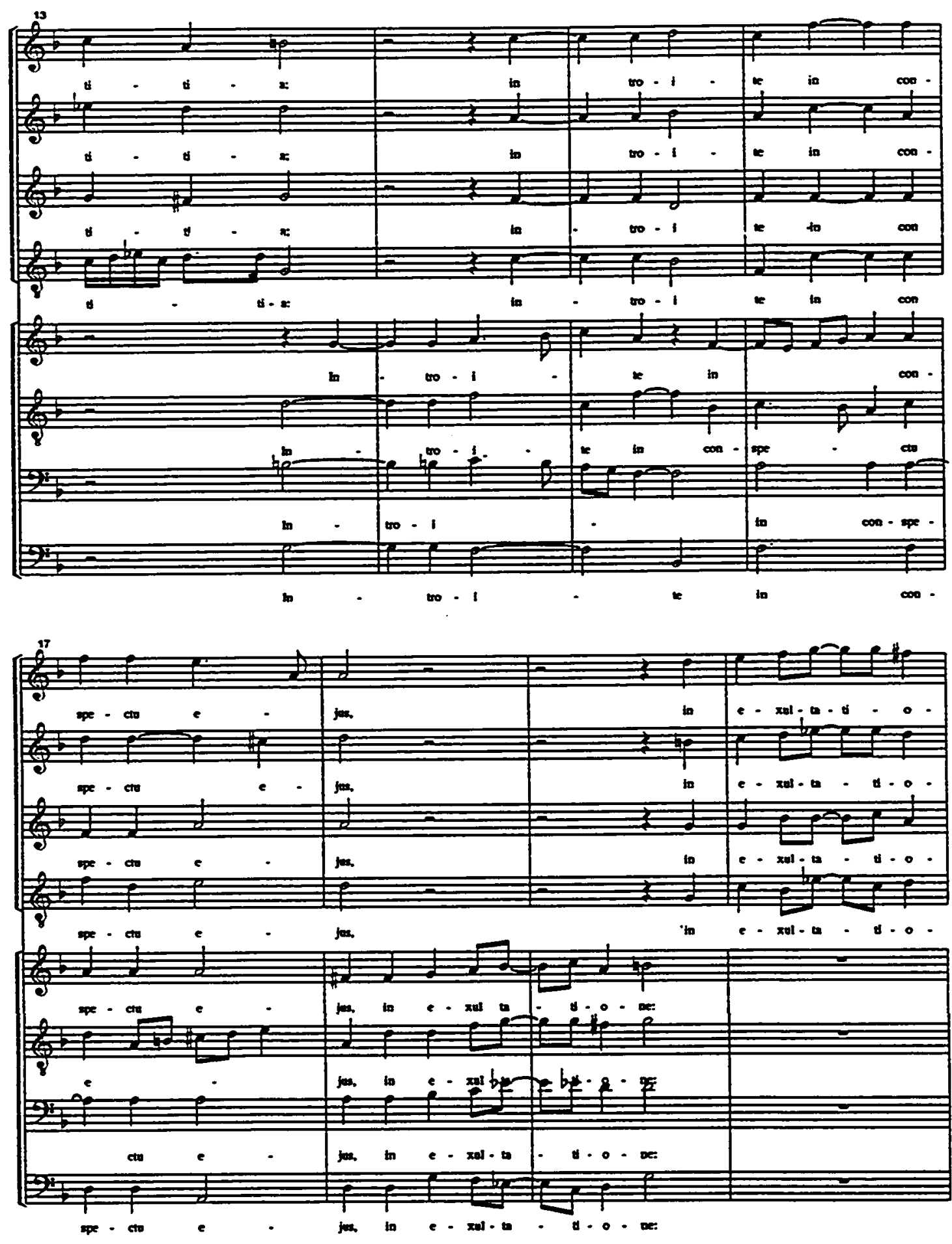

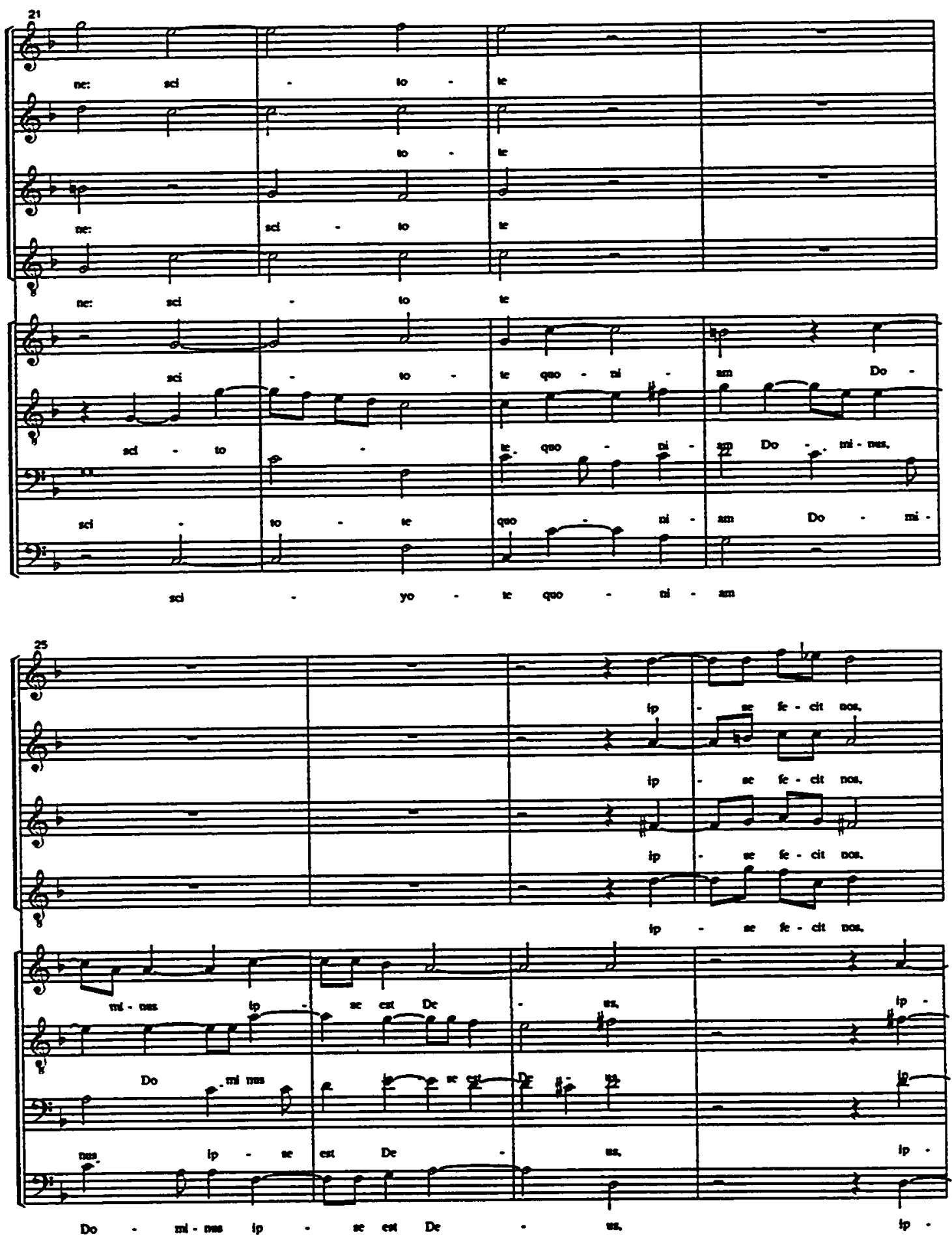

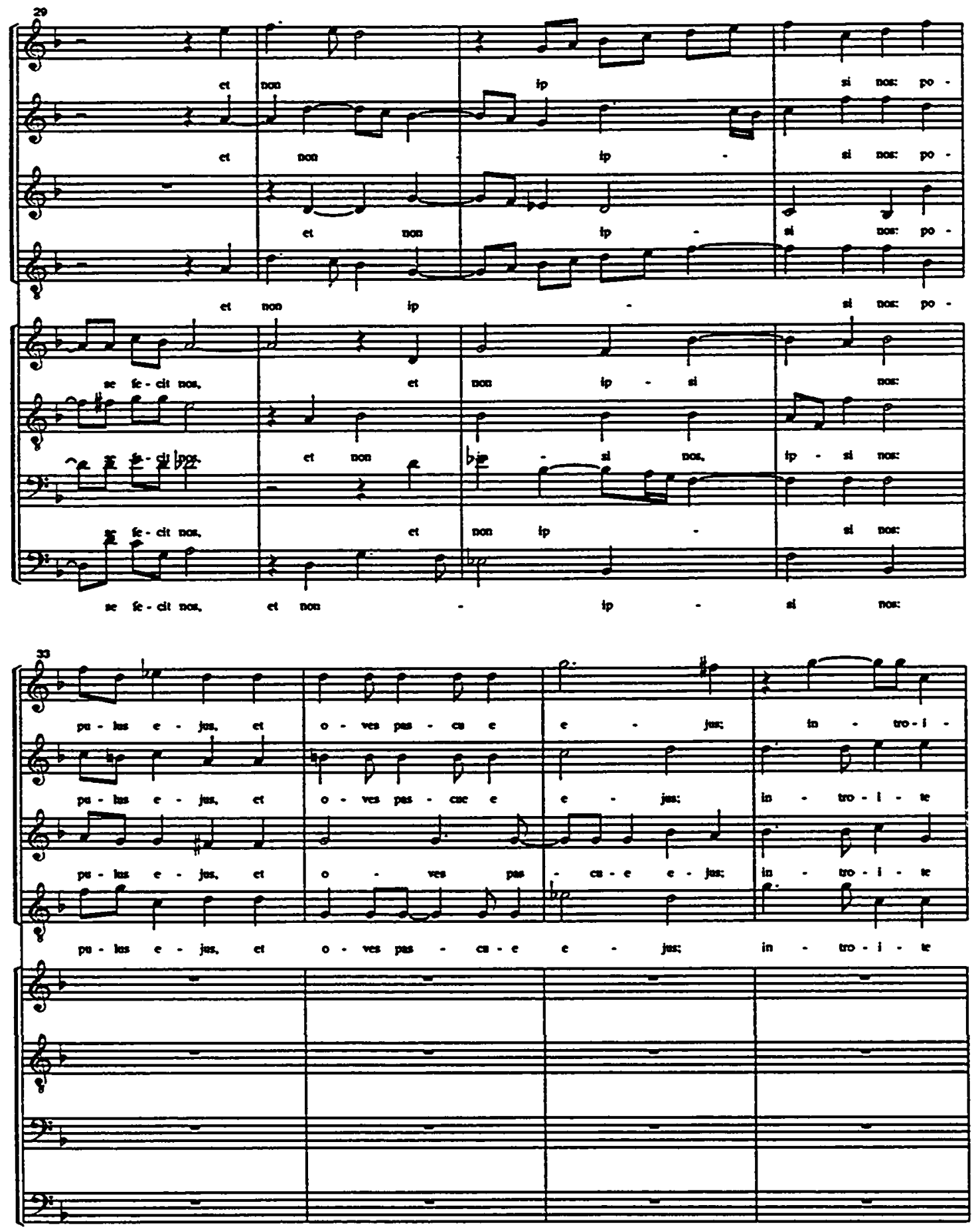

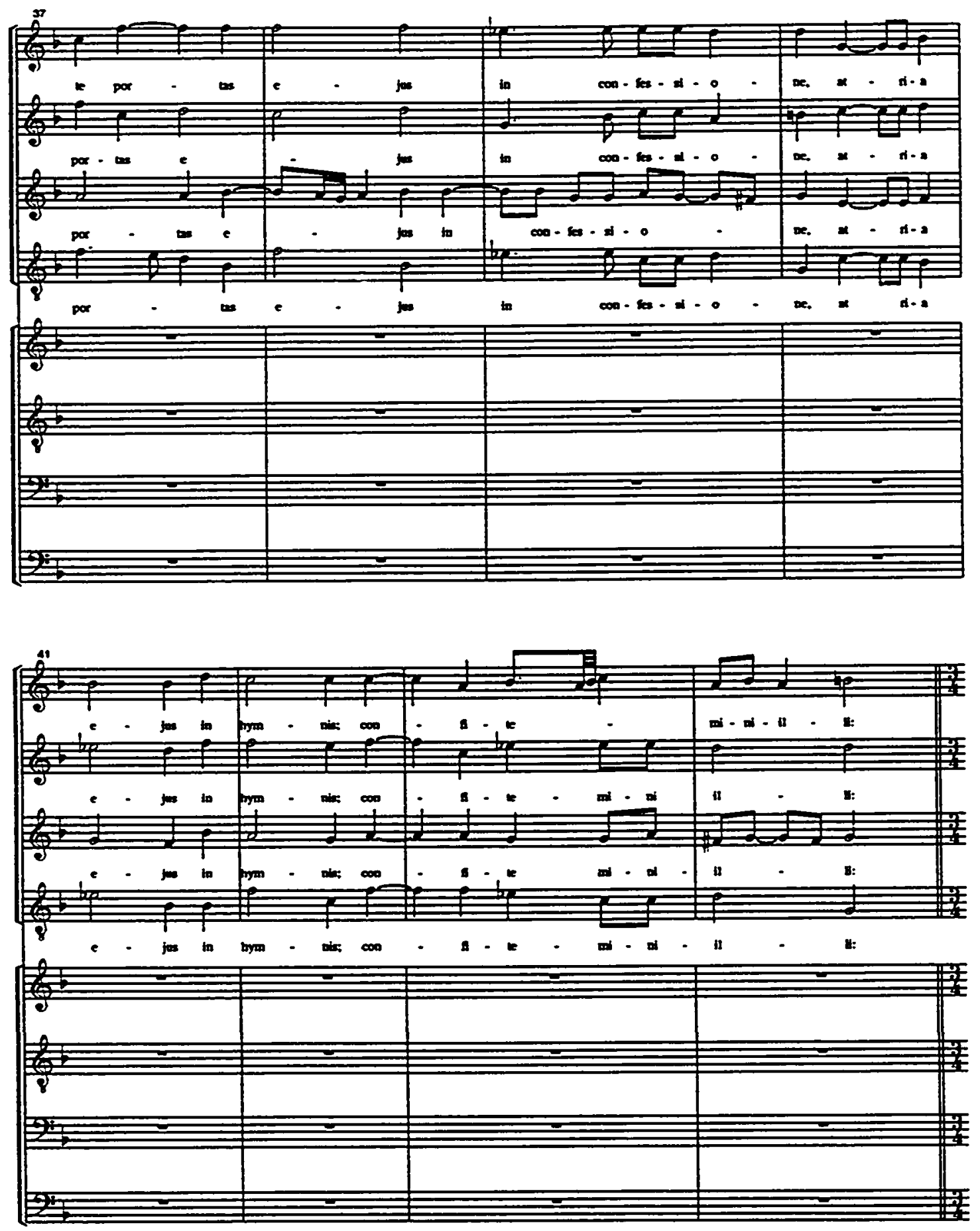

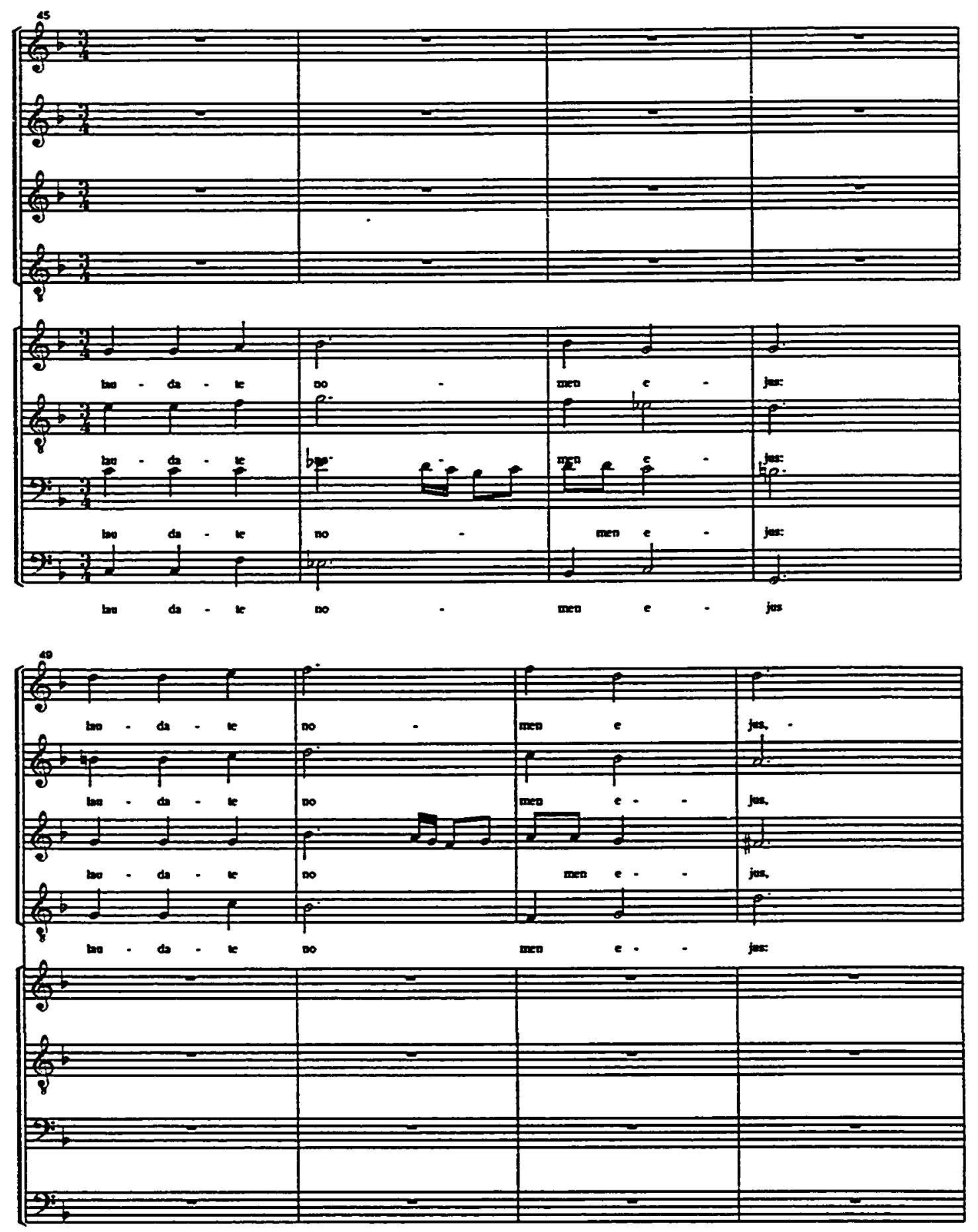

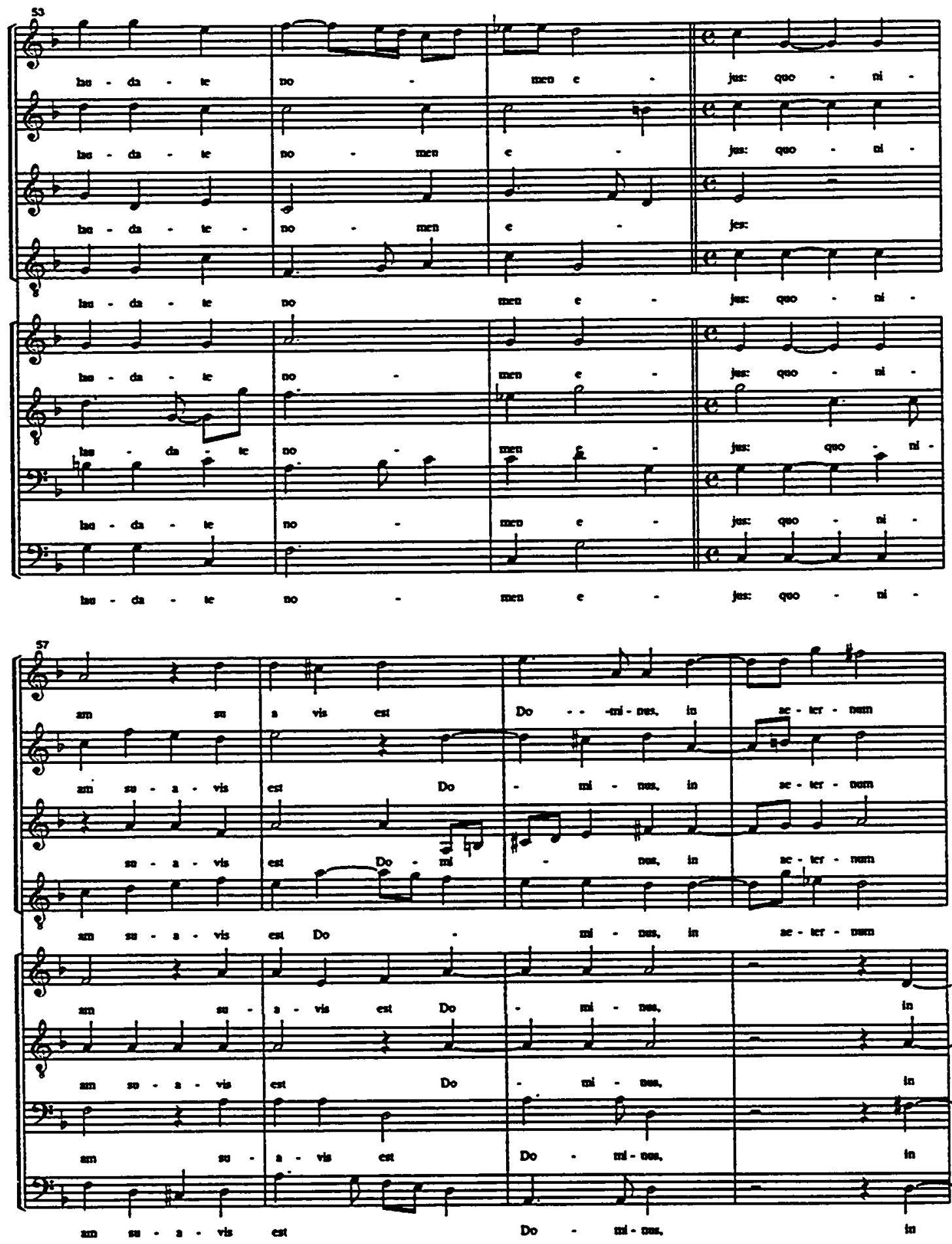

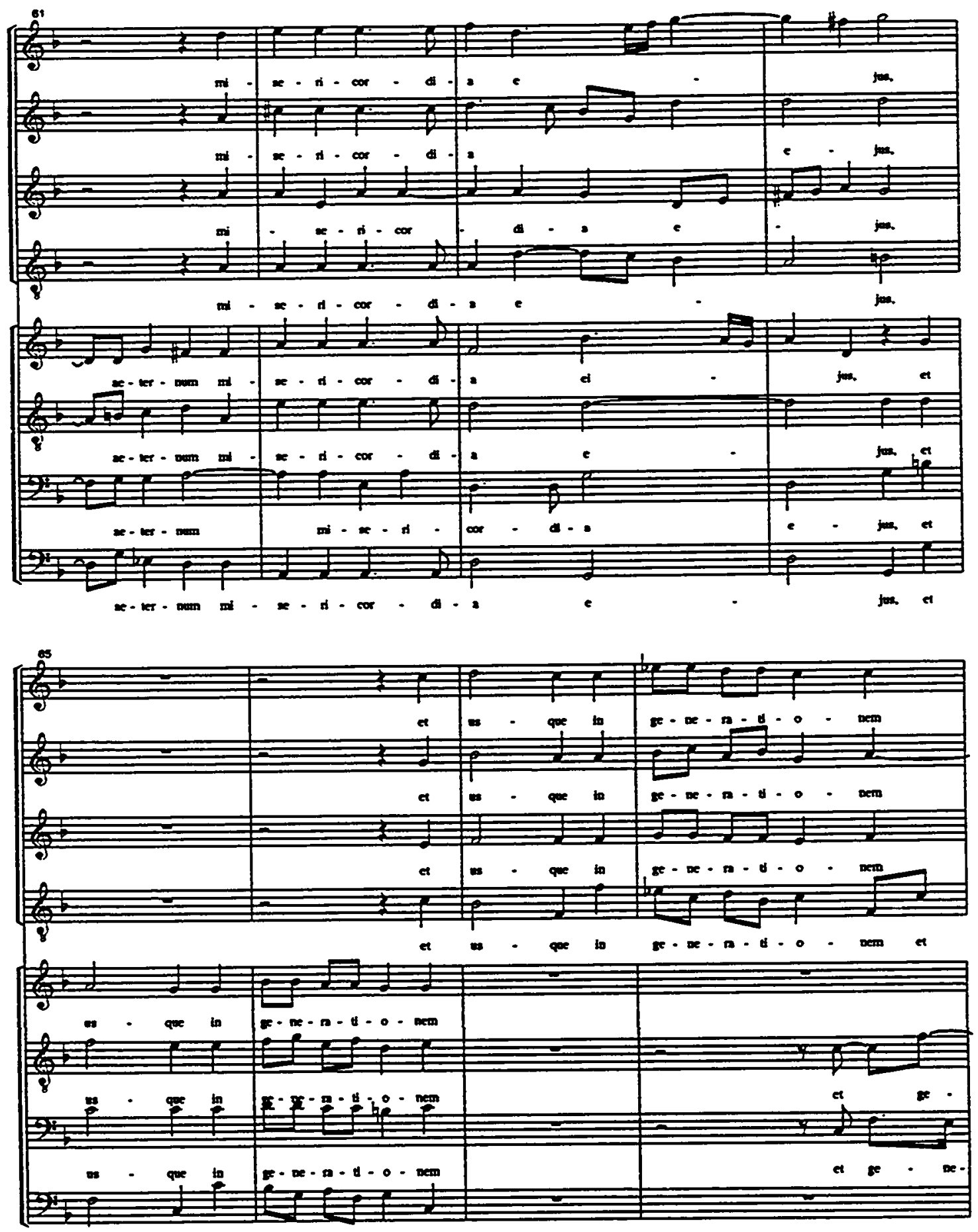

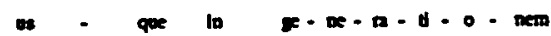



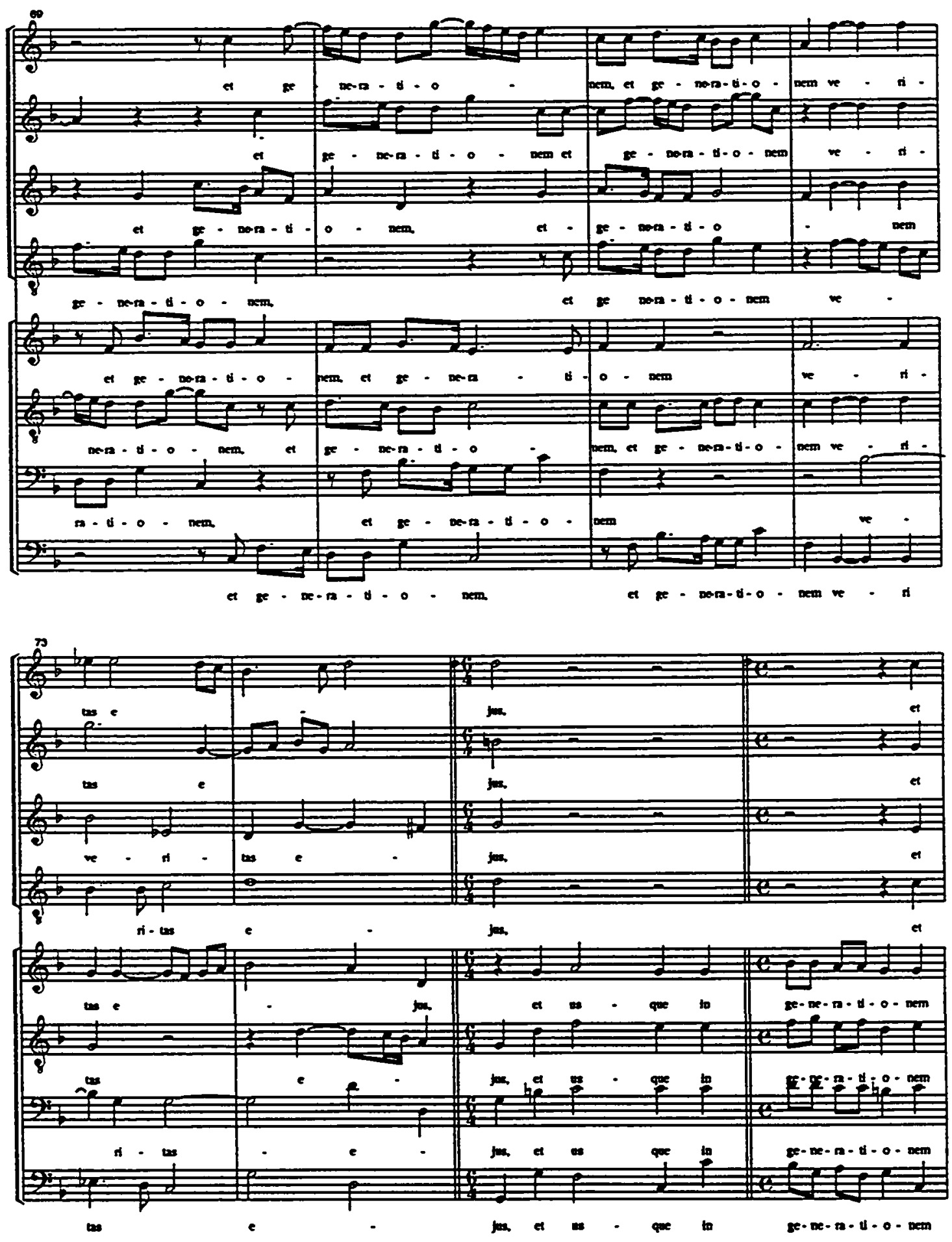

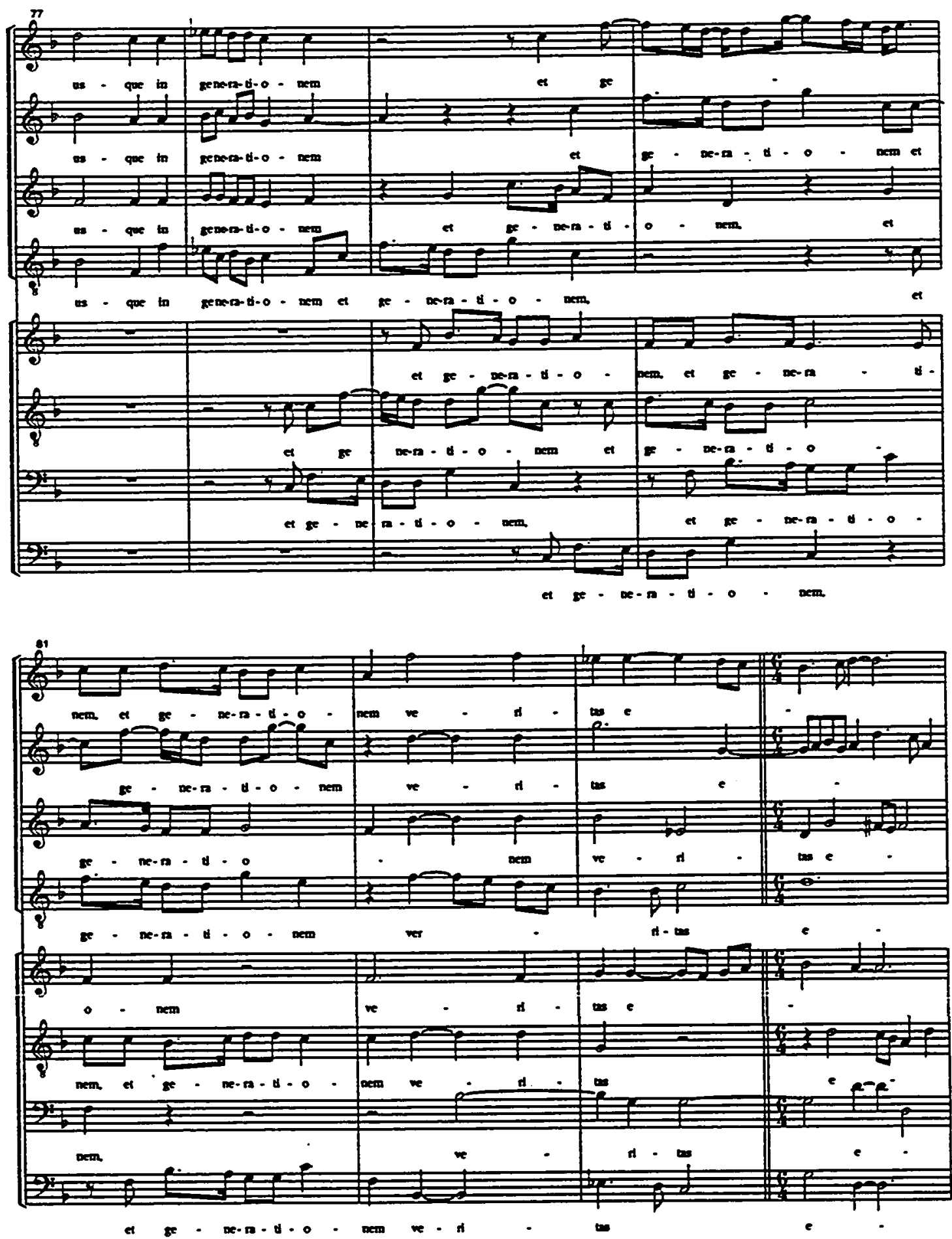


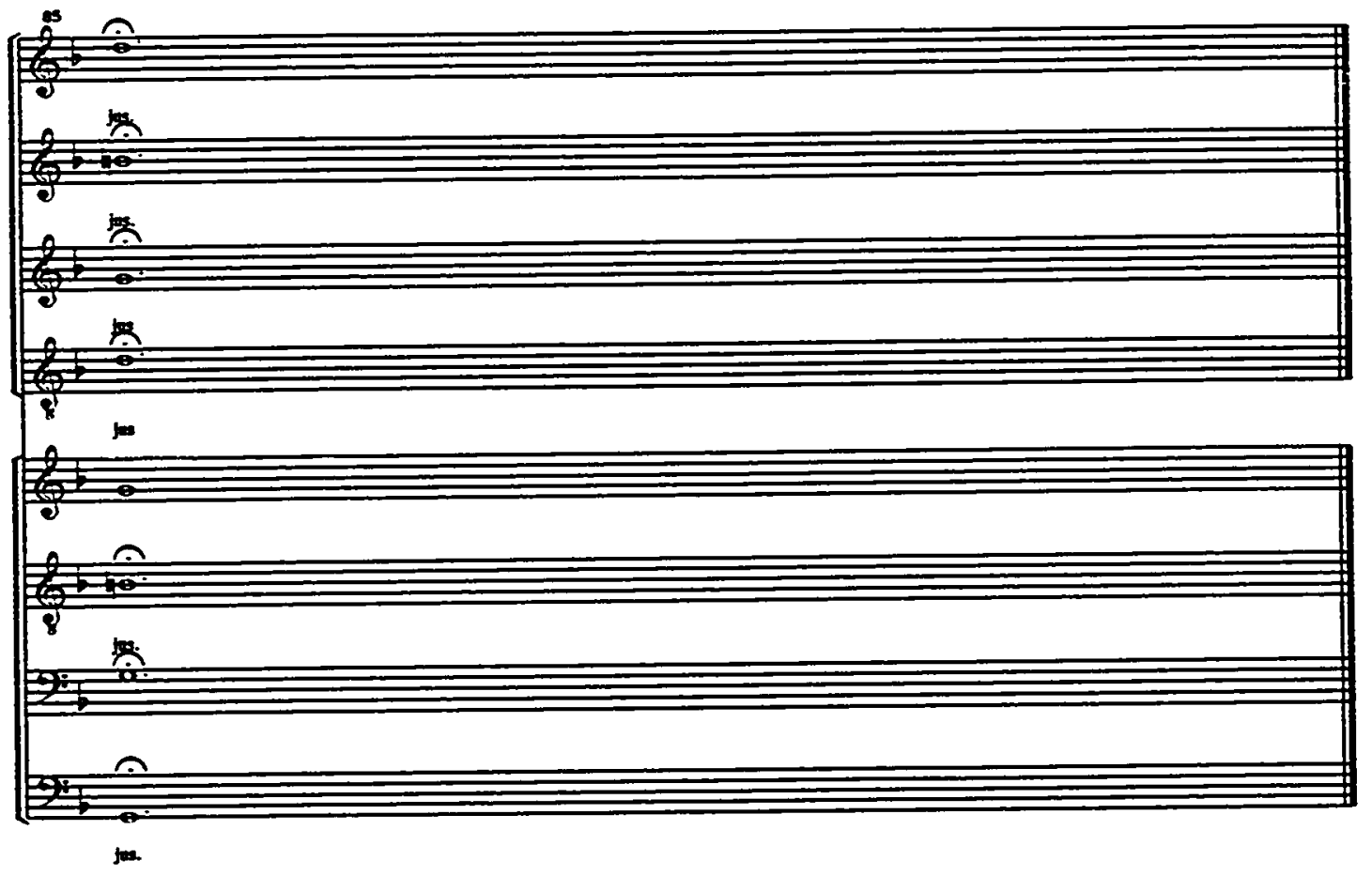



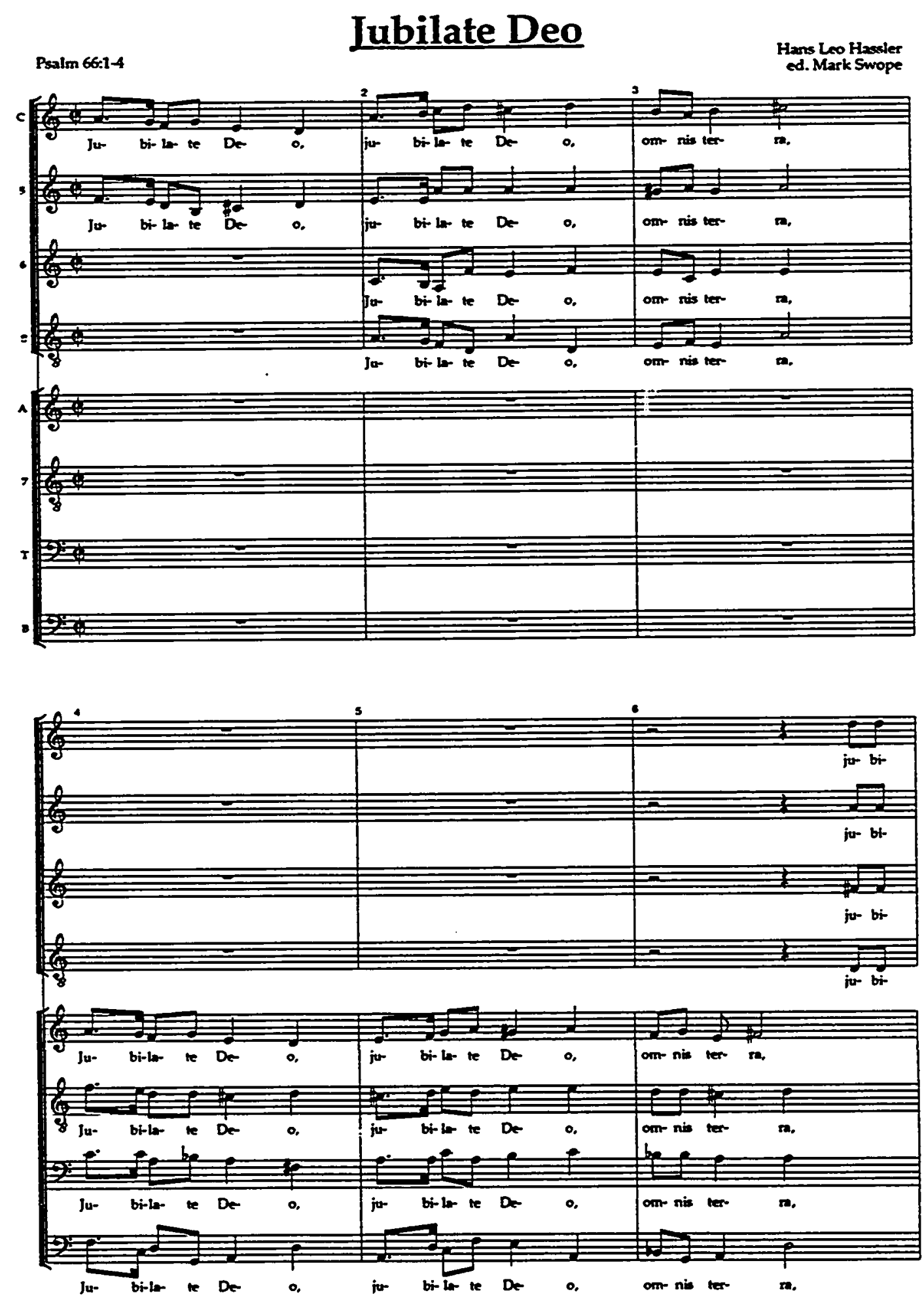

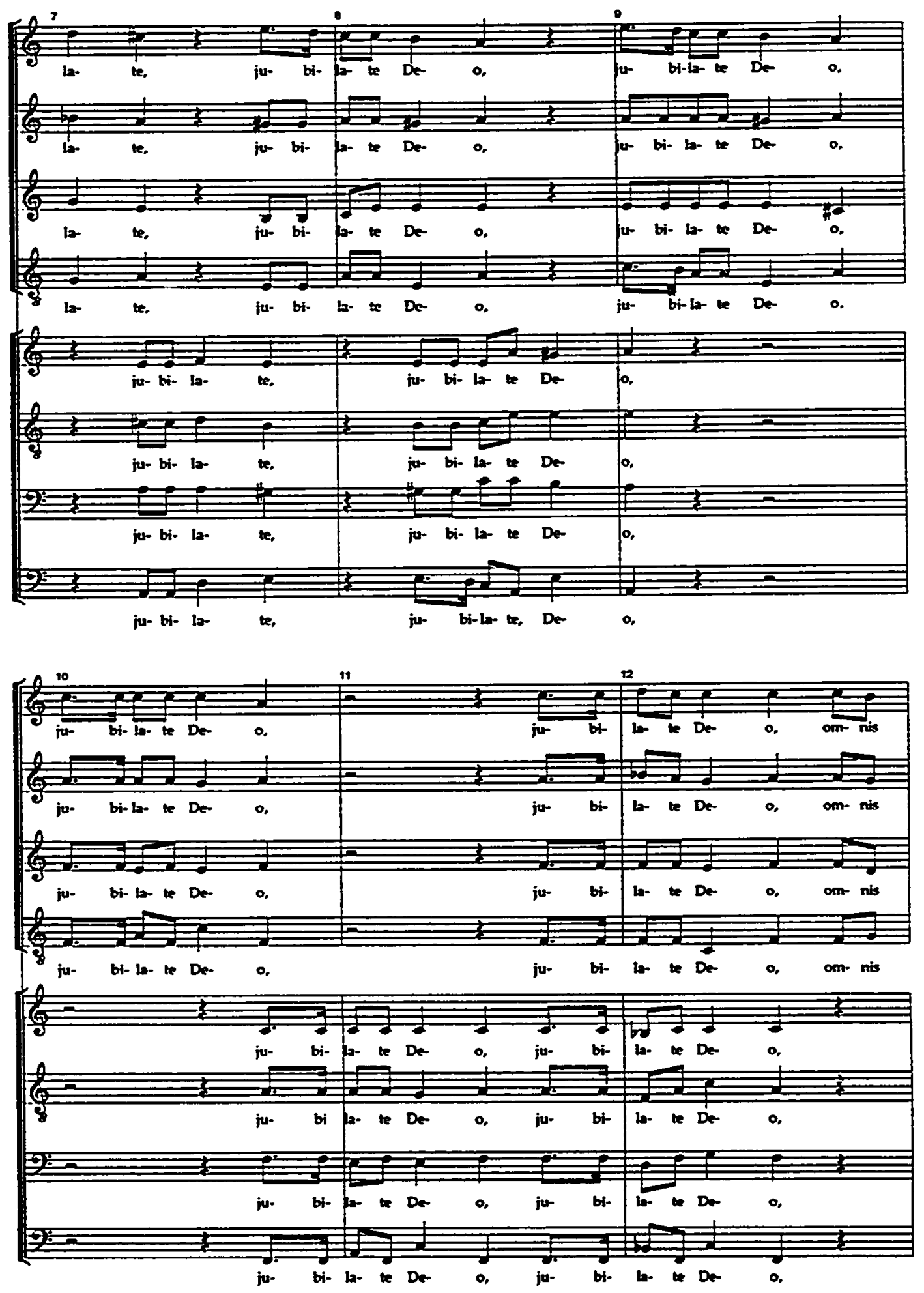

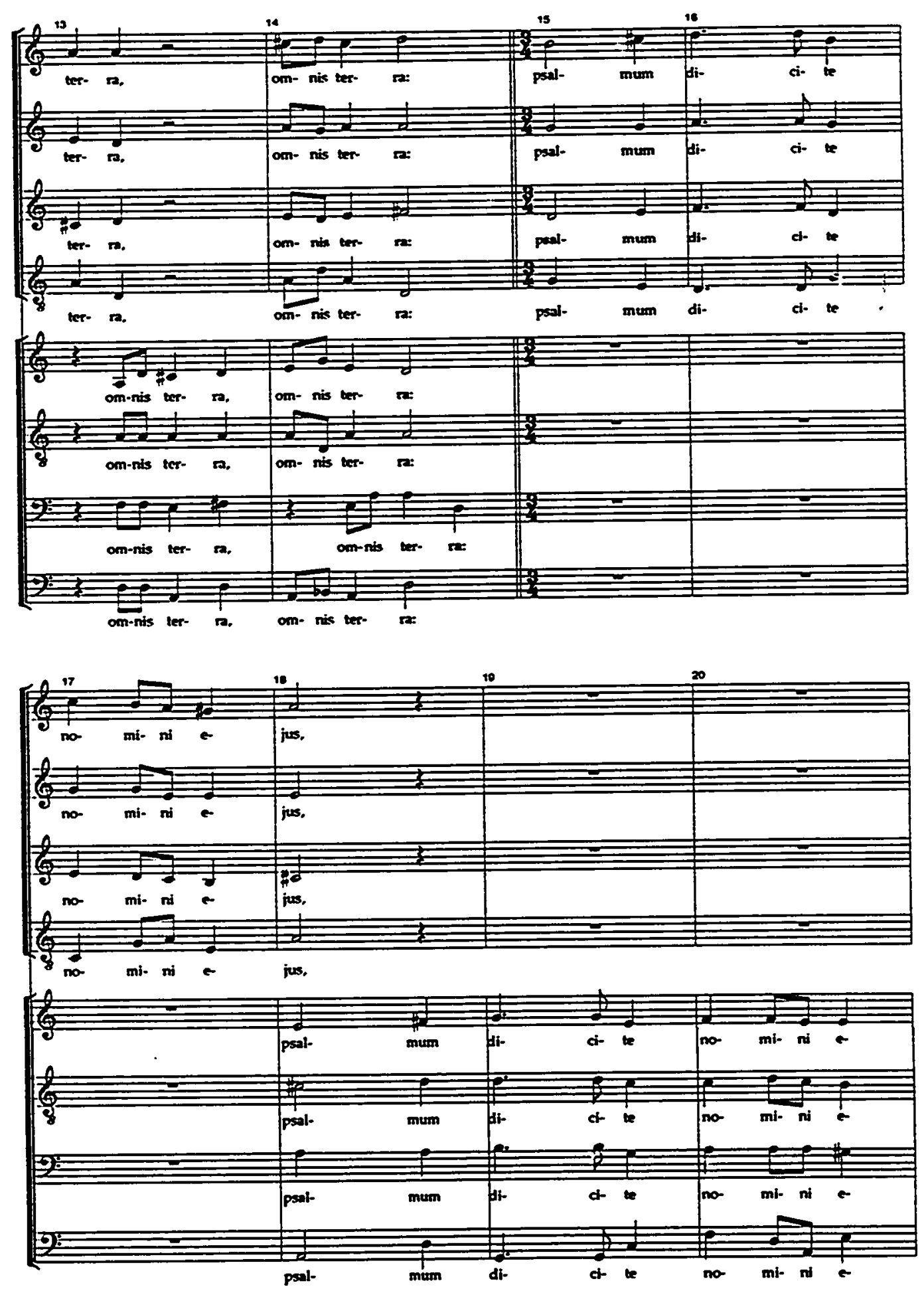

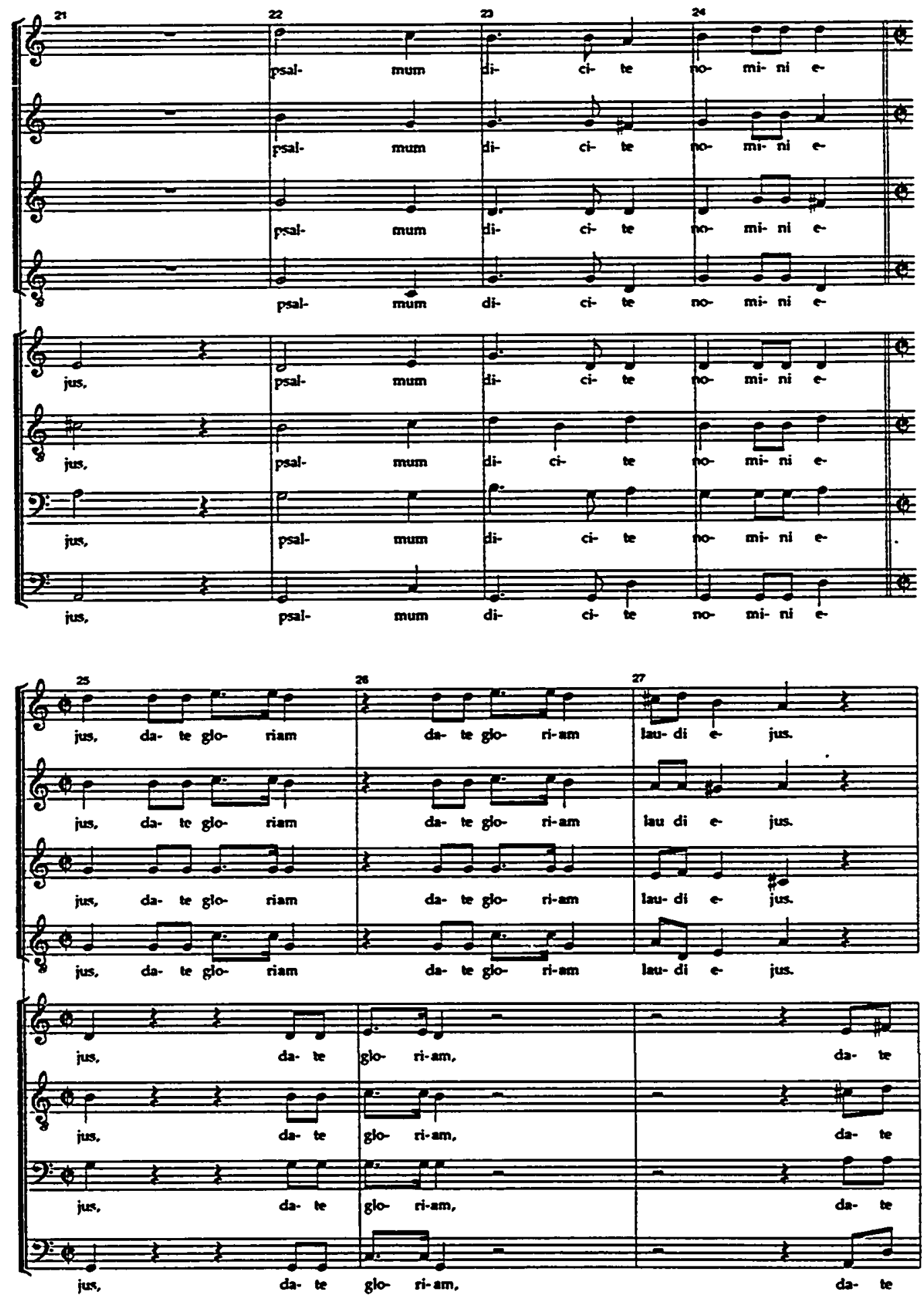

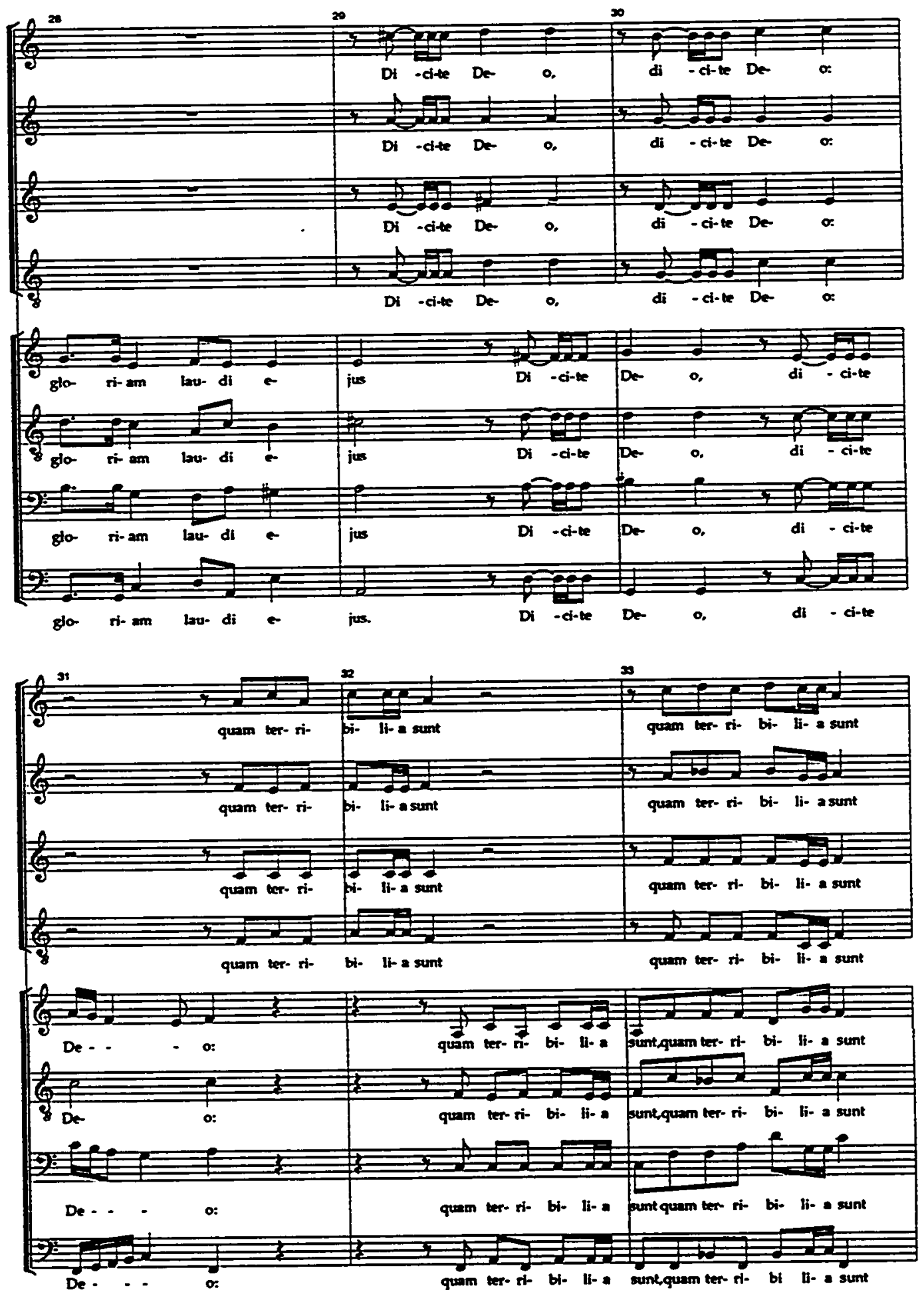

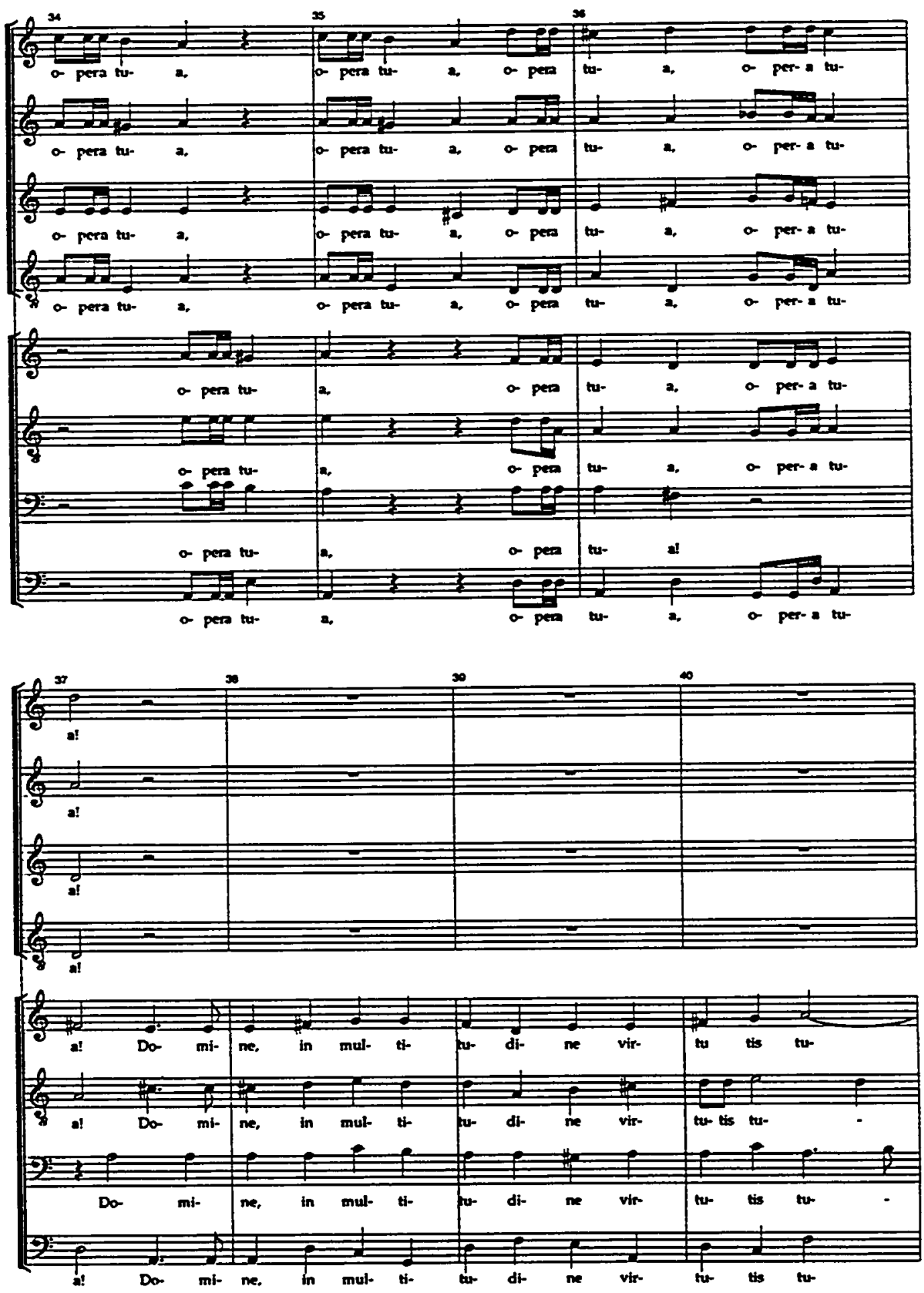

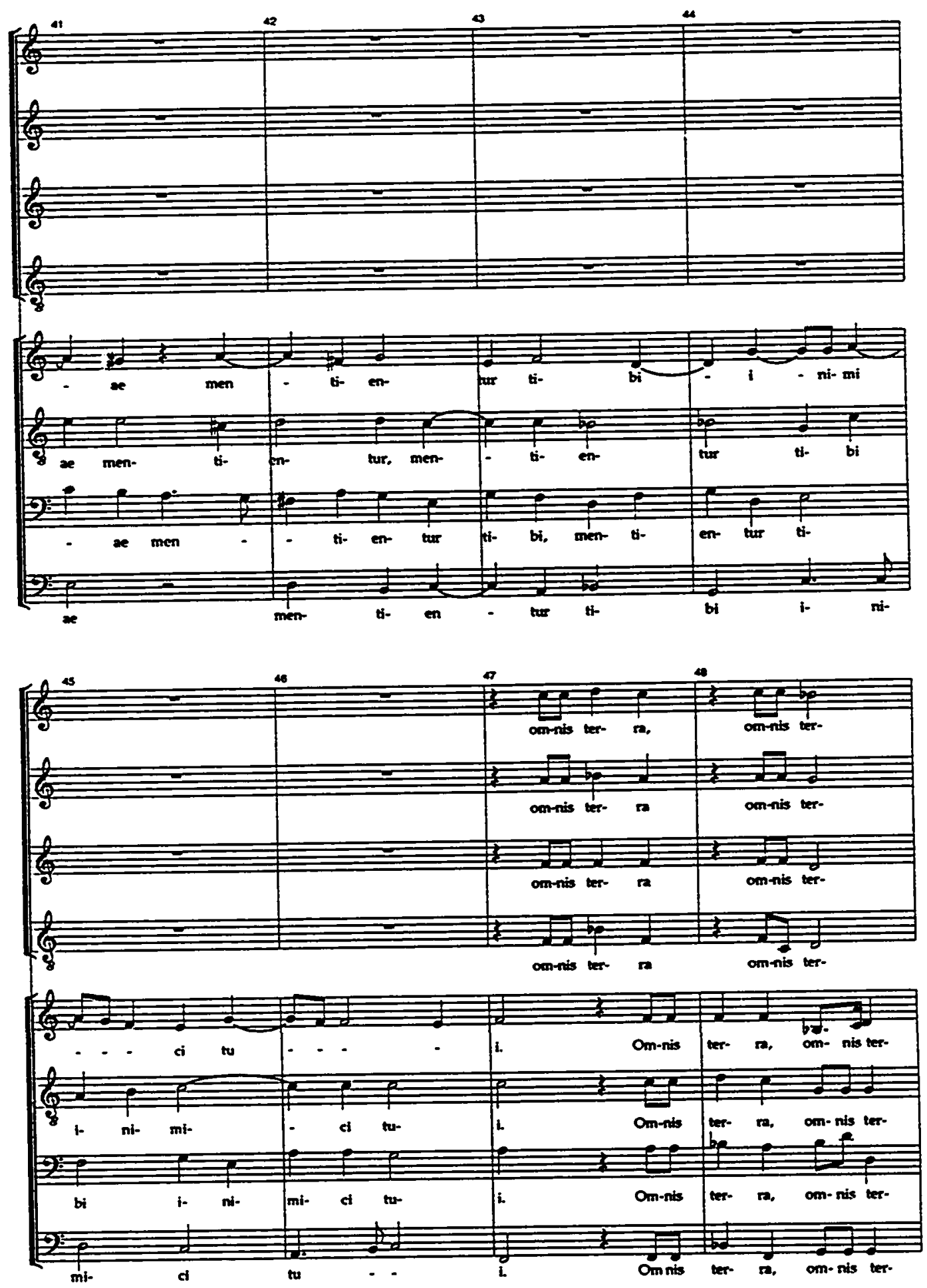

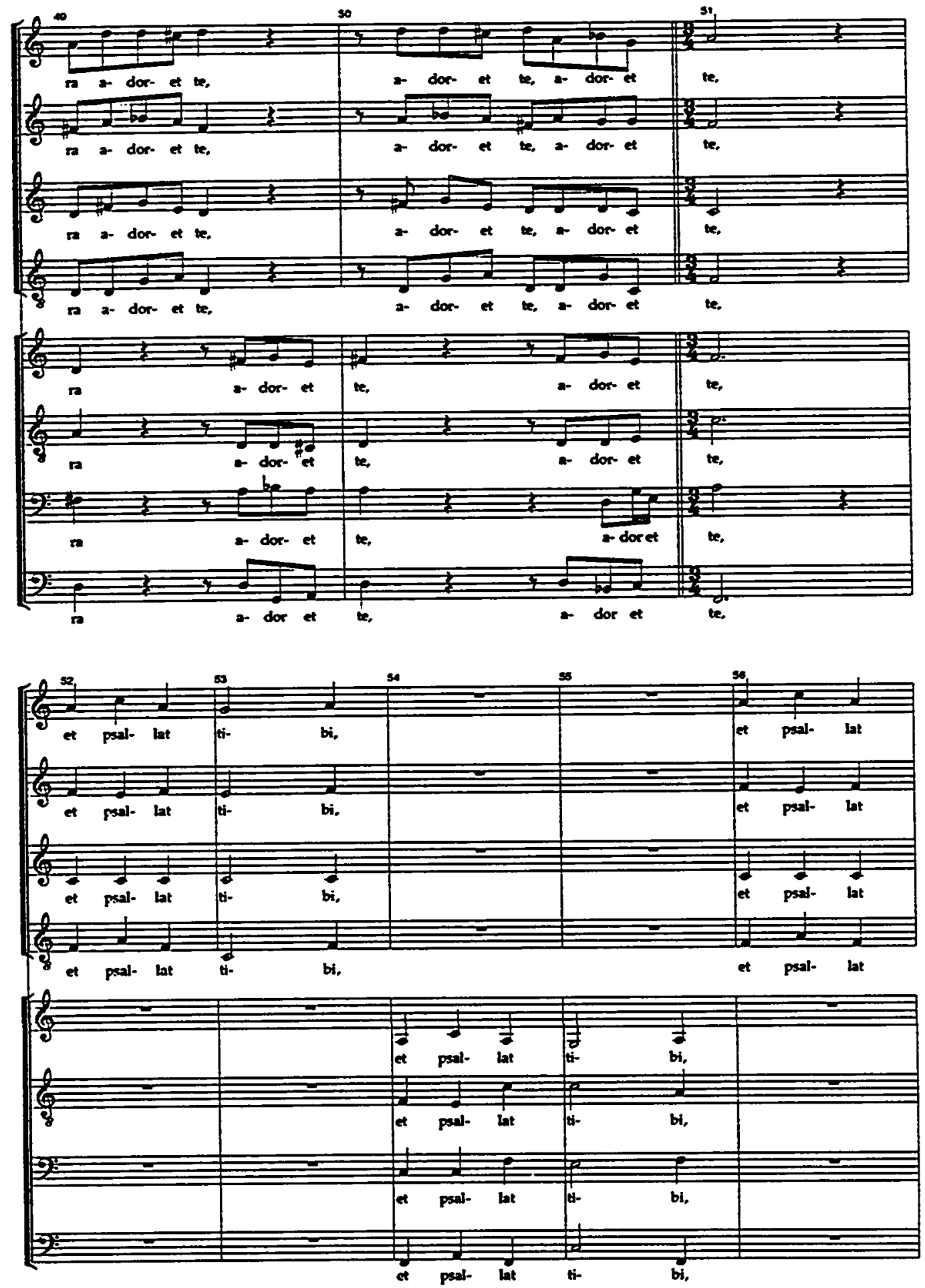

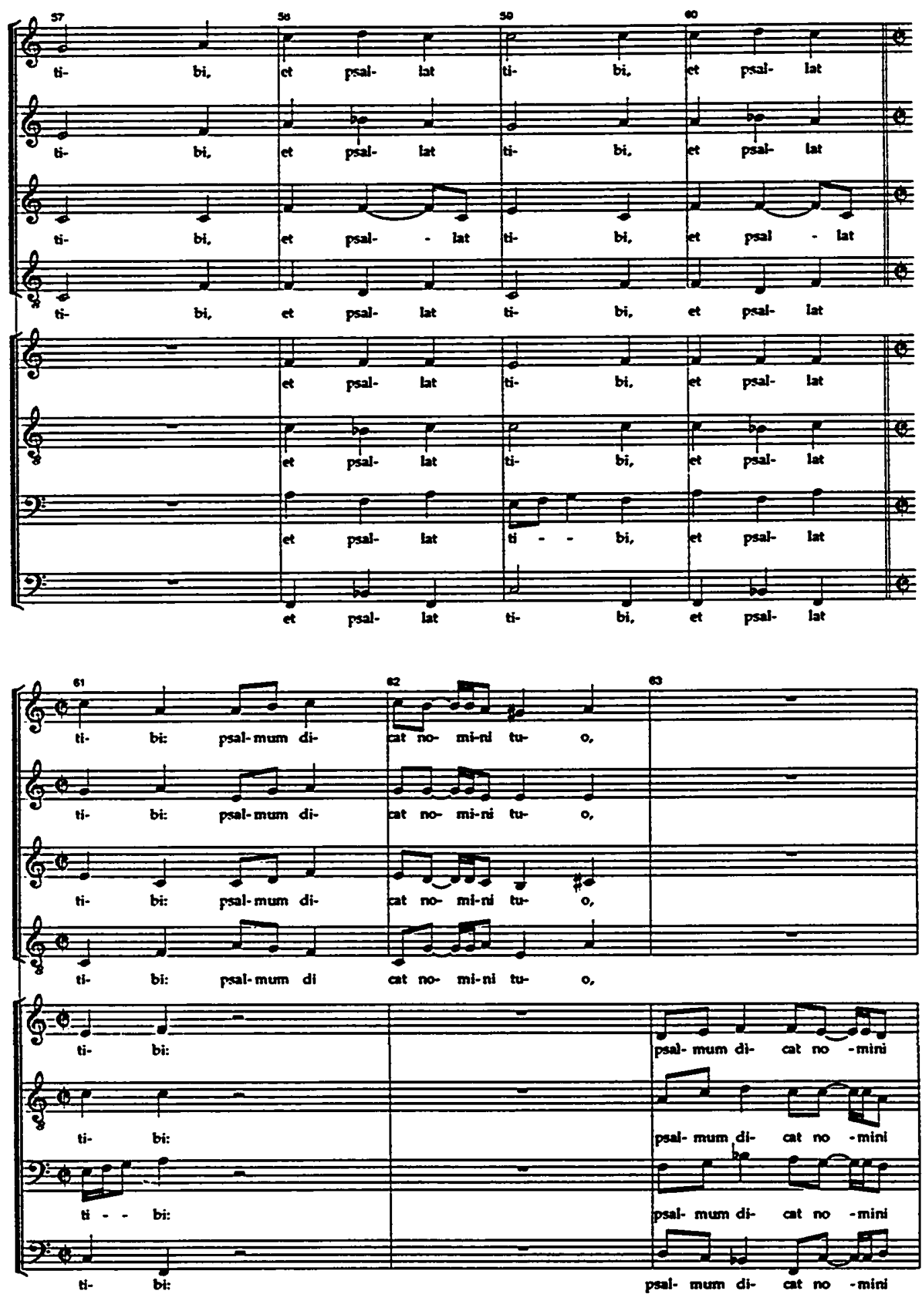

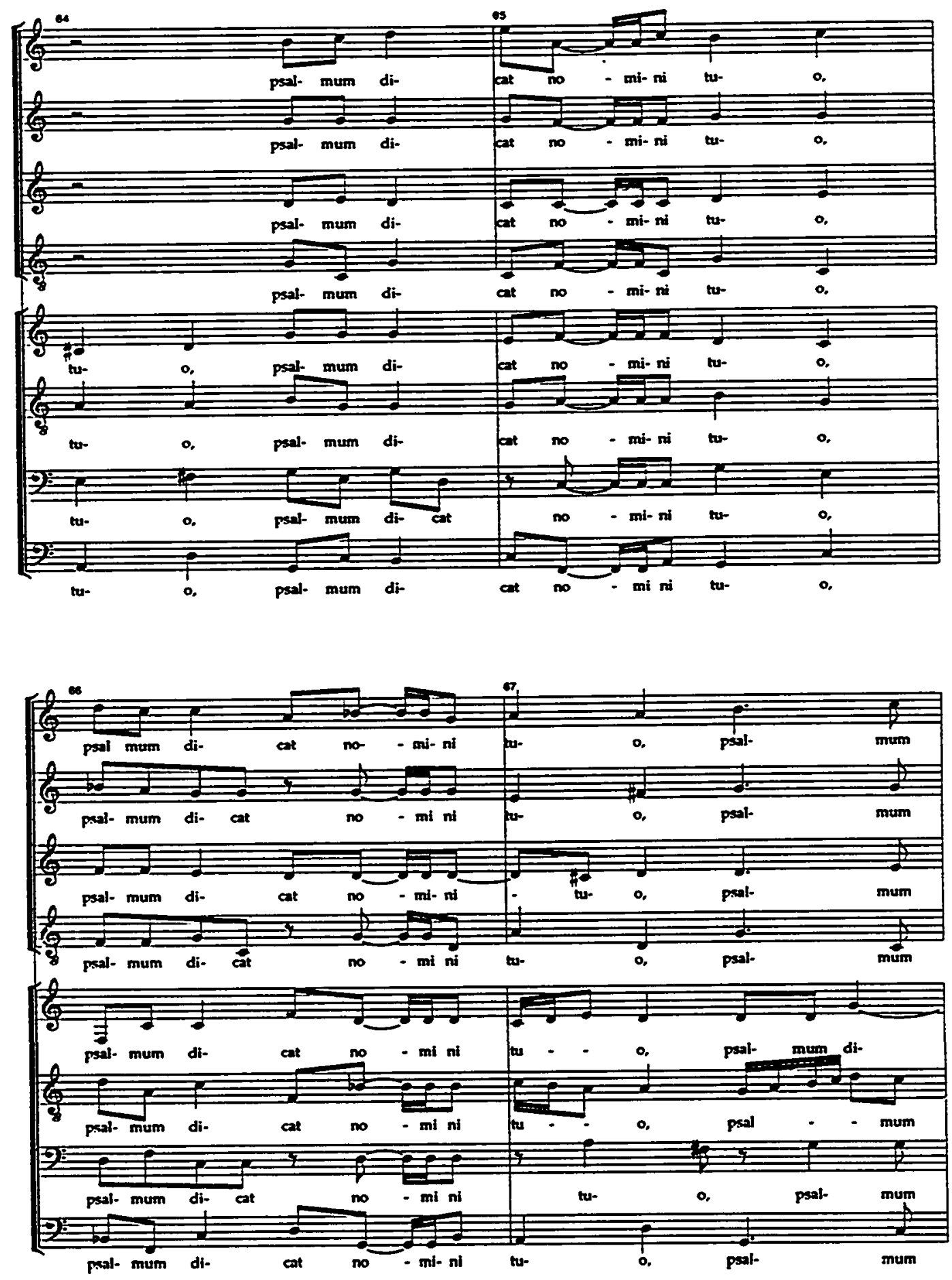

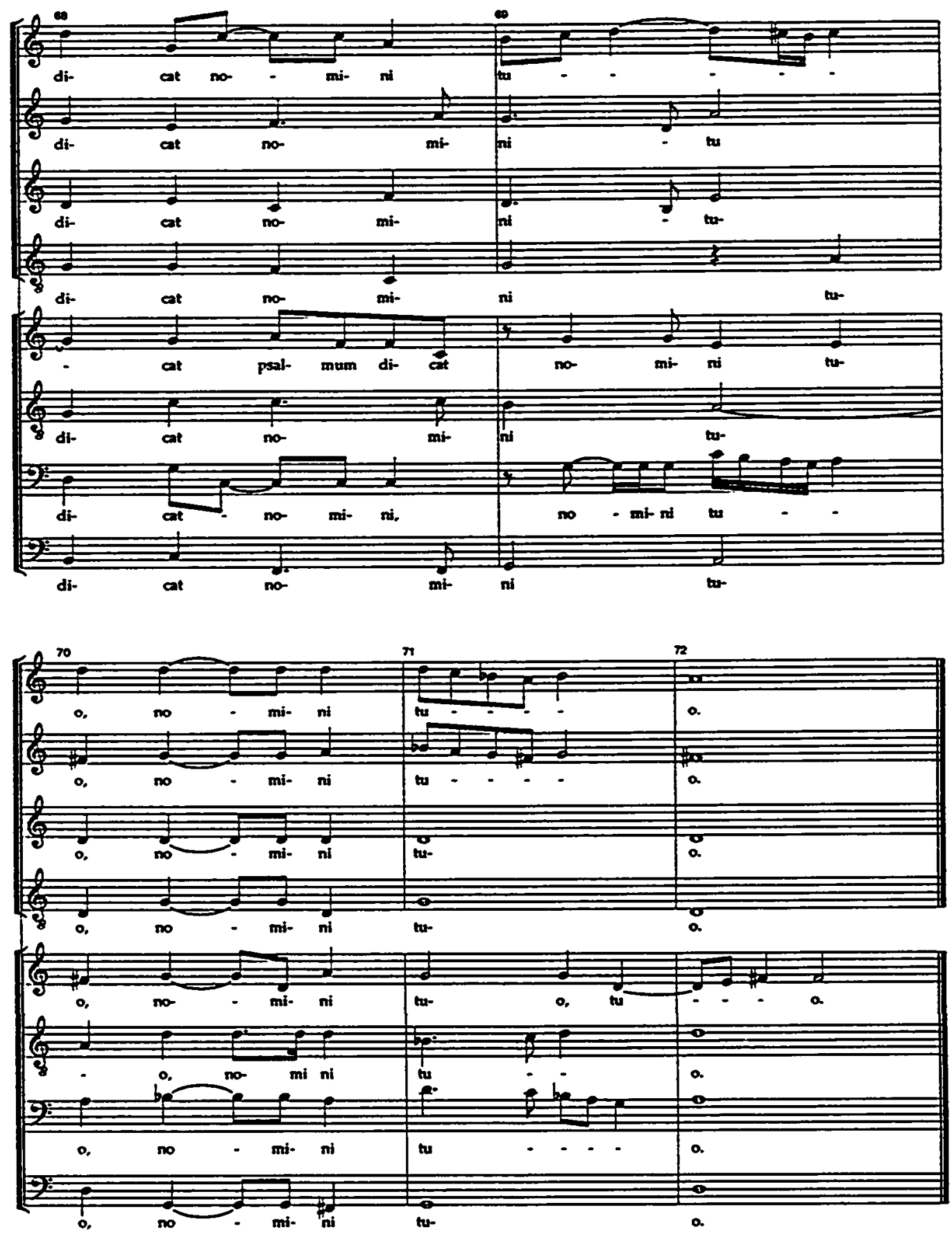